\title{
Diversity within Unity: Import Laws of Islamic Countries on Harām (Forbidden) Products
}

\author{
Raj Bhala* and Shannon B. Keating**
}

\begin{abstract}
How do Muslim countries treat importation of goods that Islamic Law (Sharì) considers Haram (forbidden), namely, alcoholic beverages and pork products? Why do they do so? What might Muslim countries do, in accordance with the rules of the General Agreement on Tariffs and Trade (GATT) and World Trade Organization (WTO), to alter their policies?

Based on painstaking empirical research of the WTO protocols of accession and schedules of tariff concessions of every Islamic country in the world, this article answers each of these three questions, which may be summarized in aggregate as "diversity within unity." All of the pertinent countries are members of both the WTO and Organization of Islamic Conference (OIC), and a majority of their populations profess adherence to one of the world's great faiths-Islam. Therein is their unity.
\end{abstract}

* http://en.wikipedia.org/wiki/Raj_Bhala Associate Dean for International and Comparative Law and Rice Distinguished Professor, The University of Kansas, School of Law, Green Hall, 1535 West 15th Street, Lawrence, KS 66045-7577 U.S.A. Tel. 785-864-9224. Fax. 785-864-5054. http://www.law.ku.edu. J.D., Harvard (1989); M.Sc., Oxford (1986); M.Sc., London School of Economics (1985); A.B., Duke (1984). Marshall Scholar (1984-86). Member, American Bar Association (ABA) Section of International Law, Council on Foreign Relations, Royal Society for Asian Affairs (England), Indian Society of International Law, All India Law Teachers Congress, Gateway House (Indian Council on Global Affairs), and Fellowship of Catholic Scholars. Admitted to practice, New York and D.C. . Author, treatise Modern GATT LAw (Thomson: Sweet \& Maxwell, 2nd ed., 2013, 2 volumes), textbook International Trade LaW (LexisNexis, 3rd ed. 2008, 4th ed. 2015, 2 volumes), reference Dictionary of International Trade LAW (LexisNexis, 2nd ed., 2012), textbook Understanding Islamic LaW (Sharīa) (LexisNexis 2011), and monograph Trade, Development, and Social Justice (Carolina Academic Press 2003).

** Legal Associate, New Markets Lab, 1100 17th Street, N.W., Suite 1000, Washington, D.C., U.S.A., skeating@newmarketslab.org. http://www.newmarketslab.org. J.D., University of Kansas (2013); B.A., Austin College (2005). Member, ABA Section of International Law, Washington International Trade Association (WITA), Women's Bar Association of the District of Columbia. Admitted to practice, Texas. The authors are grateful to Professor Joe Norton, James L. Walsh Distinguished Faculty Fellow and Professor of Financial Institutions Law, Southern Methodist University (SMU), Dedman School of Law, and formerly Sir John Lubbock Professor of Banking Law, University of London, for his generous support for and comments on this article. They also are thankful to Anton Cooray, Professor, City University London, City Law School; Marc Steinberg, Rupert and Lillian Radford Professor, SMU School of Law; and the student Editors and Staff of The International Lawyer, for their thoughtful assistance. 
But OIC-WTO Muslim majority countries are not all alike in their import measures on products the consumption of which the Sharì'a proscribes. Their diversity is in their trade policies.

Specifically, on the first question, strictly speaking, it is illegal under the Shari'a for Muslims to consume alcohol or pork. Therefore, the logical expectation is Muslim countries would invoke GATT Article XX(a), which is the famous public morality exception, and ban importation of alcohol and pork under this Article.

Yet, in fact, almost no Muslim country invokes the Article XX(a) exception. To the contrary, almost all Muslim countries allow importation of alcohol and pork and impose tariffs of varying degrees and forms on these products. In brief, Muslim countries tend to behave like non-Muslim ones (especially developing ones) in terms of their trade policies toward alcohol and pork. Thus, they may be classified into low, medium, and high-tariff countries and compared against aggregate statistics for non-Muslim ones. Doing so reveals the diversity of their import policies on Haram products.

Another way to put the first point is it appears the import rules of Muslim countries on alcohol and pork products are rather similar to those of non-Muslim countries. That is, Islamic countries tend to behave like everyone else in deciding the extent to which they impede market access for foreign alcoholic beverage and pork product exporters. Diversity in import policies transcends religious boundaries. Or, to put the point differently, we all worship the same God, but in different ways, and so too we are alike in our diverse trade policies to goods at which we look askance in that worship.

As to the second question, four tentative explanations may account for the similarity: a lack of legal capacity; tolerance toward religious minorities; moral relativism; and secularism. Legal capacity, specifically, a lack of expertise in GATT-WTO matters, is a well-known problem in developing and least-developed countries, regardless of whether they are Muslim. Tolerance is a part of Islamic history. As to moral relativism and secularism, these general trends in the Muslim and non-Muslim world have been the focus of attention of leading theologians and senior clergy, such as Pope Emeritus Benedict XVI and Pope Francis.

On the third question, Islamic countries may avail themselves of GATT flexibilities to modify their tariff concessions on alcohol and pork products, should they seek to do so. But they must be ready to pay compensation to, or even suffer trade retaliation from, interested WTO exporting countries. So, they have to make choices, trading off greater protection against adjustment payments.

A Statistical Annex (posted online at The International Lawyer) contains a full length Table of data and sources on which the discussion and analysis are based. Those statistics are summarized in the Tables in the Annex to this article.

In sum, this article is the first empirical analysis of the import rules of Muslim countries around the world on goods the consumption of which Islamic Law regards as forbidden. This study should not, however, be viewed as an effort to appraise whether those countries "practice what they preach." To the contrary, by bringing to light the diversity of their trade measures, their similarity to non-Muslim countries, and their future policy choices, this article reveals the richness of international trade law across the Islamic world.

\section{Diversity within Unity}

How do Muslim countries treat importation of goods that Islamic Law (Sharìa) considers Haram (forbidden), namely, alcoholic beverages and pork products? Why do they do

VOL. 47 , NO. 3 


\begin{tabular}{lllll}
\hline$\backslash$ joiprod01\productn $\backslash I \backslash I N L \backslash 47-3 \backslash I N L 302 . t x t$ & unknown & Seq: 3 & $15-M A Y-14$ & $12: 26$ \\
\hline
\end{tabular}

DIVERSITY WITHIN UNITY

so? What might Muslim countries do, in accordance with the rules of the General Agreement on Tariffs and Trade (GATT) and World Trade Organization (WTO), to alter their policies?

Based on painstaking empirical research of the WTO protocols of accession and schedules of tariff concessions of every Islamic country in the world, this article answers each of these three questions, which may be summarized in aggregate as "diversity within unity." All of the pertinent countries are members of both the WTO and Organization of Islamic Conference (OIC) and a majority of their populations profess adherence to one of the world's great faiths-Islam. Therein is their unity. But OIC-WTO Muslim majority countries are not all alike in their import measures on products the consumption of which the Sharìa proscribes. Their diversity is in their trade policies.

Specifically, on the first question, strictly speaking, it is illegal under the Shari' a for Muslims to consume alcohol or pork. ${ }^{1}$ Therefore, the logical expectation is Muslim countries would invoke GATT Article XX(a), which is the famous public morality exception, and ban importation of alcohol and pork under this Article. ${ }^{2}$

Yet, in fact, almost no Muslim country invokes the Article XX(a) exception. ${ }^{3}$ To the contrary, almost all Muslim countries allow importation of alcohol and pork and impose tariffs of varying degrees and forms on these products. ${ }^{4}$ In brief, Muslim countries tend to behave like non-Muslim ones (especially developing ones) in terms of their trade policies toward alcohol and pork. ${ }^{5}$ Thus, they may be classified into low, medium, and high-tariff countries and compared against aggregate statistics for non-Muslim ones. ${ }^{6}$ Doing so reveals the diversity of their import policies on Haram products. ${ }^{7}$

Another way to put the first point is it appears the import rules of Muslim countries on alcohol and pork products are rather similar to those of non-Muslim countries. ${ }^{8}$ That is, Islamic countries tend to behave like everyone else in deciding the extent to which they impede market access for foreign alcoholic beverage and pork product exporters. Diversity in import policies transcends religious boundaries. Or, to put the point differently, we all worship the same God, but in different ways, and so too we are alike in our diverse trade policies to goods at which we look askance in that worship.

As to the second question, four tentative explanations may account for the similarity: a lack of legal capacity; tolerance toward religious minorities; moral relativism; and secularism. Legal capacity, specifically a lack of expertise in GATT-WTO matters, is a well-

1. See Qur'An 5:90-91, translated in Translations of the Qur'an, Surah 5, Center FOr MusLim-Jewish ENGAGEMENT, http://www.usc.edu/org/cmje/religious-texts/quran/verses/005-qmt.php (last visited Mar. 19, 2014); QuR'AN 2:173, translated in Translations of the Qur'an, Surab 2, CENTER FOR MUSLIM-JEwISH ENGAGEMENT, http://www.usc.edu/org/cmje/religious-texts/quran/verses/002-qmt.php (last visited Mar. 19, 2014).

2. General Agreement on Tariffs and Trade art. XX(a), Oct. 30, 1947, 61 Stat. A-11, 55 U.N.T.S. 194 [hereinafter GATT].

3. See Raj Bhala, International Trade Law: Interdisciplinary Theory and Practice 339 (3d ed. 2008); see Table 5.

4. See Bhala, International Trade Law: Interdisciplinary Theory and Practice, supra note 3 , at 339 ; Table 5.

5. See Bhala, International Trade Law: Interdisciplinary Theory and Practice, supra note 3 , at 339; Table 5

6. See Tables.

7. See Tables.

8. See Tables.

WINTER 2013 
known problem in developing and least-developed countries, regardless of whether they are Muslim. ${ }^{9}$ Tolerance is a part of Islamic history. ${ }^{10}$ As to moral relativism and secularism, these general trends in the Muslim and non-Muslim world have been the focus of attention of leading theologians and senior clergy, such as Pope Emeritus Benedict XVI and Pope Francis. ${ }^{11}$

On the third question, Islamic countries may avail themselves of GATT flexibilities to modify their tariff concessions on alcohol and pork products, should they seek to do so. ${ }^{12}$ But they must be ready to pay compensation to, or even suffer trade retaliation from, interested WTO exporting countries. ${ }^{13}$ So, they have to make choices, trading off greater protection against adjustment payments. ${ }^{14}$

A Statistical Annex (posted online at The International Lawyer) contains a full length Table of data and sources on which the discussion and analysis are based. Those statistics are summarized in the Tables in the Annex to this article. ${ }^{15}$

In sum, this article is the first empirical analysis of the import rules of Muslim countries around the world on goods the consumption of which Islamic Law regards as forbidden. This study should not, however, be viewed as an effort to appraise whether those countries "practice what they preach." To the contrary, by bringing to light the diversity of their trade measures, their similarity to non-Muslim countries, and their future policy choices, this article reveals the richness of international trade law across the Islamic world.

\section{Review of GATT Article XX(a) Public Morality Exception}

In modern times, Article XX(a) is one of the most underappreciated exceptions to GATT obligations. ${ }^{16}$ There appear to be three reasons for this phenomenon. First, until the 2010 China Audio Visual Products case, there were no adopted GATT Panel or WTO Appellate Body Reports on this exception. ${ }^{17}$

Second, international trade law practitioners and scholars are in the grip of the classical and neo-classical free market economic paradigm. ${ }^{18}$ Trade is about wealth generation and maximization and not much more, except for a few obvious externalities (e.g., environ-

9. See Building Trade Capacity, WORLD Trade ORG., http://www.wto.org/english/tratop_e/devel_e/build_ tr_capa_e.htm (last visited Mar. 19, 2014).

10. See Sayyid Muhammad Rizvi, Religious Tolerance in Islam, AL-IsLAM, http://www.al-islam.org/articles/ religious-tolerance-islam-sayyid-muhammad-rizvi (last visited Mar. 19, 2014).

11. See Elise Italiano, A Holy Father's Intentional Approach, Catholic Voices USA (Nov. 6, 2013), http:// catholicvoicesusa.org/entry/a-holy-father-s-intentional-approach.

12. See GATT art. XXVIII.

13. See id.

14. See id.

15. See Tables.

16. GATT art. XX(a).

17. See Appellate Body Report, China-Measures Affecting Trading Rights and Distribution Services for Certain Publications and Audiovisual Entertainment Products, WT/DS363/AB/R (Dec. 21, 2009). This case is cited, discussed, and analyzed in Raj Bhala \& David A. Gantz, WTO Case Review 2010, 28 ArIz. J. InT'L \& Comp. L. 239, 260 (2011).

18. See generally, e.g., Chantal Thomas, Law and Neoclassical Economic Development in Theory and Practice: Toward an Institutional Critique of Institutionalism, 96 CoRNELl L. REv. 967 (2011).

VOL. 47 , NO. 3 


\begin{tabular}{lllll}
\hline$\backslash$ joiprod01\productn $\backslash I \backslash I N L \backslash 47-3 \backslash I N L 302 . t x t$ & unknown & Seq: 5 & $15-M A Y-14$ & $12: 26$ \\
\hline
\end{tabular}

DIVERSITY WITHIN UNITY

mental degradation or labor rights infringements) championed by vocal and well-financed interest groups. ${ }^{19}$

The third reason is an ideological disposition in many parts of the international legal academy toward so-called "value free" scholarship. The third reason is more sinister than the second. That is because the second reason bespeaks a narrow bent of mind but the third reason reflects intolerance. What "value free" really means is "politically correct liberal" values. ${ }^{20}$ Many non-specialists (the mainstream of America, as it were), and a minority in the international legal academy, see those "values" as so elastic and arrogant as to lack any principled ethical or religious core. ${ }^{21}$ Apparently aware of this opposition, there might be a preference to forget about, or ignore, Article XX(a). Mentioning it will only stir up another battle in the "Culture Wars" of modern times. Why not focus on the environmental exceptions in Article $\mathrm{XX}(\mathrm{b})$ and $(\mathrm{g})$, and possibly team up with liberallyinclined economists? 22

Yet, there it stands starkly, the first item the drafters of GATT put in the list of general exceptions. Article XX(a) states:

[s]ubject to the requirement that such measures are not applied in a manner which would constitute a means of arbitrary or unjustifiable discrimination between countries where the same conditions prevail, or a disguised restriction on international trade, nothing in this Agreement [i.e., GATT] shall be construed to prevent the adoption or enforcement by any contracting party of measures:

(a) necessary to protect public morals . . .23

This statement is nothing less than a choice among competing values. The drafters intoned public morality matters more than trade liberalization.

They did not define what "public morality" means. ${ }^{24}$ They left that thorny question to each contracting party (WTO Member) — and properly so. In practice, absent a dispute settlement case, the question is self-judging—or, it may be avoided (consciously or uncon-

19. See generally Understanding the WTO: Who We Are, WORLd Trade ORG., http://www.wto.org/english/ thewto_e/whatis_e/who_we_are_e.htm (last visited Mar. 19, 2014).

20. As just one example, in a book entitled Foundations of International Law and Politics, Yale Law School Dean Harold Hongju Koh and Professor Oona A. Hathaway collect and edit thirty-nine previously published works. Foundations of International Law and Politics (Oona A. Hathaway \& Harold Hongju Koh eds., 2005). Hardly two of them, put at the end (a co-authored piece by Professors Jack L. Goldsmith and Stephen D. Krasner, and a piece by Professor John Yoo) could be considered as well outside the liberal tradition. See Jack L. Goldsmith \& Stephen D. Krasner, The Limits of Idealism, in Foundations OF INTERNATIONAL LaW and Politics, supra, at 350; John Yoo, International Law and the War in Iraq, in FoundaTiONS OF INTERnAtional LAW AND Politics, supra, at 366. In 13 sections, there is a full section on liberal theory but none dedicated to "neo-conservative theory" (though one covers realism in international relations). Five pieces are from the works of the editors themselves. No works are from the considerable Catholic tradition on international relations (e.g., Papal Encyclicals and statements from the United States Conference of Catholic Bishops), nor from any other religious faith (e.g., for principles of international law in Buddhist doctrine see K. N. Jayatilleke, Dhamma, Man and Law (2000) and on Muslim doctrines concerning international law see The Islamic Law of Nations: Shaybani's Siyar (Majid Khadduri trans. 1966). See id.

21. See Foundations of International Law and Politics, supra note 20.

22. See GATT art. XX(b), XX(g).

23. GATT art. XX(a) (emphasis added).

24. See id.

WINTER 2013 


\begin{tabular}{lllll}
\hline \jciprod01\productn $\backslash I \backslash I N L \backslash 47-3 \backslash I N L 302 . t x t$ & unknown & Seq: 6 & 15-MAY-14 & $12: 26$ \\
\hline
\end{tabular}

sciously). But by inserting this exception, the drafters made clear from the outset there is a moral dimension to cross-border transactions.

That the drafters should take this position is not surprising. They had at least one major precedent on which to rely. The United States has had in its trade statutes a provision to take measures against importation necessary to protect public morals. ${ }^{25}$ This statute, 19 U.S.C. $\$ 1305$, from the Tariff Act of 1930, as amended, well pre-dates GATT. ${ }^{26}$ Without doubt, the American exception covers obscene materials, which includes pornographic films and printed matter and, particularly, child pornography. ${ }^{27}$ Few if any WTO Members would contest the inclusion of such materials in the ambit of Article XX(a).

But how each Member would delineate the obscene from the tolerable would vary from one Member to another. Would the exception permit an import ban on the music of certain "rap" artists, the lyrics of which include profanity? Such an inquiry is pertinent to Islamic countries, to the extent they may seek to align their import measures with Shari'a rules about products that are not to be indigested, namely alcohol and pork.

\section{Islamic Law (Sharïa) and Forbidden (Haram) Products}

\section{A. SHARİA DOCTRINE}

Drawing the line on importation of "immoral" merchandise under Article XX(a), if a WTO Member is inclined to do so, can be a challenge in a variety of contexts. Consider, for instance, the WTO accession negotiations of the Kingdom of Saudi Arabia, which culminated in the WTO approving the terms of entry for the Kingdom on December 11, 2005, at the Hong Kong Ministerial Conference. ${ }^{28}$ As an Islamic country, the Kingdom has had a long-standing ban-one that pre-dates the WTO accession of the Kingdomon imports of alcohol, pork, pork products, and pornography. ${ }^{29}$ Under Islamic Law (Sharia), consumption of these items is Haram to Muslims (with an exception, known as darūrāh, for necessity, which could be relevant in extreme circumstances). ${ }^{30}$

25. 19 U.S.C. $\$ 1305$ (2012).

26. Id.

27. See, e.g., United States v. Various Articles of Obscene Merch., 705 F.2d 41 (2d Cir. 1983) (discussing the constitutional tests for "obscenity" in the context of magazines imported from Germany).

28. Accessions: Saudi Arabia, WORLD Trade ORG., http://www.wto.org/english/thewto_e/acc_e/a1_arabie_ saoudite_e.htm (last visited Mar. 19, 2014). This illustration draws on Raj Bhala, Saudi Arabia, the WTO, and American Trade Law and Policy, 38 INT'L Law. 741, 790-92 (2004).

29. The Kingdom bans importation of seventy-three products, including the above-mentioned items, for religious reasons. See Daniel Pruzin, Saudis Flexible on Easing Investment Curbs During WTO Accession Talks, Report States, Int'l Trade Rep. (BNA) No. 21, at 288 (Feb. 12, 2004) (summarizing the banned imports). The other products, which are banned for various reasons (e.g., SPS protection, security concerns, social preferences, etc.) include animal fertilizer, asbestos, electronic greeting cards, mobile phones fitted with cameras, mobile phone chips, prepaid mobile phone cards, satellite Internet receivers, used tires, and video boosters. See id.

30. See Robin Allen, Saudis Blame "Unique Status" for Delays in foining WTO, Fin. Times (London), June 14, 2000, at 8 (quoting the Kingdom's former Minister of Commerce, Osama Jafar al-Faqih, as follows: "Under no circumstances will we allow the importation of pork, pork items or alcohol which are traditionally probibited according to our religion and our culture, nor will we allow access of audio-visuals which offend our public morals" (emphasis added)). For an overview of goods that are Haram, see JAMILA HusSAIN, IsLAMIC LAW and Society: An Introduction 114-16 (1999). On the darūrāh exception, see Joseph Schacht, An INTRODUCTION TO IsLamic LaW 84, 298 (1982).

VOL. 47 , NO. 3 


\begin{tabular}{lllll}
\hline$\backslash$ jciprod01\productn\I\INL\47-3\INL302.txt & unknown & Seq: 7 & $15-M A Y-14$ & $12: 26$ \\
\hline
\end{tabular}

DIVERSITY WITHIN UNITY

Never mind that some medicines contain alcohol, that some soaps have oil from pigs, or that some easily-available magazines contain "soft" pornography. ${ }^{31}$ The fact is, serious practice of the Sharì'a entails forswearing these products. ${ }^{32}$ Indeed, consumption of alcohol is among the most serious of crimes, a haqq Allab offense (i.e., a claim of God) and triggers severe punishment (a large number of lashes). ${ }^{33}$

\section{B. High Tariffs versus Import Bans}

Can this religious mortification and GATT obligations be squared and, if so, how? The starting point is a reminder there is no affirmative duty in multilateral trade law to import any product, least of all merchandise forbidden on religious grounds. ${ }^{34}$ Most (if not all) Muslim countries in the WTO-including two recently-acceded Arab Muslim Members, Jordan (in 2000) and Oman (also in 2000)—content themselves with applying a "prohibitive" tariff on alcohol, pork, and pork products, and with making use of the Article XX(a) exception. ${ }^{35}$ Aside from the possibility of garnering tariff revenues from an honest importer willing to pay the tariff, in certain circumstances, there is a certain rather surprising logic for this methodology.

Consider Algeria, which applied to join the GATT in June 1987 (and as of 2013 was not a WTO Member). ${ }^{36}$ It maintains a government monopoly on the production, sale, and export of wine and permits production of beer in both state-owned and private breweries. ${ }^{37}$ For alcoholic beverage imports, Algeria uses a system of reference prices. ${ }^{38}$ In 2003, the National People's Assembly sought enactment of an outright ban on these imports (via an amendment to the 2004 budget bill), despite the admonition of the Finance Minister that WTO accession negotiations would be jeopardized. ${ }^{39}$ In the Algerian context, the logic against the ban is it would be vulnerable to the charge of protectionism, i.e., the real

31. See generally Medications Containing Alcobol, SAN Diego St. U. DUI Program, http://www.sdsuduip. com/medications-containing-alcohol/ (last visited Mar. 19, 2014); Angel Flinn, Hidden Animal Fats, GeNTLE WORLD, http://gentleworld.org/hidden-animal-fats/ (last visited Mar. 19, 2014).

32. See QuR'An 5:90-91, translated in Translations of the Qur'an, Surah 5, Center For Muslim-Jewish ENGAGEMENT, http://www.usc.edu/org/cmje/religious-texts/quran/verses/005-qmt.php (last visited Mar. 19, 2014); QuR'An 2:173, translated in Translations of the Qur'an, Surah 2, Center for Muslim-Jewish ENGAGEMENT, http://www.usc.edu/org/cmje/religious-texts/quran/verses/002-qmt.php (last visited Mar. 19, 2014).

33. See Research Will Be Defining the Concept of Sharia Law, L. TEACHER, http://www.lawteacher.net/islamic-law/essays/research-will-be-defining-the-concept-of-sharia-law-islamic-law-essay.php (last visited Mar. 19, 2014).

34. See Allen, supra note 30, at 8 (citing WTO officials on this point).

35. See Press Release, World Trade Org. [WTO], Jordan Becomes 136th Member of the WTO (Apr. 11, 2000), http://www.wto.org/english/news_e/pres00_e/pr174_e.htm; Press Release, WTO, WTO's General Council Approves Accession of Oman (Oct. 10, 2000), http://www.wto.org/english/news_e/pres00_e/ pr194_e.htm; see Tables.

36. This discussion of the Algerian case is drawn from Lawrence Speer, Algerian Parliament's Approval of Total Ban on Alcohol Imports May Threaten WTO Talks, Int'l Trade Rep. (BNA) No. 20, at 1932 (Nov. 20, 2003). See also Daniel Pruzin, WTO Members Discuss Accession of Algeria, Lebanon; Iraq Explores Membership Process, Int'l Trade Rep. (BNA) No. 20, at 2079 (Dec. 18, 2003) (reporting the ban would expire at the end of 2004).

37. Speer, supra note 36.

38. See id.

39. See id.

WINTER 2013 
aim of the ban is to insulate the government monopoly on wine from foreign competitors and preserve lucrative tax revenues on beer sales.

This logic does not apply to the Kingdom. From a strict Islamic perspective, with respect to alcohol, pork, and pork products, this resolution is not satisfying. A tariff, even one set at a very high rate, is not a ban. It remains technically lawful to import the product, so long as the importer pays the tariff. That being so, it would be difficult for the Kingdom to proclaim to the Muslim World it "bans" alcohol, pork, and pork products in accordance with the Shari'a..$^{40}$ Moreover, there might well be importers in the Kingdom willing to pay, for example, a duty of 2,000 percent (or more) on alcoholic beverages from abroad. In brief, the tariff is not "prohibitive," but merely an expensive impediment. Worse yet, the more expensive an impediment is, i.e., the higher a duty rate, the greater the incentive to avoid it by smuggling alcohol (or pork or pork products). ${ }^{41}$ Put differently, an extraordinary tariff creates an extraordinary customs enforcement headache.

One resolution is for the Kingdom to accept a distinction between banning importation entirely and forbidding consumption by Muslims. Notwithstanding the practical problem of encouraging a "black market," a "prohibitive" tariff would not alter the gist of the religious precept, which is not to consume alcohol, pork, or pork products. ${ }^{42}$ The problem with this resolution is it may not be persuasive from a strict Islamic perspective, particularly one advocated by the dominant Wahhabi School in the Kingdom. From a Salafist (in effect, puritanical or extreme) vantage, any liberality could lead to a proverbial "slippery slope," i.e., the presence of foreign alcoholic beverages, pork, and pork products could encourage their consumption. ${ }^{43}$ Not surprisingly, different Islamic Members of the WTO have staked out different positions; Indonesia and Malaysia take a liberal view, permitting importation, while Brunei and Pakistan bar it. ${ }^{44}$ Brunei has a tiny exception for small amounts of beer or wine carried by individuals on their person when entering the Sultanate and declared to customs authorities, and such amounts must be consumed privately. ${ }^{45}$

As a leading voice in the Islamic World, the Kingdom chose the stricter line and argued alcohol, pork, and pork products are immoral articles within the meaning of Article

40. See Qur'An 5:90-91, translated in Translations of the Qur'an, Surab 5, Center For Muslim-Jewish ENGAGEMENT, http://www.usc.edu/org/cmje/religious-texts/quran/verses/005-qmt.php (last visited Mar. 19, 2014); Qur'An 2:173, translated in Translations of the Qur'an, Surab 2, Center for Muslim-Jewish ENGAGEMENT, http://www.usc.edu/org/cmje/religious-texts/quran/verses/002-qmt.php (last visited Mar. 19, 2014).

41. See, e.g., Saeed Kamali Dehghan, Iranian Pair Face Death Penalty after Third Alcohol Offence, GUARDIAN, June 25, 2012, at 18 .

42. See Qur'An 5:90-91, translated in Translations of the Qur'an, Surah 5, Center for Muslim-Jewish ENGAGEMENT, http://www.usc.edu/org/cmje/religious-texts/quran/verses/005-qmt.php (last visited Mar. 19, 2014); Qur'an 2:173, translated in Translations of the Qur'an, Surah 2, Center for Muslim-Jewish ENGAGEMENT, http://www.usc.edu/org/cmje/religious-texts/quran/verses/002-qmt.php (last visited Mar. 19, 2014).

43. See, e.g., NPR: Salafis in Egypt, WILSON CENTER (Jan. 29, 2013), http://www.wilsoncenter.org/islamists/article/npr-salafis-egypt.

44. See World Health Organization [WHO], Global Status Report: Alcohol Policy 178, 188 (2004); Harry Burns, Towards a Global Alcobol Policy: Current Directions, in Alcohol: Science, Policy, AND Public Health 395, 396 (Peter Boyle et al. eds., 2013); see Tables.

45. See Brunei Darussalam: Alcohol Advisory, TrIP Advisor (Sept. 16, 2010), http://www.tripadvisor.com/ Travel-g293937-c49385/Brunei-Darussalam:Alcohol.Advisory.html.

VOL. 47 , NO. 3 


\begin{tabular}{lllll}
\hline$\backslash$ joiprod01\productn $\backslash I \backslash I N L \backslash 47-3 \backslash I N L 302 . t x t$ & unknown & Seq: 9 & $15-M A Y-14$ & $12: 26$ \\
\hline
\end{tabular}

DIVERSITY WITHIN UNITY

XX(a). ${ }^{46}$ In other words, the Kingdom analogized these products to pornography. The below summarizes the Article $\mathrm{XX}(\mathrm{a})$ declarations made by the Kingdom, as well as those of the three other Islamic countries invoking the provision-Jordan, Oman, and Yemenin their WTO accession terms. ${ }^{47}$

Interestingly, then, the Kingdom is not the only Islamic country to draw the red line. Yemen, the newest Gulf Arab WTO Member-its accession terms were approved in December 2013 at the 9th WTO Ministerial Conference in Bali, Indonesia48_invoked Article $\mathrm{XX}(\mathrm{a})$ on haram products. ${ }^{49}$ But the Jordanian and Omani declarations are of a rather different ilk (as explained below).

Further, invocation is not the only way to draw that line. Pakistan and Brunei use the strategy of not binding their Most Favored Nation (MFN) duty rates on alcohol and (in Pakistan's case) certain pork products. ${ }^{50}$ Leaving a tariff line unbound may have the same effect as invoking Article XX(a), because it means any prohibition may be applied to block or impede market access.

For now, the point is not whether an analogy between Haram products like alcohol and pork, on the one hand, and Haram products like pornography, on the other hand, is objectively correct. Rather, the point is that in a world of roughly 1.5 billion followers of the Prophet Muhammad ${ }^{51}$ (Peace Be Upon Him (PBUH)), it is neither reasonable nor respectful to disregard the possible extension of Article XX(a) to religiously proscribed merchandise. ${ }^{52}$

46. See Bhala, International Trade Law: Interdisciplinary Theory and Practice, supra note 3, at 646 ; see Table 5 .

47. These declarations are contained in the Reports of the Working Party on the WTO Accession of each country, all of which are posted on the WTO website, http://www.wto.org, or http://gatt.stanford.edu/bin/ browse/docs. (1) For Jordan, they are in the main body of the Report. See Working Party on the Accession of Jordan, Report of the Working Party on the Accession of the Hashemite Kingdom of Jordan to the World Trade Organization, 20-22, tbl.5, WT/ACC/JOR/33, WT/MIN(99)/9 (Dec. 3, 1999) [hereinafter Fordan Accession Report]. (2) For Oman, they are in an Annex. See Working Party on the Accession of Oman, Report of the Working Party on the Accession of Oman to the World Trade Organization, 33, tbl.1, WT/ACC/OMN/26 (Sept. 28, 2000) [hereinafter Oman Accession Report]. (3) For the Kingdom, they are in Working Party on the Accession of the Kingdom of Saudi Arabia, Report of the Working Party on the Accession of the Kingdom of Saudi Arabia to the World Trade Organization, 114-16, annex F, WT/ACC/SAU/61 (Nov. 1, 2005) [hereinafter Saudi Arabia Accession Report].

48. WTO Agrees Membership Terms for Yemen, Paving Way for Formal Decision in Bali, World Trade Org. (Sept. 26, 2013), http://www.wto.org/english/news_e/news13_e/acc_yem_26sep13_e.htm; see Table 5.

49. See Working Party on the Accession of Yemen, Report of the Working Party on the Accession of Yemen to the World Trade Organization, 15, 80-81, tbl.12, WT/ACC/YEM/42 (Oct. 4, 2013) [hereinafter Yemen Accession Report].

50. See Tables.

51. Pew Forum on Religion \& Pub. Life, Mapping the Global Muslim Population (2009).

52. The United States may have done so as early as October 2000. See Daniel Pruzin, U.S., EU Push Saudis to Improve Market Access Offers for WTO Entry, INT'L Trade ReP. (BNA) No. 17, at 1654 (Oct. 26, 2000) (reporting "[t]he Saudis have also taken offense at what they see as efforts by some WTO members to force them to make commitments on the import of alcohol and pork products" (emphasis added)).

WINTER 2013 


\begin{tabular}{lllll}
\hline \\
ciprod01\productn $\backslash I \backslash I N L \backslash 47-3 \backslash I N L 302 . t x t$ & unknown & Seq: 10 & $15-M A Y-14$ & $12: 26$ \\
\hline
\end{tabular}

\section{Analytical Methodology}

\section{A. Summary Tables}

Manifestly, Tables 1 through 4 illustrate the diversity of approaches to Islamically-proscribed products taken by Muslim countries. ${ }^{53}$ The Tables, contained in the Annex, present data for the thirty-four countries that are WTO Members, are in the Organization of Islamic Conference (OIC), and have Muslim majority populations. ${ }^{54}$ The data are the Ordinary Customs Duties (OCD) bound under GATT Article II:1(b), first sentence, which are MFN tariff rates under Article I:1.55

Table 1 identifies OIC-WTO Muslim majority countries, and sets out the religious, economic, and educational make-up of the population in each one of them. ${ }^{56}$ This Table gives an introduction to these countries. ${ }^{57}$

Tables 2, 3, and 4 focus on these countries, because it is for them that tariff data are readily available from the WTO website, and emphasize the Muslim-majority Members among them. ${ }^{58}$ These Tables also include average values for Other Duties and Charges (ODC, discussed below). ${ }^{59}$ Their final rows contain and analyze aggregate import measure statistics. ${ }^{60}$

Table 2 summarizes the approaches of OIC-WTO Members with Muslim majority countries with respect to beer, while Table 3 does so with respect to wine and spirits. ${ }^{61} \mathrm{~A}$ sufficiently large number of these countries distinguish between beer, on the one hand, and wine and spirits, on the other hand, in their tariff policy, to warrant separate Tables. ${ }^{62}$ At the same time, none of the countries differentiate among types of beer, for instance, based on alcohol volume content such as 4.5 versus 10 percent. ${ }^{63}$ Connoisseurs know that beer is not just beer, but for bound MFN duty rates among these countries, it is. That said, a handful of countries distinguish cider (and perry) from beer, wine, and spirits. ${ }^{64}$

Anecdotally, as cider is more like beer than the other products, from the perspective of consumer tastes and preferences, it is included in Table 2 with beer. ${ }^{65}$ As for spirits, this

\footnotetext{
53. See Tables.

54. These Tables include Côte d'Ivoire, Guinea-Bissau, and Nigeria, the Muslim population of which is 38.6, 50, and 50 percent, respectively (as Table 1 lists). See Tables $1-4$. Technically, it might be more accurate to call them Muslim "predominant" countries, but for efficiency, they are dubbed "majority."

55. See Tables.

56. See Tables.

57. See Tables.

58. See Tables.

59. See Tables.

60. See Tables.

61. These Tables do not include tariff data for ethyl alcohol, which is used for a variety of commercial, as well as recreational, purposes. See generally Chemistry in its Element: Ethanol, Royal Soc'y OF CHEMISTRY, http://www.rsc.org/chemistryworld/podcast/CIIEcompounds/transcripts/ethanol.asp (last visited Mar. 19, 2014). That is because for use in drinking, it is not usually sold as such, but rather incorporated as an input into finished alcoholic beverages products, namely, distilled beverages such as whisky, vodka, and gin. See id. Those beverages already are covered in these Tables. See Tables. But Table 5 in the online Statistical Annex includes data for ethyl alcohol. See Table 5.

62. See Tables.

63. See Tables.

64. See Tables.

65. See Tables.
}

VOL. 47 , NO. 3 
rubric catches gin, geneva, rum, vermouth, vodka, whisky, and other hard liquors, as well as liqueurs. ${ }^{66}$ Most countries treat them along with wine, so Table 3 includes them. ${ }^{67}$ Of course, these Tables identify distinctions where appropriate. ${ }^{68}$

Table 4 summarizes the trade rules of OIC-WTO Muslim majority countries with respect to pork and pork products. ${ }^{69}$ As with alcoholic beverages, pork and pork products are a broad rubric, encompassing may tariff lines in the Harmonized System (HS). ${ }^{70}$ So, like alcoholic beverages, two or even more Tables could have been constructed. For example, delineations could have been made among pig fat, live swine, ham and sausages, and other merchandise. While some OIC-WTO Members do make such distinctions, others do not, and for present purposes, aggregating all such items as "pork products" is sufficient to illustrate the diversity of approaches among the countries. ${ }^{71}$

Finally, Table 5, which is presented in a Statistical Annex published online at The International Lawyer website, contains all of the disaggregated data used to construct the first three Tables, and in its footnotes cites the sources for those data. ${ }^{72}$ As its footnotes indicate, the sources (discussed herein below) are all easily accessible on the WTO website. ${ }^{73}$

Table 5 contains the raw statistics for all OIC countries, whether or not they have acceded to the WTO (or even lodged an accession application) and whether or not they have Muslim-majority populations. ${ }^{74}$ Therefore, it includes the following countries, which Tables 1 through 4 exclude and which are not yet WTO Members: Afghanistan, Algeria, Azerbaijan, Comoros, Iran, Kazakhstan, Lebanon, Libya, Somalia, Sudan, Syria, Turkmenistan, and Uzbekistan. ${ }^{75}$ And Table 5 includes Benin, Cameroon, Gabon, Guyana, Mozambique, Suriname, Togo, and Uganda, which Tables 1 through 4 exclude. ${ }^{76}$ These countries are in the OIC but do not have Muslim majority populations. ${ }^{77}$

The context for all Tables is the accession to the WTO as a Member (after January 1, 1995), or in some instances, accession to GATT as a contracting party (before January 1, 1995). ${ }^{78}$ In this context, three questions are asked. First, has the Muslim country invoked GATT Article $\mathrm{XX}(\mathrm{a})$ in its accession negotiations to ban importation of forbidden (Haram) products into its territory? Second, if it invoked Article XX(a), then for what products did it do so, i.e., what classes of merchandise did it define as "Haram?" Third, what patterns, if any, are evident from invocations of Article XX(a) across the Muslim world?

66. See Tables.

67. See Tables.

68. See Tables.

69. See Tables.

70. See Tables.

71. See Tables.

72. See Tables.

73. See Tables.

74. See Tables.

75. See Tables.

76. See Tables.

77. See Tables.

78. See Tables.

WINTER 2013 


\section{B. Three Judgment Calls}

Tariff schedules can be messy. So, in constructing Tables 2, 3, and 4, three judgment calls were necessary. First, how should a country be treated if it imposes on a Haram product an ODC pursuant to GATT Article II:1(b), second sentence, in addition to an OCD under Article II:1(a), first sentence?79 Should the categorization be based on the OCD, that is, the bound MFN rate, or the OCD plus the ODC?

On the one hand, if only the OCD is considered, then the protection may be understated, because OCDs can be considerable, even more than the ODC. On the other hand, if the OCD and ODC are used, then the protection may be overstated, because it is difficult to know if an ODC actually is imposed on every imported shipment. The risk of understatement was accepted, so the first method for categorization was used. In other words, classification of countries is based on the headline figure of the bound MFN rate. ${ }^{80}$ But, so as to be transparent, any ODC is listed parenthetically under the bound rate. ${ }^{81}$

It is important to recall a WTO Member need not impose its bound rate, i.e., it may apply a duty at any level up to the binding. ${ }^{82}$ While not a complete justification, this risk perhaps is offset in part by the fact that the Tables rely on bound MFN rates, not actually applied duties. ${ }^{83}$ Thus, the Tables overstate the actual protection against Haram products in a country that does not set its applied rate at the ceiling level. ${ }^{84}$

Second, how should a country be treated if it uses a specific duty, as distinct from an ad valorem tariff, on a Haram product?

Ideally, an AdValorem Equivalent (AVE) would be computed for the specific duty, and classification would follow easily. But computing AVEs is beyond the present scope. So, countries imposing a specific duty were classified based on a reasonable estimate of the significance of that duty. ${ }^{85}$ There was only one such country, Malaysia. ${ }^{86}$ It uses a specific duty denominated in local currency. ${ }^{87}$

Third, how should a country be treated if it has bound MFN tariffs on Haram products at different levels, depending on the product? Should it be classified based on its lowest bound rate, its highest one, or the average? Or, should the same country appear in multiple categories?

The latter approach is used. ${ }^{88}$ Doing so is interesting, as it reveals the dispersion of tariffs on forbidden products within a particular country. Indeed, that dispersion suggests the country may be motivated less by Islamic Law than by value-added steps in production when opting for different tariff bindings on different products-for example, live swine,

79. See GATT art. II:1(a)-(b).

80. See Tables.

81. See Tables.

82. See Raj Bhala, Modern GatT Law: A Treatise on the law and Political Economy of the General Agreement on Tariffs and Trade and Other World Trade Organisation AgreeMEnTs chs. 22-23 (2d ed. 2013) [hereinafter Bhala, Modern GATT Law].

83. See Tables.

84. See Tables.

85. See Tables.

86. See Tables.

87. See Tables.

88. See Tables.

VOL. 47, NO. 3 


\begin{tabular}{|c|c|c|c|}
\hline 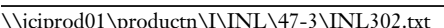 & unknown & Seg: 13 & 15-MAY-14 \\
\hline
\end{tabular}

DIVERSITY WITHIN UNITY

fresh or frozen carcasses, prepared or preserved ham, and sausages. Note, however, the Table does not reveal each product-those detailed data are in the annexed Table 5. ${ }^{89}$

Throughout, "Muslim" countries are defined as those holding membership in the Organization of the Islamic Conference (OIC). ${ }^{90}$ There are fifty-seven such countries. ${ }^{91}$ Essentially, they self-identify as such and they tend to do so based on having a population that is over 50 percent Muslim..$^{92}$ Table 5 (in the online Statistical Annex) organizes these countries according to region. ${ }^{93}$

\section{Status Categories and Unaddressed Questions}

To begin, of the full data set of fifty-seven OIC countries, thirty-four of them are WTO Members with Muslim majority populations. ${ }^{94}$ Listed in Table 1, this subset is organized according to the following three broad status categories:

(1) International Trade Law-

When did the country accede to the WTO?

(2) Religion-

To what extent is Islam the dominant (and indeed, state) religion of the country? Are there different branches of Islam (in particular, what is the Sunnite-Shi'ite breakdown) and non-Islamic faiths?

(3) Socio-economy-

As a snapshot of economic growth and development, respectively, what is the per capita Gross Domestic Product (GDP) and adult literacy rate of the country?

Tables 1 through 4 raise many fascinating linkage questions not addressed herein. ${ }^{95}$

For example, what is the relationship among the first three statuses? Are OIC countries that have acceded to the WTO characterized by large Muslim majorities and modern, developed economies? Looking at the Gulf Arab states, that seems to be the pattern; all the Gulf Cooperation Council (GCC) countries are WTO Members, whereas the poorer non-GCC countries, namely Iraq, are Observers. ${ }^{96}$ The membership of a non-GCC country, Yemen, was only recently approved in December 2013. ${ }^{97}$ Does such a pattern suggest the diversity observed in import policies has more to do with regional culture than with religion? Perhaps it is the culture predominant among countries within the same region that affects their decisions about how to treat international trade in alcohol and pork.

Such questions are not the focus of the discussion below. Rather, it is the relationship between the first three status categories, on the one hand, and the fourth one, on the other hand, that is of present interest. The key inquiry is what are the characteristics of OIC

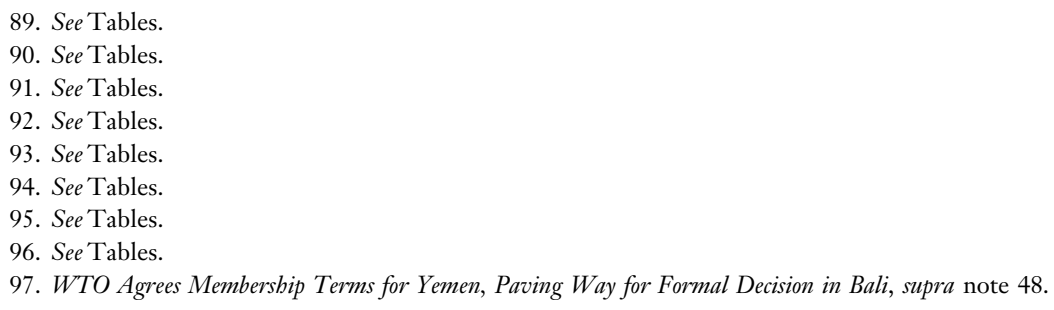


countries that have joined the WTO, have majority Muslim populations, and also invoked GATT Article XX(a), and what is the nature of their invocations?

\section{Seven Import Measure Classifications}

Tables 2, 3, and 4 slot OIC-WTO Members with Muslim majority populations into the following seven categories, which bespeak increasing degrees of protection: ${ }^{98}$

(1) Very Low Tariff Policy

These OIC-WTO Members have a bound MFN tariff of 0 to 29 percent on alcohol or pork. ${ }^{99}$ Conventionally, a tariff of below 10 percent would be considered "low," especially among developed countries, and below 5 percent essentially de minimis. 100 But a tariff of 11 to 29 percent, while not insignificant, certainly is not prohibitive. ${ }^{101}$ It still permits imported alcohol or pork market access, especially if there is no meaningful domestic-like product competition. ${ }^{102}$

(2) Low Tariff Policy

These OIC-WTO Members have a bound MFN tariff of 30 to 49 percent on alcohol or pork. ${ }^{103}$ A tariff of 30 to 49 percent is an impediment to the access of merchandise into the market of the importing country, as it is leads to a notable increase in the price of imported merchandise in the importing country (assuming the producer-exporter or importer do not absorb the tariff). ${ }^{104}$ But it still permits market access for those imports, alcohol, or pork, especially if there is no meaningful domestic-like product competition. ${ }^{105}$

(3) Medium Tariff Policy

OIC-WTO Members in this category have bound MFN duties on alcohol or pork between 50 and 99 percent. ${ }^{106}$ A tariff of this amount causes a noticeable retail price hike to imported merchandise, essentially, 1.5 times the non-tariffed price. ${ }^{107}$ It likely means average, middle class consumers would find alcohol or pork a luxury items, ones for special occasions. But it does not dissuade them altogether from consumption, and perhaps it is an unpleasant fact of consumption for wealthy buyers.

(4) High Tariff Policy

Any tariff over 100 percent is considered "high," simply because the retail price of the merchandise is at least doubled. ${ }^{108}$ OIC-WTO Members in this category may be sending either or both of two signals to prospective purchasers: consuming alcohol or pork is unlawful under the Sharìa for Muslims in the country, so a High Tariff operates to discourage buying the merchandise; but if either they or non-

\footnotetext{
98. See Tables.

99. See Tables.

100. See Tables.

101. See Tables.

102. See Tables.

103. See Tables.

104. See Tables.

105. See Tables.

106. See Tables.

107. See Tables.

108. See Tables.
}

VOL. 47, NO. 3 
Muslims insist on consuming it, then the government will collect a stiff "penalty." 109 Those who can afford the High Tariff, defined here as between 100 and 299 percent, are either high net worth (HNW) individuals or consumers who have saved for the product, which they may do insofar as they regard it as a luxury good for special occasions. ${ }^{110}$

(5) Prohibitive Tariff Policy

With a tariff of over 300 percent, it seems apparent a country is trying to deter importation of the product at issue. To be sure, HNW individuals can afford to consume goods on which duties such as 300 percent are levied. But the vast majority of consumers are priced out of the market for that good. In other words, from a tariff over 300 percent, it may be inferred that the point of trebling the price of the good is to block its importation. ${ }^{111}$

(6) Import Ban Policy

OIC-WTO Countries in this category have invoked GATT Article XX(a), banning importation of alcohol or pork as necessary to protect public morality as that morality is defined under Islamic Law. ${ }^{112}$ This position (as indicated above) comes closest to a pure, strict interpretation of Islamic principles on Haram products.

(7) Unbound Policy

OIC-WTO countries in this category have refused to bind their MFN duties on one or more Haram products. ${ }^{113}$

Via these categories, the diversity of import measures employed by the countries toward beer, wine and spirits, and pork, is apparent (as discussed below). ${ }^{114}$

\section{E. Preliminary Points}

The entire project begs the question, is WTO accession the only opportunity to invoke Article XX(a)? After all, Tables 1 through 4 focus on this context, i.e., successful invocations by a Muslim-majority OIC country when it negotiated for WTO Membership. ${ }^{115}$ That means the Tables leave aside unsuccessful invocations during the accession process; that is, times when an applicant tried but failed to invoke the public morality exception. ${ }^{116}$ There is no publicly available documentation of such instances, insofar as the negotiations were and remain confidential.

The Tables leave two further contexts in which a country might try to use GATT Article $\mathrm{XX}(\mathrm{a})$. The first is in a litigation posture, namely, a case brought against it under the WTO Understanding on Rules and Procedures Governing the Settlement of Disputes (Dispute Settlement Understanding, or DSU). ${ }^{117}$ China did so in the 2010 Audiovisual Products case,

109. See Tables.

110. See Tables.

111. See Tables.

112. See Tables.

113. See Tables.

114. See Tables.

115. See Tables.

116. See Tables.

117. Understanding on Rules and Procedures Governing the Settlement of Disputes, Apr. 15, 1994, Marrakesh Agreement Establishing the World Trade Organization, Annex 2, 1869 U.N.T.S. 401 [hereinafter DSU].

WINTER 2013 
but lost. ${ }^{118}$ (This case is discussed later.) The second is under the Trade Policy Review Mechanism (TPRM), which is established by Annex 3 to the Agreement Establishing the World Trade Organization (WTO Agreement). ${ }^{119}$ Possibly, a WTO Member criticized during the Review for a protectionist measure could claim an Article XX(a) justification. This interchange might be documented in the relevant Trade Policy Review Body (TPRB) Report. It would be necessary to check all such Reports for OIC countries that are in the WTO, a task for another time.

Another preliminary point about Tables 1 through 4 to consider is whether a Muslimmajority OIC-WTO Member country might have invoked an itemized exception under GATT Article XX, other than Paragraph (a), to block or impede imports of merchandise that are religiously proscribed under the Sharï'a. ${ }^{120}$ That is, might a country limit importation of a Haram product like alcohol as necessary to protect human health under Article $\mathrm{XX}(\mathrm{b})$ ? One such country, Tajikistan, subjects alcohol to an import license and quota restriction. ${ }^{121}$

But the general answer is no. The nature of Haram goods-alcohol, pork products, and pornography - seems to make justification easier under Paragraph (a) than (b). Aside from pornography, whether the other products, when consumed in moderation, pose a threat to human health is dubious. But whether any of them could be regarded as "immoral" by adherents to a particular faith is not in doubt, even if the faith-based justification is not shared by non-believers and indeed some adherents.

\section{F. Documentation}

Yet another preliminary point concerns the documentation for invocation of GATT Article $\mathrm{XX}(\mathrm{a})$. Ideally, any product for which an import ban or impediment is recorded should be listed in the Protocol of Accession, Working Party Report, or both, and presented in an Annex thereto. Then, such a product should be listed in the HS Schedule of Tariff Concessions, with a designation such as "P" for "Prohibited," i.e., importation of the good is prohibited. Saudi Arabia represents this ideal case. ${ }^{122}$

Accordingly, it ought not be necessary to consult the HS Schedule to find out which products, if any, a country has declared an Article XX(a). Yet, in some instances, the Protocol, Report, and Annexes thereto were silent as to invocation of Article $\mathrm{XX}(\mathrm{a}) .{ }^{123}$ Indeed, they were rather cursory and uninformative documents. In those cases, the HS Schedule had to be checked to see if there were any "P" items, and if mention (in the Head Notes to the Schedule) was made of Article XX(a). So, documentation underlying Article XX(a) invocations reflects both types of sources, that is, the Protocol, Report, and

\footnotetext{
118. See China-Measures Affecting Trading Rights and Distribution Services for Certain Publications and Audiovisual Entertainment Products, supra note 17.

119. Trade Policy Review Mechanism, Apr. 15, 1994, Marrakesh Agreement Establishing the World Trade Organization, Annex 3, 1869 U.N.T.S. 480.

120. See Tables.

121. See Working Party on the Accession of the Republic of Tajikistan, Report of the Working Party on the Accession of the Republic of Tajikistan, 95, WT/ACC/TJK/30 (Nov. 6, 2012).

122. See Table 5 .

123. See Table 5 .
}

VOL. 47 , NO. 3 


\begin{tabular}{lllll}
\hline$\backslash$ joiprod01\productn $\backslash I \backslash I N L \backslash 47-3 \backslash I N L 302 . t x t$ & unknown & Seq: 17 & $15-M A Y-14$ & $12: 26$ \\
\hline
\end{tabular}

DIVERSITY WITHIN UNITY

Annexes were checked and the Schedule was checked, too. ${ }^{124}$ Such Schedules are from the WTO website. ${ }^{125}$

\section{G. Problems with Tariff Schedules}

To say a Schedule of Concessions (typically called a "Tariff Schedule," or simply "Schedule") is checked raises two problems. First, Schedules generally do not state the justification for an import barrier on a product. ${ }^{126}$ Thus, looking only at a Schedule would be misleading, as it almost certainly would be erroneous to infer that the reason for every "P" in the Schedule was the country deemed the product "immoral." Only the Protocol, Report, or Annexes can provide the necessary guidance as to the justification. ${ }^{127}$

Second, which "Schedule" should be checked? In reality, a country may have more than one bound Schedule posted on the WTO website. Invariably, first, it will have a Schedule of Concessions annexed to the Marrakesh Protocol, i.e., its Uruguay Round Schedule, or if it acceded to the WTO after the Uruguay Round, a Schedule annexed to its Protocol of Accession. ${ }^{128}$ Second, it likely will have updated that Schedule, since the Uruguay Round or since its accession. ${ }^{129}$ The updates include clarifications, additions of details, and the like. ${ }^{130}$ They would not normally include revisions to bound MFN rates, unless the country renegotiated those rates under GATT Article XXVIII. ${ }^{131}$ But they are free to make a new, unilateral binding that is lower than what they previously conceded at the end of the Round or upon accession. ${ }^{132}$ (As explained below, such reductions occurred in a few cases.)

124. See Table 5.

125. The Schedule is available at Current Situation of Schedules of WTO Members, WorLd TRAdE ORG., http://www.wto.org/english/tratop_e/schedules_e/goods_schedules_table_e.htm (last visited Mar. 19, 2014), which is a Table listing all WTO Members. The fourth column of that Table concerns Goods Schedules annexed to the Marrakesh Protocol (i.e., the Uruguay Round Schedule), or to the Protocol of Accession. Each cell in the column contains a hyperlink to the Schedule of each Member. In contrast, the eighth and final column contains applied MFN rates, as well as updated bound Schedules, if the Member updated its Schedule since the Uruguay Round or post-Round accession. Table 1 relies on bound MFN rates, not actual applied rates. See Table 1. Ideally, if a country prohibits importation under GATT Article XX(a) of an article, then it would indicate that bar in both its bound and applied rate data. If it permits importation, but under a tariff, then an actual or prospective exporter and importer would care about the applied rate, but would look to the bound rate as the "worst case" scenario, as it is the ceiling level. For all countries that are both in the OIC and WTO, HS Schedules are in English, except for Burkina-Faso, Chad, Côte d'Ivoire, Djibouti, Gambia, Guinea, Guinea-Bissau, Mali, Mauritania, Morocco, Niger, Nigeria, Senegal, and Tunisia. See Current Situation of Schedules of WTO Members, supra. Obviously, the same techniques for reading and interpreting the English language Schedules were used for the French Schedules, with translation. Fortunately, the 2002 Schedules of these Francophone countries are available in English, and the English version was used, with cross-checking to the French version.

126. See Table 5.

127. See Table 5.

128. See Table 5; see generally Current Situation of Schedules of WTO Members, supra note 125.

129. See Current Situation of Schedules of WTO Members, supra note 125. The eighth and final column of the table lists when the WTO Member updated its Schedule.

130. See id.

131. See id.

132. See id.

WINTER 2013 
Accordingly, initially, data-presented in the online Statistical Annex, Table 5-were gleaned by using documents in their chronological order. ${ }^{133}$ That is, when the empirical investigation began, data were collected (and input into Table 5) based on the "first," or "first in time," bound Schedule, the one submitted at the end of the Uruguay Round or upon accession. ${ }^{134}$ Those moments were significant, because they were when a country achieved the status of GATT contracting party or WTO Member (possibly by converting from the former to the latter) or acceding after the birth of the WTO on January 1, 1995.

But in almost all instances, the Schedules associated with the Uruguay Round or Accession provide insufficient information on Haram goods-in particular, alcohol and pork products. Such "insufficiency" takes the form of incomplete data. For example, the Uruguay Round Schedule of Kuwait has many blank Excel sheets on which product descriptions, HS category codes, and numbers ought otherwise to appear. ${ }^{135}$

As another example, the Uruguay Round Schedules of Benin and Bahrain provide a tariff rate for all agricultural products, with only the product exceptions delineated. ${ }^{136}$ As still another example, the Uruguay Round Schedule for Turkey lists large aggregate produce groupings among which it is not possible to discern where pork products fall.137

Because of these data gaps, it was necessary to examine the "second," that is, "latest in time," Schedule. Doing so showed that the latest in time Schedule was the best source of data for almost all countries. Consequently, as the investigation progressed, the methodology changed from looking at the "first" Schedule first to looking at the "second" Schedule first. The result was use of 2002 Schedule data for all countries reflected in Tables 1 through 4. ${ }^{138}$ That is, data for all countries are from 2002 Schedules (with the exception of Tajikistan, which acceded in 2013, and Saudi Arabia, which acceded in 2005). ${ }^{139}$ Simply put, the data are drawn from the 2002 Schedules, with any necessary supplementations and exceptions noted. ${ }^{140}$

The sum and substance of the aforementioned points is that nailing down exactly which countries have invoked Article XX(a) to designate "P" items, and what those items are, is not a simple task based on full, transparent data. The Protocol, Report, Annexes, and Schedules need to be checked, and even then the results are less certain than ideal. But the best ought not to be the enemy of the good, hence Tables 1 through 4, and conclusions drawn from them, rely on what is, not what ought to be. ${ }^{141}$

Finally, note that Table 5 eschews redundancy by not listing unchanged data from different Schedules for a particular country. ${ }^{142}$ For example, for Burkina Faso Schedule XLVI (Uruguay Round) lists a bound MFN rate of 50 percent for products covered by Annex 1 of the WTO Agreement on Agriculture. ${ }^{143}$ This Annex covers HS Chapters 1 to

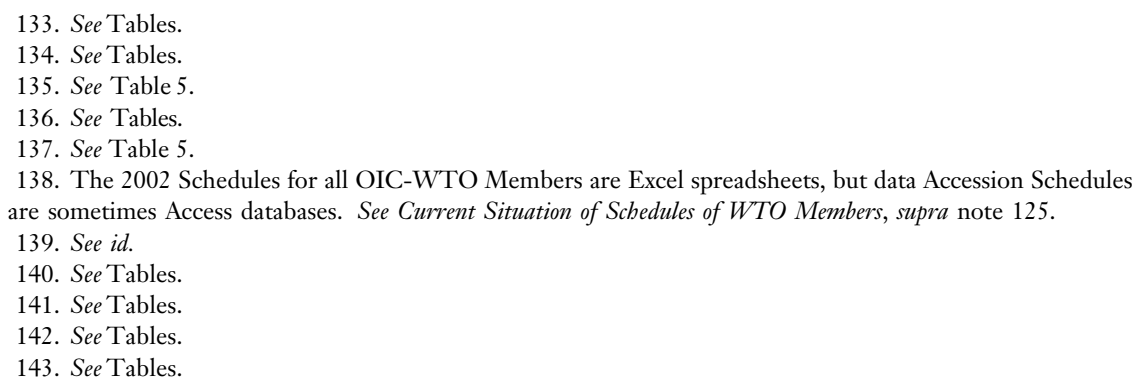

VOL. 47 , NO. 3 


\begin{tabular}{lllll}
\hline$\backslash$ joiprod01\productn $\backslash I \backslash I N L \backslash 47-3 \backslash I N L 302 . t x t$ & unknown & Seq: 19 & $15-M A Y-14$ & $12: 26$ \\
\hline
\end{tabular}

DIVERSITY WITHIN UNITY

24. ${ }^{144}$ Thus, it covers alcohol (which is in Chapter 22) and pork products (which are scattered through the first 16 HS Chapters). ${ }^{145}$ The 2002 Schedule for Burkina Faso lists precisely the same information. ${ }^{146}$ Therefore, it would be redundant to list the data from both the Uruguay Round and 2002 Schedules.

But where such data changed, the change is listed.147 That is, examining Schedules for a particular country across time allowed for checking whether a country may have decreased or increased its protections against Haram goods. If there was no change across time, then no special notation exists, i.e., stability in the trade policy of that country toward forbidden products logically can be inferred.148 But where a country did so (as with Egypt and Turkey, discussed below), Table 5 sets out the pertinent information. ${ }^{149} \mathrm{Natu}-$ rally, seeing either consistency or change is itself an interesting finding. ${ }^{150}$

\section{H. Services Exclusion}

Manifestly, an inquiry into morality and international trade ought to cover not only goods, but also services. There is a public morality exception in the General Agreement on Trade in Services (GATS). ${ }^{151}$ Its language, in Article XIV(a), tracks that of the GATT Article $\mathrm{XX}(\mathrm{a})$ exception. ${ }^{152}$ Islamic countries may, and indeed some do, have concerns about financial services that entail excessive risk (gharar) or interest (riba). ${ }^{153}$ Footnotes to Table 5 list such cases but do not pursue them through a detailed examination of the Schedules of Services Concessions. ${ }^{154}$

144. See Agreement on Agriculture, annex 1, Apr. 15, 1994, Marrakesh Agreement Establishing the World Trade Organization, Annex 1A, 1867 U.N.T.S. 410.

145. See id.

146. See Table 5.

147. See Table 5 .

148. See Tables.

149. See Table 5 .

150. Over time, WTO Members update their Schedules of Concessions. See Goods Schedules: Members' Commitments, World Trade OrG., http://www.wto.org/english/tratop_e/schedules_e/goods_schedules_e.htm (last visited Mar. 19, 2014). Thus, a new time series analysis that highlights consistencies and changes in Schedules is always possible, assuming new data are readily available on a reliable website. For instance, for some OIC-WTO Members, 2007 bound tariff rate data may be available. See Current Situation of Schedules of WTO Members, supra note 125. But as of this writing, such data were not readily available for all of these Members on the WTO website.

151. General Agreement on Trade in Services art. XIV, Apr. 15, 1994, Marrakesh Agreement Establishing the World Trade Organization, Annex 1B, 1869 U.N.T.S. 183 [hereinafter GATS].

152. See id.

153. Sarah Alghamdi, The Saudi T'awuni Insurance Model: Concerns about Compatibility with Islamic Law in Accommodating "Risk", at 2 (2013) (unpublished Masters of Law thesis, University of Toronto, available at https://tspace.library.utoronto.ca/bitstream/1807/35106/5/Alghamdi_Sarah_S_201303_Masters_Thesis.pdf.

154. See Table 5 .

WINTER 2013 


\section{Analysis of Import Measures on Haram Products}

\section{A. Article XX(A) UnCommonly InVOKed}

In the summary Tables, what patterns emerge as to the relationship for Muslim majority OIC-WTO Members and their invocations of GATT Article XX(a)? The first, and perhaps most surprising, finding is that only a minority of those Members expressly invoked GATT Article XX(a) to ban importation of Haram goods. ${ }^{155}$ That is evident from an oftused indication in Table 5 in the online Statistical Annex, such as "Neither the Protocol of Accession nor Working Party Report states an invocation of Article XX(a)."156 Indeed, the only OIC-WTO Member countries that declared Article XX(a) exceptions in their Protocols of Accession were Jordan, Oman, Yemen, and Saudi Arabia. ${ }^{157}$

Put simply, as a matter of modern International Trade Law, the majority of Islamic countries treat these forbidden products like any other merchandise in global trade. ${ }^{158}$ Notwithstanding orthodox precepts of the Shari' a, most OIC-WTO countries generally do not ban importation of alcohol or pork products. ${ }^{159}$ Rather, they impose the most conventional of protections against them-tariff barriers. ${ }^{160}$ Typically, the bound MFN duty rates are significant, sometimes quite stiff, and occasionally prohibitive. ${ }^{161}$

It would be unfair, erroneous, and even slanderous to infer from this legal fact that some Muslims behave hypocritically. Like adherents to any other great faith, some Muslims are devout, others are secular, still others in between, and all are on a spiritual journey. ${ }^{162}$ Absolutely no inference whatsoever should be drawn from international trade rules of Islamic countries about the piety of Muslims as individuals or the sincerity of Muslim communities in OIC-Member countries about the practice of Islam.

What can be said is that as a practical legal matter, most Islamic countries have not availed themselves of the GATT Article XX(a) exception so as to ban importation of alcohol or pork products. ${ }^{163}$ The obvious next question is, "Why?," that is "Why do so many Islamic countries in their tariff schedules allow importation of Haram and non-Haram goods?" Like the Islamic world itself, and like the theory and practice of the Shar $\vec{\imath} a$, there

155. See Table 5 .

156. See Table 5 .

157. See Table 5 .

158. Transactions: Haraam Transactions, The Official Website of His Eminence Grand Ayatollah aL-SAYYID 'Ali AL-HuSAYNi AL-SiSTANI, http://www.sistani.org/english/book/48/2314/ (last visited Mar. 19, 2014).

159. See, e.g., Tariff Information by Country, Foreign Aff. Trade \& Dev. Can. (Mar. 5, 2014), http://www. international.gc.ca/trade-agreements-accords-commerciaux/topics-domaines/goods-produits/ac_link.aspx? lang=eng; see Table 5 .

160. See, e.g., Tariff Information by Country, supra note 159; see Table 5.

161. Tariff Information by Country, supra note 159. They also may impose non-tariff barriers, such as import licensing schemes, but those types of restrictions are not reflected in Tariff Schedules, and not discussed herein. See tables.

162. See Frederic Brussat \& Mary Ann Brussat, Book Review, SPIRItuality \& Prac., http://www.spiritualityandpractice.com/books/books.php?id=25396 (last visited Mar. 19, 2014) (reviewing KARIMA BENNOUNE, Your Fatwa Does Not Apply Here: Untold Stories from the Fight Against Muslim FundaMENTALISM (2013)).

163. See Bhala, International Trade Law: Interdisciplinary Theory and Practice, supra note 3, at 339; see Table 5 .

VOL. 47 , NO. 3 


\begin{tabular}{lllll}
\hline$\backslash$ joiprod01\productn $\backslash I \backslash I N L \backslash 47-3 \backslash I N L 302 . t x t$ & unknown & Seq: 21 & 15-MAY-14 & $12: 26$ \\
\hline
\end{tabular}

DIVERSITY WITHIN UNITY

is no monolithic answer, no "one size fits all" explanation. Different OIC-WTO countries are different.

Consider five possibilities. First, some countries are less orthodox in their interpretation of Islamic legal precepts than others. ${ }^{164}$ Bangladesh and Saudi Arabia are cases in point. ${ }^{165}$ Second, some countries have large non-Muslim populations. ${ }^{166}$ For them, consumption of alcohol and pork is not prohibited.167 Third, some countries are interested in collecting tariff revenue from alcohol or pork imports, in preference to spending funds on customs and border patrol agents to deter smuggling of these items. ${ }^{168}$ Fourth, some countries have domestic breweries or pig farms of their own. ${ }^{169}$ Batam beer is brewed in Indonesia, as is Efes in Turkey, which also has pig farms. Invoking GATT Article XX(a) in such cases clearly would be hypocritical. ${ }^{170}$ Fourth, consciousness about these prohibitions is stronger in recent years, especially after September 11, 2001, than in past decades. ${ }^{171}$ Religious matters are more public today, so not drinking and not eating pork is not just a personal question, but also a trade issue. ${ }^{172}$ These answers are not mutually exclusive.

But arguably the most likely answer is a sixth one, lack of legal capacity. Many trade negotiators for OIC-WTO Members might not have known of the existence of GATT Article $\mathrm{XX}(\mathrm{a})$. Or, if they did, then they might not have appreciated how they could deploy this provision to implement the Shari’a prohibitions.

\section{B. Patterns in Respect of Article XX(A) Invocation}

As to a second set of empirical findings, suppose invocation of GATT Article $\mathrm{XX}(\mathrm{a})$ is regarded as a dependent variable and the (1) geographic region of a country, (2) percentage of Muslim population (i.e., religious pluralism), (3) per capita income, and (4) adult literacy rate are regarded as independent variables. Then, the following noteworthy patterns are apparent:

(1) Frequency?

Of all thirty-four OIC-WTO Member countries with Muslim-majority populations, only four expressly invoked Article XX(a) - the Kingdom of Saudi Arabia, Sultanate of Oman, Hashemite Kingdom of Jordan, and Yemen. ${ }^{173}$ Of these four

164. See, e.g., Shireen T. Hunter, The Future of Islam and the West: Clash of Civilizations or Peaceful Coexistence 153 (1998); U.A.B. Razia \& Akter Banu, Islam in Bangladesh 176 (1992).

165. See Hunter, supra note 164; see RAZIA \& BANu, supra note 164; see Tables.

166. See Pew Forum on Religion \& Pub. Life, The Future of the Global Muslim Population (2011).

167. See, e.g., Brunei Darussalam: Alcobol Advisory, supra note 45.

168. See Tariff Information by Country, supra note 159.

169. See, e.g., Efes Pilsener, BeER ADvocATe, http://www.beeradvocate.com/beer/profile/569/1506 (last visited Mar. 19, 2014); Brewsky \& Co Branding, BEHANCE, http://www.behance.net/gallery/Brewsky-Co-Branding/9991993 (last visited Mar. 19, 2014).

170. See Efes Pilsener, supra note 169; Brewscy \& Co Branding, supra note 169.

171. See Christopher Smith, Anti-Islamic Sentiment and Media Framing During the 9/11 Decade, J. ReLIGION \& SoC'Y, 2013, at 1, available at http://moses.creighton.edu/jrs/2013/2013-3.pdf.

172. See generally Wan Melissa Wan-Hassan, Globalising Halal Standards: Issues and Challenges, HaLaL J., July-Aug. 2007, at 38-39, available at http://www.academia.edu/243214/Globalising_Halal_Standards_Issues_and_Challenges.

173. See Table 5 .

WINTER 2013 


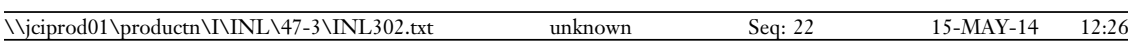

countries, only two of them—Saudi Arabia and Yemen—did so for the traditional Haram products, alcohol and pork. ${ }^{174}$

(2) Gulf Arab Countries?

This fact contrasts with an initial hypothesis, namely, OIC-WTO Member Gulf Arab countries easily would be the most conservative with respect to their trade policies toward these products, and thus the most aggressive in invoking Article $\mathrm{XX}(\mathrm{a}) .{ }^{175}$ This hypothesis perhaps reflects more of a stereotype, or hidden assumption, that strict views on Islamic Law in most Gulf countries would translate directly into protectionist trade policies against Haram (e.g., alcohol or pork) and Haramrelated products (e.g., distilling equipment or prepared ham sandwiches). ${ }^{176}$ Thus, it was anticipated Saudi Arabia would be the quintessential example, the lead that other Gulf countries would follow. 177 And indeed, the newest Gulf Arab country to join the WTO, Yemen, has invoked Article XX(a) for many more products than Saudi Arabia. ${ }^{178}$

But in truth, the Kingdom, joined in 2014 by Yemen, are unique examples. The Yemeni and Saudi invocations of Article $\mathrm{XX}(\mathrm{a})$ extend to the broadest range of commodities of any OIC-WTO Member. ${ }^{179}$ An illustration is the treatment of distillation equipment by the Kingdom. ${ }^{180}$ Such equipment has a dual use; as travelers to Saudi Arabia may have observed, some homes in the Kingdom have distillation equipment that may be used for the production of alcoholic beverages. ${ }^{181}$ But such equipment also may be used for reasons other than making beer, wine, or spirits, for example, perhaps in a chemistry classroom or laboratory. ${ }^{182}$ Likewise, Yemen invoked Article XX(a) not only for alcohol and pork products, but also poppy seeds, cameras that show the human body naked, and gambling tables, machines, or tools. ${ }^{183}$

(3) Non-Gulf Arab Countries and Turkey?

OIC-WTO Member non-Gulf Arab countries are unlike Gulf Arab countries with respect to invoking Article $\mathrm{XX}(\mathrm{a})$. Jordan is the only OIC-Member outside the Gulf to use Article $\mathrm{XX}(\mathrm{a})$, but it does not do so for Haram products. ${ }^{184}$

174. See Table 5 .

175. See generally Simon Henderson, The New Pillar: Conservative Arab Gulf States and U.S. Strategy (2003).

176. See Praveen Menon, Alcoholic Drinks Market Booming in Muslim Gulf, Reuters (Mar. 10, 2011, 7:32 AM), http://www.reuters.com/article/2011/03/10/uk-gulf-muslim-alcohol-idUSLNE72904E20110310.

177. See GATT (the Arab Countries and-), MEDEA INST., http://www.medea.be/en/themes/economy-andtrade/gatt-the-arab-countries-and/ (last visited Mar. 19, 2014).

178. See Table 5.

179. See Table 5.

180. See, e.g., Dep't Com., Gov't INDIA, SAUdi ARABIA, available at http://commerce.nic.in/trade/GCC \%20NTMS\%20final/Saudi\%20Arabia.doc (last visited Mar. 19, 2014); DHL, IMPORT GUIDE FOR THE KINGDOM OF SAUDI ARABIA, available at http://www.dhl-usa.com/content/dam/downloads/g0/express/shipping/customs/import_guide_sa_en.pdf (last visited Mar. 19, 2014).

181. See Dep'T Com., Gov't India, supra note 180; Alcohol in Saudi Arabia, DARA Thai., http://alcoholrehab.com/alcohol-rehab/alcohol-in-saudi-arabia (last visited Mar. 19, 2014).

182. See, e.g., Sulzer to Revamp Vacuum Distillation Unit for Saudi Aramco, Sulzer (Oct. 31, 2012), http:// www.sulzer.com/en/Newsroom/Group-News/2012/121031-Sulzer-to-Revamp-Vacuum-Distillation-Unit-

for-Saudi-Aramco.

183. See Table 5.

184. See Fordan Accession Report, supra note 47; see Table 5.

VOL. 47 , NO. 3 


\begin{tabular}{lllll}
\hline$\backslash$ joiprod01\productn $\backslash I \backslash I N L \backslash 47-3 \backslash I N L 302 . t x t$ & unknown & Seq: 23 & $15-M A Y-14$ & $12: 26$ \\
\hline
\end{tabular}

DIVERSITY WITHIN UNITY

Among non-Gulf Middle Eastern countries, those in the Levant are notably liberal in their trade policies toward these products. ${ }^{185}$ In particular, both Lebanon and Syria-though not yet WTO Members-not only permit importation of alcohol and pork products, but also produce and export those products. ${ }^{186}$ Indeed, they have reasonably diversified the alcoholic beverages industry, going beyond just beer and wine. ${ }^{187}$ Turkey, too, fits the pattern of producing and exporting such products. ${ }^{188}$

(4) Iran?

The Islamic Republic of Iran is a fascinating sui generis case. It is not yet a WTO Member, and images and stereotypes emanating from the 1978-1979 Islamic Revolution suggest alcohol and pork products are strictly Haram under a fanatically puritanical regime. ${ }^{189}$ In fact, the truth is more nuanced. Data from Iran reported by the United Nations and mirror statistics (i.e., data not obtained directly from Iran, but rather from partner countries with which Iran trades) suggest Iran produces and exports alcoholic beverages and pork. ${ }^{190}$ For example, Iran exported beer, wine, fermented beverages, and spirits—nearly everything except vermouthin 2012.191 As another example, while for 2010 and 2011 Iran did not appear to export pork, in 2012 it did. ${ }^{192}$

One interesting cause for this surprising finding may be American trade sanctions on Iran. ${ }^{193}$ These trade sanctions have become ever tougher, especially since the 1996 Iran and Libya Sanctions Act and amendments to it in 2010 and 2012, targeting

185. See, e.g., Lebanon, Middle E. Ass'N, http://the-mea.co.uk/countries/lebanon (last visited Mar. 19, 2014); EuropeAid, Eur. Comm'n, Trade Enhancement Programme (TEP) in Syria, available at http:/ /ec.europa.eu/europeaid/documents/case-studies/syria_trade_tep_en.pdf (last visited Mar. 19, 2014); see Table 5.

186. See List of Products Exported by Lebanon, INT'L TRADE CENTRE, http://www.intracen.org/country/lebanon (last visited Mar. 19, 2014) (follow "Trade in Goods Statistics" link, then click the "Product" drop down menu to view each of the following: "02-Meat and edible meat offal," "15-Animal, vegetable fats and oils, cleavage products, etc.," "16-Meat, fish and seafood food preparations," and "22-Beverages, spirits and vinegar."); see also List of Products Exported by Syrian Arab Republic, INT'L Trade Centre, http://www.intracen. org/country/syrian-arab-republic (last visited Mar. 19, 2014) (follow "Trade in Goods Statistics" link, then click the "Product" drop down menu to view each of the following: "02-Meat and edible meat offal," "15Animal, vegetable fats and oils, cleavage products, etc.," "16-Meat, fish and seafood food preparations" and "22-Beverages, spirits and vinegar.").

187. See List of Products Exported by Lebanon, supra note 186.

188. See List of Products Exported by Turkey, INT'L TRADE CENTRE, http://www.intracen.org/country/turkey (last visited Mar. 19, 2014) (follow "Trade in goods statistics" link, then click the "Product" drop-down menu to view both: "22-Beverages, spirits and vinegar" and "02-Meat and edible meat offal.").

189. See generally Danial Arjomandy, Iranian Membership in the World Trade Organization: An UNCLEAR Future (2013).

190. See List of Products Exported by Iran, INT'L TRADE CENTRE, http://www.intracen.org/country/iran/ (last visited Mar. 19, 2014) (follow "Trade in Goods Statistics" link, then click the "Product" drop down menu to view each of the following: "02-Meat and edible meat offal," "16-Meat, fish and seafood food preparations," and "22-Beverages, spirits and vinegar."). The Centre relied on mirror statistics to obtain data for 2012.

191. See List of Products Exported by Iran, supra note 190.

192. See id.

193. Iranian Transactions Regulations, 31 C.F.R. pt. 560 (2012).

WINTER 2013 


\begin{tabular}{lllll}
\hline \jciprod01\productn $\backslash I \backslash I N L \backslash 47-3 \backslash I N L 302 . t x t$ & unknown & Seq: 24 & 15-MAY-14 & $12: 26$ \\
\hline
\end{tabular}

a larger number of sectors of the Iranian economy. ${ }^{194}$ Starting with the petroleum industry, the United States extended trade sanctions to refined gasoline, finance, instruments of human rights abuses and press censorship, and precious metals. ${ }^{195}$ Possibly, Iran may be seeking to make up for export revenues denied to it by the sanctions by making and shipping alcohol and pork.

But the WTO accession terms of Iran, whenever they are finally agreed, will tell how scrupulously the Islamic Republic adheres in its trade policy, by invoking Article $\mathrm{XX}(\mathrm{a})$, to the Shari'a prohibitions.

(5) Indian Sub-Continent?

Conversely, OIC-WTO Member countries on the Indian Sub-Continent and Far East tend to be more liberal in social and cultural morays than those in the Gulf. 196 Their populations are, after all, relatively more diverse. ${ }^{197}$ Yet their tariff rates on alcohol and pork tend to be high, which may reflect more their protectionist trade policies than their desire to adhere to strict Islamic legal precepts. ${ }^{198}$

(6) Africa?

In OIC-WTO Member countries in North and Sub-Saharan Africa, there is an alignment between their relatively cosmopolitan social and cultural attitudes toward alcohol and pork, on the one hand, and their trade policies, on the other hand. ${ }^{199}$ Tariffs on these products tend to be lower than observed on the Indian SubContinent. ${ }^{200}$

(7) Religious Pluralism?

The above patterns suggest that more religiously pluralistic (but still Muslim-majority) OIC-WTO Member countries not only abjure use of Article XX(a), but also regard Haram products not so much as forbidden, but as any other kind of merchandise. Their importation is not to be banned, but to be regulated according to bound tariffs that reflect domestic political and economic concerns. Those concerns include protecting domestic producers of, and garnering tax revenues from, alcohol and pork. ${ }^{201}$ Simply put, Muslims in such countries interact daily with nonMuslims, and have for well over 1,000 years. ${ }^{202}$ Production, importation, and consumption of alcohol and pork are unsurprising behaviors to them.

194. Iran and Libya Sanctions Act of 1996, Pub L. No. 104-172, 110 Stat. 1541 (1996) (codified as amended at 50 U.S.C. $\$ 1701$ (2012)); see Raj Bhala, Fighting Iran with Trade Sanctions, 31 ARIZ. J. INT’L \& Comp. L. (forthcoming 2014).

195. See Kenneth Katzman, Cong. Research Serv., Iran Sanctions, RS20871, at 9, 11, 18, 26, 3031,35 (2014).

196. See, e.g., Junning Liu, Classical Liberalism Catches on in China, 11 J. Democracy 48, 48 (2000); India: Foreign Trade Policy, WorLD BANK, http://go.worldbank.org/RJEB2JGTC0 (last visited Mar. 19, 2014).

197. See Fed. Research Div., Library of Congress, Country Profile: India 7 (Dec. 2004), available at http://lcweb2.loc.gov/frd/cs/profiles/India.pdf.

198. See Tables 1-4.

199. See Jessica Hatcher, Africa's Drinking Problem: Alcoholism on the Rise as Beverage Multinationals Circle, TIME (Aug. 9, 2013), http://world.time.com/2013/08/09/africas-drinking-problem-alcoholism-on-the-riseas-beverage-multinationals-circle/.

200. See Tables 1-4.

201. See Trade Protection, Econ. Online, http://www.economicsonline.co.uk/Global_economics/Trade_ protectionism.html (last visited Mar. 19, 2014).

202. See, e.g., Hinduism-3: Interaction with Muslims, The S. Asian Idea Weblog, http://thesouthasianidea. wordpress.com/2008/10/24/hinduism-???-3-interaction-with-muslims (last visited Mar. 19, 2014).

VOL. 47 , NO. 3 


\begin{tabular}{|c|c|c|c|}
\hline 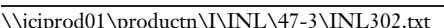 & unknown & Seg: 25 & 15-MAY-14 \\
\hline
\end{tabular}

DIVERSITY WITHIN UNITY

(8) Poverty and Education?

It is tempting to believe OIC-WTO Member countries with a low per capita income, and/or a low literacy rate, invoke Article XX(a). ${ }^{203}$ Posed as a hypothesis, the idea is that poor, uneducated Islamic populations are more likely to follow strict interpretations of Islamic law than Muslim communities that are richer, literate, and interactive with non-Muslim groups. ${ }^{204}$ That certainly is reasonable, and borne out in other contexts, but it is not apparent from the trade policies of these countries toward Haram products. ${ }^{205}$

Specifically, there is no clear negative correlation between income or education, on the one hand, and invocation of Article XX(a), on the other hand. ${ }^{206}$ Consider Saudi Arabia, Oman, Yemen, and Jordan, which invoked Article XX(a).207 Their populations, with the exception of Yemen, are relatively richer and better educated than their compatriots in other OIC-WTO Member countries; Saudi Arabia and Oman have relatively high per capita income (U.S. \$25,700 and \$28,500, respectively), and all three countries have relatively high literacy rates (81.4-92.6 percent). ${ }^{208}$

(9) Sunni-Shīìte Split?

The Sunni-Shi'ite split seems to have no impact on invocation of Article XX(a).209 That is, setting aside the special case of Iran, the balance between these two branches of Islam, or indeed an imbalance, within an OIC-WTO Member appears to have no bearing on how the Member treats imports of Haram products. ${ }^{210}$

Accordingly, an initial hypothesis that countries with larger Shi' itte populations will be more likely to ban forbidden products, or put higher tariff barriers on them, is incorrect. ${ }^{211}$ Here again, such a starting point may be grounded on an unfair stereotype, to the effect that one branch of Islam tends to be more extremism than another branch. ${ }^{212}$ The fact that some extremist groups claim (erroneously) to be authentically Sunni (e.g., Al Qaeda and Taliban), while others claim to be Shī'ite (e.g., Hezbollah) puts paid this stereotype. ${ }^{213}$ In any event, such groups have little effect on, if even knowledge of, trade policy. ${ }^{214}$

203. See World Factbook: Literacy, Cent. InTELLIGENCE AgENCY, https://www.cia.gov/library/publications/ the-world-factbook/fields/2103.html (last visited Mar. 19, 2014); GDP Per Capita (Current US\$), WoRLD BANK, http://data.worldbank.org/indicator/NY.GDP.PCAP.CD (last visited Mar. 19, 2014); see Table 1.

204. Cf. Raj Bhala, Poverty, Islamist Extremism, and the Debacle of Doba Round Counterterrorism: Part One of a Trilogy-Agricultural Tariffs and Subsidies, 9 U. ST. Thомаs L.J. 5, 22 (2011) [hereinafter Bhala, Part One].

205. Bhala, Part One, supra note 204, at 22; see generally Raj Bhala, Poverty, Islamist Extremism, and the Debacle of Doba Round Counter-Terrorism: Part Two of a Trilogy-Non-Agricultural Market Access and Services Trade, 44 Case W. Res. J. Int'L L. 325 (2011); Raj Bhala, Poverty, Islamist Extremism, and the Debacle of Doba Round Counter-Terrorism: Part Three of a Trilogy-Trade Remedies and Facilitation, 40 DENV. J. INT'L L. \& Pol'y 238 (2012).

206. See Table 5.

207. See Table 1, Table 5 .

208. World Factbook: Literacy, supra note 203; GDP Per Capita (Current US\$), supra note 203.

209. See Tables.

210. See Tables.

211. See Raj Bhala, Understanding Islamic Law (Sharî'a) 1310-37 (2011) (explaining why Islamist extremist views advocated by terrorist organizations are not authentically Islamic).

212. $I d$. at $\mathrm{xxxv}, 18,21$.

213. Id. chs. $48-50$.

214. See Tables.

WINTER 2013 


\begin{tabular}{lllll}
\hline \jciprod01\productn $\backslash I \backslash I N L \backslash 47-3 \backslash I N L 302 . t x t$ & unknown & Seq: 26 & 15-MAY-14 & $12: 26$ \\
\hline
\end{tabular}

Each of these patterns could be re-tested with sophisticated (but problematic) statistical and econometric techniques, such as correlation coefficients and multivariable regression analysis. $^{215}$

For now, however, note the importance of considering WTO accession dates. ${ }^{216}$ Countries that joined the GATT as contracting parties, sometimes under the wing of their former colonial master (e.g., Indonesia under the Dutch), joined in a pre-WTO era when religion was less of a public, trade-related issue. ${ }^{217}$ Put differently, the accession date itself may be an independent variable, with later-in-time dates corresponding to a period of greater "Islamic consciousness" in the public sphere. ${ }^{218}$

\section{Specific Findings}

In addition to the patterns noted above, several findings specific to one or a subset of Islamic countries are evident from Tables 1 through 4. They are as follows:

(1) Former Communist Countries

Three former Communist countries (Albania, Kyrgyz Republic, and Tajikistan), all of which have sizeable Muslim majorities and are at different stages of economic growth and development, did not invoke Article XX(a). ${ }^{219}$ The reason may be exogenous, namely, historical and cultural.220 The legacy of Soviet influence included (inter alia) official Atheism and an environment in which drinking alcoholic beverages was acceptable. 221

(2) Non-Invocation in GATT Era Accessions

A large number of Muslim-majority OIC-WTO Members did not invoke GATT Article XX(a) during their accession negotiations. ${ }^{222}$ For some of them, especially ones that joined GATT as contracting parties before the birth of the WTO on January 1, 1995, they appear to have done so under Article XXXIII, under the auspices of their former colonial masters. ${ }^{223}$ These countries essentially entered on the terms of those masters that, being European, would not have included public morality concerns under the Sharì'a.224

215. See generally M. Hashem Pesaran, Econometrics, available at http://www.stanford.edu/ doubleh/ eco270/E000005.doc (last visited Mar. 19, 2014).

216. See generally Members and Observers, World Trade OrG., http://wto.org/english/thewto_e/whatis_e/ tif_e/org6_e.htm (last updated Mar. 19, 2013).

217. See generally World Trade Org., WTO Analytical Index: Guide to WTO LaW and Practice 97-388 (3d ed. 2012).

218. See Japanese Inst. of Middle E. Economies, A Study on the Interdependence of the IsLamic World and the Confrontation and Competition Within (Mar. 1998), available at http:// www.nira.or.jp/past/publ/houko/i970106.html.

219. See World Factbook: Religions, Cent. InTELligenCE AgenCy, https://www.cia.gov/library/publications/ the-world-factbook/fields/2122.html (last visited Mar. 19, 2014); see Table 1; Tim Heleniak, Diasporas and Development in Post-Communist Eurasia, Migration Pol’y Inst. (June 28, 2013), http://www.migrationpolicy.org/article/diasporas-and-development-post-communist-eurasia.

220. World Factbook: Religions, supra note 219; see Table 1; Heleniak, supra note 219.

221. See Sergei Gradirovski \& Neli Esipova, Russian Muslims: Religious Leaven in a Secular Society, 30 Harv. INT'L Rev. Spring 2008, at 58.

222. See Tables.

223. See GATT art. XXXIII. See generally WORLD TRADE ORG., supra note 217 (noting that former colonies could accede to the GATT through the procedure provided in GATT Article XXVI:5).

224. See World Trade Org., supra note 217.

VOL. 47 , NO. 3 


\begin{tabular}{lllll}
\hline$\backslash$ jciprod01\productn $\backslash I \backslash I N L \backslash 47-3 \backslash I N L 302 . t x t$ & unknown & Seq: 27 & 15-MAY-14 & 12:26 \\
\hline
\end{tabular}

DIVERSITY WITHIN UNITY

(3) Importation Allowed but Unbound Tariffs

From the perspective of a producer-exporter or importer of merchandise, an unbound tariff rate poses the greatest uncertainty. 225 That is because a country of importation is not committed to a ceiling rate under GATT Article II:1(b), hence it may apply any duty, no matter how high. ${ }^{226}$ Importation still may occur, but if the applied rate is substantial enough, the merchandise is effectively barred from the market.227 In such cases, there is a great incentive to smuggle the high-tariffed articles. $^{228}$

Some OIC-WTO Member countries deal with Haram products not by an express invocation of GATT Article XX(a) banning their importation as immoral, but rather via refusing to bind their tariffs on them. ${ }^{229}$ Pakistan and Brunei are examples with respect to alcohol. ${ }^{230}$ Their unbound, 2013 applied rates are 90 percent and 100 percent, respectively.231 Similarly, for pork products, Pakistan has an unbound, applied rate of 90 percent and Brunei has an unbound, applied rate of 100 percent. ${ }^{232}$

(4) Importation Allowed but High Tariffs

For a large number of Muslim-majority OIC-WTO Members that did not invoke GATT Article XX(a) during their accession negotiations, their HS Schedule of Tariff Concessions reveals they allow importation of Haram goods, namely, alcohol and pork products, but not pornography. ${ }^{233}$ Even a short stay as a tourist in such countries can confirm the point, as in countries like Indonesia, Malaysia, and Tur-

225. See Yoginder K. Alagh, State of the Indian Farmer: A Millennium Study, Volume 1: An Overview 213 (2004).

226. GATT art. II:1(b).

227. See Duncan Green \& Matthew Griffith, Catholic Agency for Overseas Dev., Dumping on the Poor: The Common Agricultural Policy, the WTO and International Development (Sept. 2002), available at http://www.iatp.org/files/Dumping_on_the_Poor_The_Common_Agricultural_Po. htm.

228. See Paul M. Gutierrez, Rice Policy 'Punishes' Consumers, J. OnLINE (Feb. 24, 2014), http://www.journal. com.ph/index.php/news/headlines/67712-rice-policy-punishes-consumers.

229. See, e.g., WTO, Data on MFN Applied Tariff: Brunei Darussalam (Mar. 5, 2014), available at http://stat.wto.org/idbdata/idb_brn_last_e.zip; World Trade Org., BOUnd CONCESSIONS AT THE HS 6Digit Subheading Level: Pakistan (2002), available at http://stat.wto.org/idbdata/cts_pak_e.zip; WTO, Data on MFN Applied TARIFF: Pakistan (Mar. 5, 2014), available at http://stat.wto.org/idbdata/idb_pak_ last_e.

230. See WTO, Data on MFN Applied Tariff: Pakistan, supra note 229; WTO, Data on MFN Applied Tariff: Brunei Darussalam, supra note 229; Brunei Darussalam Tariff Profile, World Trade ORG., http://stat.wto.org/tariffprofile/wsdbtariffpfview.aspx?language=e\&country=bn (last visited Mar. 19, 2014).

231. Data for tariffs applied by Pakistan on pork and alcohol products are based on the MFN Applied Tariff at the HS 6-Digit Sub-Heading Level, HS 2012, last updated March 5, 2014, which is based on notifications to the Integrated Database (IDB). WTO, Data on MFN Applied Tariff: Pakistan, supra note 229. This information is posted on the WTO website at http://www.wto.org/english/tratop_e/schedules_e/ goods_schedules_table_e.htm\#top.

232. WTO, Bound Concessions at the HS 6-Digit Subheading Level: Brunei Darussalam (2002), available at http://stat.wto.org/idbdata/cts_brn_e.zip; WTO, BOund CONCESSIONS AT THE HS 6Digit Subheading Level: Pakistan, supra note 229; WTO, Data on MFN Applied Tariff: Brunei DARUSSALAM, supra note 229.

233. See e.g., WTO, Bound Concessions at the HS 6-Digit Subheading Level: Turkey (2002), available at http://stat.wto.org/idbdata/cts_tur_e.zip.

WINTER 2013 


\begin{tabular}{lllll}
\hline \jciprod01\productn $\backslash I \backslash I N L \backslash 47-3 \backslash I N L 302 . t x t$ & unknown & Seq: 28 & 15-MAY-14 & $12: 26$ \\
\hline
\end{tabular}

key, beer and wine are available (and, in Turkey, produced). ${ }^{234}$ The Tariff Schedules of these countries reveal importation of Haram goods may occur at bound MFN duty rates that are extraordinarily high (e.g., 200 percent). ${ }^{235}$

But to characterize a tariff as "high" begs a question, "high" relative to what? That is, tariffs are meaningful in a relative sense, thus it is useful to begin with some benchmarks against which OIC-WTO Member duty rates can be gauged.

The simple mean bound tariff rate for all products of all countries (WTO and nonWTO Members) is 32.72 percent. ${ }^{236}$ For low-income economies, the simple mean bound tariff rate is 50.45 percent. ${ }^{237}$ These countries are defined as ones with a per capita GNP of $\$ 1,035$ or less. ${ }^{238}$ Most least-developed countries (LDCs) are considered low-income or low-middle income.239 Among OIC-WTO Members, all but four LDCs are also classified as low-income economies. ${ }^{240}$ Yemen, Djibouti, Mauritania, and Senegal are lower-middle-income economy countries. ${ }^{241}$

In contrast, for high-income countries, the average tariff rate is 22.1 percent. $^{242}$ These countries are defined as ones with a per capita GNP of $\$ 12,616$ or greater. ${ }^{243}$ Among OIC-WTO Members, most of the Gulf Arab countries and Brunei would be included as "high-income." 244

Using these figures as benchmarks, it can be said with confidence that virtually all OIC-WTO Members have "high" tariffs on Haram goods. ${ }^{245}$ Only a handful of these Members have tariffs below or in the range of 22.1, 32.7, or 50.5 percent, namely Bahrain (pork products), Brunei (pork products), Jordan (pork products), Morocco, Kyrgyz Republic, Djibouti (pork products), Côte d'Ivoire, Guinea, Guinea-Bissau, Mali, Senegal, Sierra Leone (pork products), Indonesia (pork products), and Albania. ${ }^{246}$

234. See Alcohol Prices in Malaysia, MyTravelCost.com, http://www.mytravelcost.com/Malaysia/prices-alcohol/ (last visited Mar. 19, 2014); Alcohol Prices in Indonesia, MrTravelCost.com, http://www.mytravelcost.com/Indonesia/prices-alcohol/ (last visited Mar. 19, 2014); Alcohol Prices in Turkey, MrTravelCost.COM, http://www.mytravelcost.com/Turkey/prices-alcohol/ (last visited Mar. 19, 2014).

235. E.g., WTO, Schedule XXI: IndONESIA, available at http://www.wto.org/english/tratop_e/schedules_e/idn.zip (last visited Mar. 19, 2014).

236. World Development Indicators: Tariff Barriers, WORLD BANK, http://wdi.worldbank.org/table/6.6 (last visited Mar. 19, 2014).

237. Id.

238. How We Classify Countries, WORLD BANK, http://data.worldbank.org/about/country-classifications (last visited Mar. 19, 2014).

239. A list of Least Developed Countries is posted on the United Nations Development Policy and Analysis Division website, List of Least Developed Countries, UnITED NATIONS, http://www.un.org/en/development/ desa/policy/cdp/ldc/ldc_list.pdf (last visited Mar. 19, 2014). The World Bank has a list of low to high income economies, Country and Lending Groups, WORLD BANK, http://data.worldbank.org/about/country-classifications/country-and-lending-groups\#Low_income (last visited Mar. 19, 2014) (scroll down to "Low-income economies" heading).

240. See Country and Lending Groups, supra note 239.

241. See id.

242. World Development Indicators: Tariff Barriers, supra note 236.

243. How We Classify Countries, supra note 238.

244. See Country and Lending Groups, supra note 239.

245. See also Standing Committee for Economic and Commercial Cooperation of the Organization of Islamic Cooperation [COMCEC], COMEC Trade Outlook 2013, 21 (2013), available at http://www.comcec.org/ UserFiles/File/WorkingGroups/Trade/COMCEC_Trade_Outlook_2013.pdf.

246. See Tables.

VOL. 47 , NO. 3 


\begin{tabular}{|c|c|c|c|}
\hline 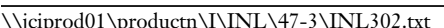 & unknown & Seg: 29 & 15-MAY-14 \\
\hline
\end{tabular}

DIVERSITY WITHIN UNITY

Of course, a more targeted set of benchmarks would be tariff rates for specific Haram goods, namely, the product categories covering alcohol and pork. Finding average bound tariff rates on such merchandise is surprisingly difficult. ${ }^{247}$ One reason may be that many countries impose a specific duty on alcohol, pork, or both. ${ }^{248}$ So, for them it is necessary to computing an AVE figure.

There are several ways to calculate AVEs. Put most simply, AVE is the value of the tariff divided by the unit value. ${ }^{249}$ The unit value is "the value of a particular trade flow during a specified period divided by its volume." 250 But there are several ways to calculate the unit value, and an AVE assessment can vary depending on how the unit value is calculated.251 AVEs can also differ if the price of the product varies..$^{252}$ In lieu of, or in addition to, product-specific duty rate averages across countries, a possible benchmark is an average for a sector. ${ }^{253}$ Both alcoholic beverages and pork fall within the agricultural sector. ${ }^{254}$ The global average agricultural bound tariff was approximately 62 percent in 2001.255 That average was derived in part from AVEs and does not take into account alcoholic beverages. ${ }^{256}$

With these points in mind, Egypt is a case in point. It has the highest ad valorem tariff on alcohol of any OIC-Muslim country, 3,000 percent. ${ }^{257}$ Maldives is another example. ${ }^{258}$ It has one of the highest bound rates for pork, 300 percent, plus an ODC of one percent. 259

Accordingly, most Muslim countries allow importation of Haram goods, namely, alcohol and pork products, but have scheduled fairly high bound MFN rates on them. ${ }^{260}$ But the adverb "fairly" is important; "fairly" in relation to what other duty rates?

If the comparison is to bound duty rates among developed countries, then the numbers indeed are high. Rich countries have far lower bound rates on most items than poor countries. ${ }^{261}$ But if the comparison is to bound levels set by the same country,

247. See Subcommittee on Unfair Trade Policies and Measures, Report on the WTO Inconsistency of Trade Policies by Major Trading Partners, 44 n.5 (2000).

248. See Tables.

249. See WTO, United Nations Conference on Trade and Development \& International Trade Centre, World Tariff Profiles 2013, at 194 (2013), available at http://www.wto.org/english/res_e/booksp_e/tariff_ profiles13_e.pdf.

250. Id. at 197 .

251. Id. at 4 .

252. Id.

253. See generally UKPIs: Adjusted Sector Benchmarks - Technical Notes and Detailed Information, HiGHER EDUc.STAT. AGENCY, http://www.hesa.ac.uk/index.php?option=com_content\&task=view\&id=2059\&Itemid $=141$ (last visited Mar. 19, 2014).

254. See Agreement on Agriculture, annex 1.

255. Econ. Research Serv., U.S. Dep't of Agric., Profiles of Tariffs in Global Agricultural MARKETs iv (2001), available at http://www.ers.usda.gov/ersDownloadHandler.ashx?file=/media/919871/ aer796.pdf.

256. See id. at 39.

257. See Table 3.

258. See Table 2.

259. See Table 2.

260. See Table 1.

261. See Tables.

WINTER 2013 


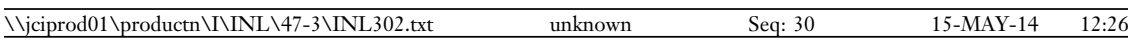

then "fairly" might mean "pretty much average." Bangladesh is a case in point. ${ }^{262}$ Many Bangladeshi tariff lines for agricultural products are 200 percent, so a 200 percent duty on alcohol is in line with levies on other agricultural goods. ${ }^{263}$

(5) Ad Valorem versus Specific Duties and Maximization of Tariff Revenues

Almost all Muslim countries that impose a bound MFN duty on Haram goods use an ad valorem rate. ${ }^{264}$ Kyrgyzstan and Malaysia are notable exceptions. ${ }^{265}$ Kyrgyzstan uses specific duties and hybrid (compound) duties that are a mix of ad valorem and specific duties. ${ }^{266}$ Malaysia uses specific duties for all alcoholic beverages. ${ }^{267}$ Use of a specific duty is economically imprudent. The duty does not adjust for inflation, as it is tied only to the volume of imported merchandise.268 So, for example, Malaysia levies a specific duty for beer imports of 150 Ringgit Malaysia $(R M)$ per decaliter (dal).269 That means Malaysia collects the same revenue from a shipment of Bud Lite or Miller Lite as it does from a shipment of Sam Adams or Brooklyn Lager, assuming the shipments are of the same volume. Manifestly, the prices of Bud and Miller Lite are lower than those of the craft beers (presumably reflecting quality). ${ }^{270}$ Bluntly put, then, if Malaysia—as a Muslim country-is not going to ban importation of alcoholic beverages, then it might as well maximize the tariff revenue it collects from such beverages by using ad valorem instead of specific duty rates.

(6) Lowering of Protections against Haram Goods

As indicated earlier, for OIC-WTO Members for which data in their Uruguay Round or Accession Protocol Schedule were insufficient, it was necessary to consult their most recently posted Schedule (if any), typically the 2002 Schedule.

Checking the most recent Schedule gave the opportunity to see if a Member actually might have lowered its bound rate on a Haram good. The answer was "yes" in the case of Jordan. ${ }^{271}$ Its Schedule as of 2002 showed duty rates on pork and pork products ranging from an average of 10 percent to 30 percent. $^{272}$ But its Uruguay Round Schedule showed rates on these products around 200 percent. ${ }^{273}$ Jordan, then, had lowered its bound ad valorem MFN tariffs on pork and pork products in the years following the conclusion of that Round. ${ }^{274}$

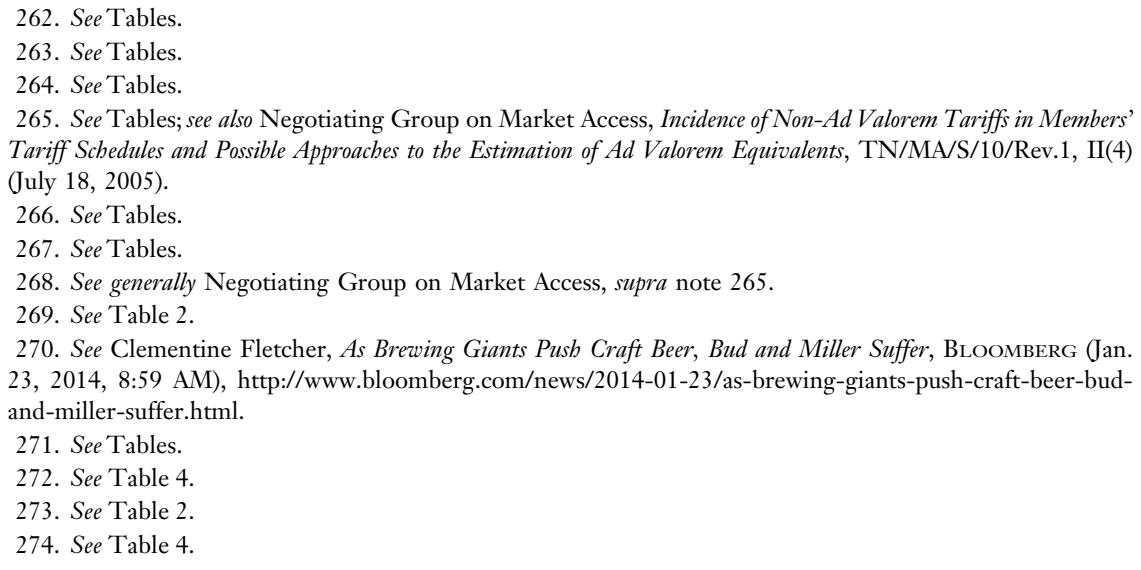

VOL. 47 , NO. 3 


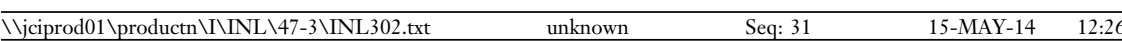

DIVERSITY WITHIN UNITY

The answer also was "yes" in the case of Turkey.275 It lowered from 120 and 100 percent on geneva and gin, respectively, its bound rate to a maximum of 102 percent. ${ }^{276}$ Turkey also refined its product classification of various products, particularly pork. ${ }^{277}$

(7) Use of $O D C s$

Several OIC-WTO Members, predominantly in Africa, impose not only OCDs, but also ODCs, on certain Haram goods. ${ }^{278}$ These nineteen countries are Kuwait, Qatar, Morocco, Djibouti, Burkina-Faso, Côte d'Ivoire, The Gambia, Guinea, Guinea-Bissau, Mali, Mauritania, Niger, Nigeria, Senegal, Sierra Leone, Bangladesh, Maldives, Indonesia, and Malaysia.279 The GATT Article II:1(b) tariff binding principle, in the first and second sentences, respectively, applies to both types of levies. ${ }^{280}$

Unfortunately, the WTO Accession Protocols and Schedules of these countries do not chronicle in detail the nature of the ODCs. ${ }^{281}$ In other words, what they are and why they are imposed, is unclear from those documents. But three points are apparent from them.

First, many ODCs take the form of an ad valorem charge and are listed as such, namely, "ODC AV," in the Schedules. ${ }^{282}$ Presumably, that means the ODC is a percentage of the value of the shipment of a Haram good. ${ }^{283}$ Second, some of the ODCs are imposed on a non-AV basis. ${ }^{284}$ Some of them appear to be minimum fees, such as per bottle, per volume, or per weight. ${ }^{285}$

Third, the ODCs are not insignificant. ${ }^{286}$ They tend to add a material cost to the importer of Haram goods and sometimes can be prohibitive. ${ }^{287}$ For example, for alcoholic beverages, Morocco imposes a 34 percent tariff, plus a 15 percent ODC AV. ${ }^{288}$ In Djibouti, for alcoholic beverages, the bound tariffs start at 150 percent, with considerable upward variation depending on the type of alcohol. ${ }^{289}$ On pork products, the bound tariffs are 40 percent. ${ }^{290}$ But for both alcoholic beverages and pork, the average ODC AV is 100 percent. ${ }^{291}$ Thus, relative to Morocco, Djibouti

275. See Tables.

276. See Table 3, Table 5.

277. See generally Eurostat, European Commission, List of Industrial Product of Turkey 2012, PRODTR 2012 (2012), available at http://tuikapp.tuik.gov.tr/DIESS/FileDownload/Yayinlar/Siniflamalar/PRODTR_2012. pdf.

278. See Tables.

279. See Tables.

280. GATT art. II:1(b).

281. See Tables.

282. See Table 5.

283. See Table 5.

284. See Table 5.

285. See Table 5.

286. See Table 5.

287. See Table 5; see also Peter John Williams, WTO, A Handbook on Accession to the WTO 72 (2008).

288. See Table 2.

289. See Table 2.

290. See Table 4.

291. See Tables 2-4.

WINTER 2013 


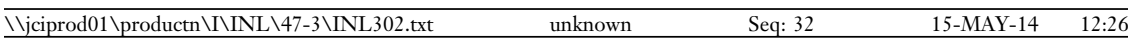

imposes a whopping ODC on top of a stratospheric OCD, the combined effect of which is prohibitive.

(8) Missing Data and Inferences Therefrom

For some OIC-WTO Members, no pertinent data on GATT Article XX(a) invocation for Haram goods is listed in their Protocol, Report, Annexes, or Schedules. ${ }^{292}$

That means nothing can be inferred from those WTO sources as to whether importation of such goods is or is not banned. But credible evidence from other sources indicates alcohol and/or pork is available for lawful consumption under restricted circumstances. These sources include HS Schedules, International Trade Centre, Lonely Planet travel guides, media reports, and the travel experiences of the authors. ${ }^{293}$ These countries include Kuwait, Tunisia, and Bangladesh. ${ }^{294}$

The typical pattern in these countries is alcohol and/or pork is available in limited venues, such as luxury hotels and restaurants. ${ }^{295}$ This pattern suggests two possibilities. The first, and more likely, possibility is importation of alcohol and/or pork is lawful, i.e., no Article $\mathrm{XX}(\mathrm{a})$ exception was taken. ${ }^{296}$ But importation is restricted in some way, typically a high tariff, a quota, or a tariff rate quota (TRQ), coupled with licensing of permissible importers. ${ }^{297}$

The second possibility is that importation is forbidden, so such products enter via smuggling, but their consumption is lawful. 298 The second possibility would be a protectionist one, in support of one or more domestic producers, conferring on them a monopoly.

Malaysia and pork presents a case in point. ${ }^{299}$ The Malaysian Schedule is confusing as to "[f]resh or chilled meat of swine (excluding carcasses and half-carcasses, and hams, shoulders and cuts thereof, with bone in)," which is HS Code 020319.300 The Schedule contains no information, other than a dot, in the relevant Columns $\left(5,6\right.$, and 7). ${ }^{301}$ Do the dots mean "same as above HS Code," i.e., the same tariff as the entry before HS Code 020319? No, because the Schedule contains columnar repetitions. ${ }^{302}$ Indeed, it does so immediately above and below HS Code 020319 (with a duty rate of 139 percent on the above and below Codes). ${ }^{303}$ Do the dots

\footnotetext{
292. See Table 5.

293. See generally Trade Statistics, INT'L TRADE CenTRE, http://www.intracen.org/itc/market-info-tools/ trade-statistics/ (last visited Mar. 19, 2014); Introducing Bangladesh, Lonely Planet, http:// www.lonelyplanet.com/bangladesh (last visited Mar. 19, 2014).

294. See, e.g., Pangtidor, Comment to What to Pack for Kuwait, Virtual Tourist, http://www.virtualtourist.com/travel/Middle_East/Kuwait/Packing_Lists-Kuwait-MISC-BR-1.html (last visited Mar. 19, 2014); Lesley, Comment to Best Time to Go to Tunisia?, World Travels, http://www.wordtravels.com/ forum/discussion/2845/best-time-to-go-to-tunisia/p2 (last visited Mar. 19, 2014); Mikey Leung \& BeLindA MegGitt, Bangladesh 243 (2d ed. 2012).

295. See, e.g., Lesley, Comment to Best Time to Go to Tunisia?, supra note 294.

296. Trade Protection, supra note 201.

297. See Table 5.

298. See Table 5.

299. See Table 5.

300. See Table 5.

301. See Table 5.

302. See Table 5.

303. See Table 5.
}

VOL. 47 , NO. 3 


\begin{tabular}{|c|c|c|c|}
\hline 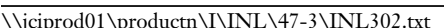 & unknown & Seg: 33 & 15-MAY-14 \\
\hline
\end{tabular}

mean "Unbound?" No, because Column 2 states "B," for "Bound." 304 Column 8 indicates the percentage of tariff lines under the HS Code 020319 that are duty free is zero, suggesting Malaysia does not give duty-free treatment for that coded merchandise. ${ }^{305}$ But no duty (whether ad valorem, specific, or hybrid) is listed in any other column. ${ }^{306}$

This example is important. Fresh and chilled pork is a common retail grocery item. Not knowing whether a tariff barrier exists, and if so what it is, obviously is troubling to prospective producers, distributors, and consumers.

\section{Patterns in Respect of Seven Import Measure Classifications}

If there is one obvious bottom line conclusion from Tables 2, 3, and 4, then it is summarized by the phrase "diversity within unity" across Muslim-majority OIC-WTO Members. That is because the following points are clear from the slotting of these countries in the seven import measure Classifications in these Tables:

(1) Very Low Tariff Policy (0-29 percent)

With respect to alcoholic beverages, a sizeable number of countries are in this category: eleven out of thirty-four for beer (32.3 percent), and eight out of thirty-four (23.5 percent) for wine and spirits, collecting some revenues on Haram goods but not deterring their importation or consumption. ${ }^{307}$

As for pork products, there is a clear concentration of countries in the Very Low and Low Tariff Classifications-44.1 and 23.5 percent, respectively. 308

(2) Low Tariff Policy (30-49 percent)

Few countries fall in this category for alcoholic beverages, two with respect to beer and four with respect to wine and spirits. ${ }^{309}$ In contrast, they do populate this category as regards pork products. ${ }^{310}$

(3) Medium Tariff Policy (50-99 percent)

A small number of countries-four for beer, seven for wines and spirits, and two for pork products-are in this category. ${ }^{311}$ Presumably, they seek to collect significant revenue on this merchandise, but not stamp out its consumption.

(4) High Tariff Policy (100-299 percent)

There is concentration of countries in this category, with fourteen out of thirty-four (41.1 percent) in it for beer and seventeen out of thirty-four (50 percent) in it for wines and spirits. ${ }^{312}$ That also is true for pork products, with fourteen out of thirtyfour (or 41.1 percent) of them pursuing the High Tariff Policy. ${ }^{313}$ Apparently, they are sending either or both of two signals, discourage consumption or collect revenue.

304. See Table 5.

305. See Table 5.

306. See Table 5.

307. See Tables 2, 3.

308. See Table 4.

309. See Tables 2, 3.

310. See Table 4.

311. See Tables 2-4.

312. See Tables 2, 3.

313. See Table 4.

WINTER 2013 
(5) Probibitive Tariff Policy (over 300 percent)

No country takes the purportedly Prohibitive Tariff approach to prevent importation of pork products, and almost no country does so for alcohol. ${ }^{314}$ Egypt is the sole occupier of this category for all alcoholic beverages, though Djibouti uses it for wine and spirits. ${ }^{315}$ Interestingly, Egypt modestly lowered its ultra-high tariff following the Uruguay Round. 316

(6) Import Ban Policy

Only Saudi Arabia and Yemen invoke GATT Article XX(a) to ban importation of alcohol or pork as necessary to protect public morality as that morality is defined under Islamic Law. 317 Whether that is or should be the metric for alignment of international trade law with Sharì $a$ is debatable, but plainly just two countries seem to think it is.

(7) Unbound Policy

Only Pakistan refuses to bind its MFN duty rates on all Haram products, and only Brunei does so on alcohol. ${ }^{318}$ Producer exporters thus lack certainty and predictability about what measures Pakistan or Brunei may impose on them.

In addition, as Tables 2, 3, and 4 illustrate, there is dispersion among the countries in three respects.

First, and least importantly, some countries impose different levels of protection against wines and spirits within a particular category. ${ }^{319}$ That also occurs with respect to pig fat versus other pork products. 320

Second, some countries treat beer differently from cider or perry, and some of them distinguish among types of wines and spirits. 321 They do so to the extent to warrant categorization in multiple Classifications, indicating dispersion across those Classifications. Here again, that occurs for pig fat. ${ }^{322}$

Third, for beer and for wines and spirits, every Classification is populated, and all but one is for pork products. ${ }^{323}$ That fact, in itself, adduces that OIC-WTO Members with Muslim majority populations are not all like-minded in whether and how they make consistent their import measures with Sharìa $a$ precepts about Haram goods. What is interesting to see, and perhaps worthy of more research, is polarization within this dispersion, namely, the existence of concentrations in Very Low or Low Tariff Classifications at one end, and in the High Tariff Classification at the other end. 324

314. See Tables 2-4.

315. See Table 2.

316. See Tables 2,5

317. See Saudi Arabia Accession Report, supra note 47; Table 5.

318. See Table 5.

319. See Table 3.

320. See Table 4.

321. See Table 3.

322. See Table 4.

323. See Tables 2-4.

324. See Tables 2-4.

VOL. 47 , NO. 3 


\begin{tabular}{lllll}
\hline \} \text { jciprod01\productn } \backslash I \backslash I N L \backslash 4 7 - 3 \backslash I N L 3 0 2 . t x t $&{\text { unknown }} &{\text { Seq: 35 }} &{\text { 15-MAY-14 }} &{\text { 12:26 }} \\
{\hline}$
\end{tabular}

DIVERSITY WITHIN UNITY

\section{E. Special Case of Pornography}

Obviously, pornography is one Haram product. ${ }^{325}$ That is true not only under the Shari' $a$, but also under United States trade law that pre-dates GATT, namely, the SmootHawley Tariff Act. ${ }^{326}$ To ascertain which OIC-WTO Members have put an outright import ban on pornography in their Schedule of Tariff Concessions, the logical move is to check those Schedules. But the HS does not list "pornography" as a specific product category with an attendant HS number. To rely on this methodology would yield an under-inclusive result of zero. But it would be wrong to infer from the lack of an HS line item for pornography that no Muslim country bans the product.

So, the next logical move is to check those Schedules for product categories that embody pornography, i.e., through which pornography is distributed: printed materials, audio-visual DVDs, and music CDs would be the prominent ones. ${ }^{327}$ But this methodology is over-inclusive. No Muslim country bans all printed materials, DVDs, and CDs. ${ }^{328}$ Rather, some impose low or mid-range tariffs (e.g., 10-15 percent), which are below the tariffs they impose on alcoholic beverages, on these goods. Others do not even list such items in their Schedules. ${ }^{329}$

It is likely that the safest course is to discount silence in Schedules and presume all Muslim countries, like many non-Muslim ones, ban importation of pornography. They do so under their own domestic legal instruments, for which GATT Article XX(a) doubtless would be a justification. ${ }^{330}$ But pornographic items, like other unlawful goods, tend to enter such countries through smuggling. ${ }^{331}$

\section{From How to Why?}

The above discussion addresses the question how Muslim countries treat Haram goods. The empirical data analyzed above reveal that Islamic countries tend to behave like nonIslamic ones, especially developing ones, as regards their trade rules on alcohol and pork products. ${ }^{332}$ They tend not to ban importation of these items, which would be the logical trade measure if they followed the Sharìa strictly. ${ }^{333}$ Instead, Muslim countries tend to impose high, revenue-generating tariffs and exhibit diversity in terms of the levels and features of those barriers. ${ }^{334}$

325. See, e.g., Prohibited Business Activities, Muslim Investor (Nov. 22, 1999, 7:48 AM), http://musliminvestor.com/mi/prohibited.phtml.

326. 19 U.S.C. $\$ 1305$ (a) (2011). This statute initially was enacted as part of the Tariff Act of 1930 and is sometimes called the "Smoot-Hawley Tariff Act." Tariff Act of 1930, Pub L. No. 71-361, 46 Stat. 590 (1930).

327. See, e.g., Kerby Anderson, Pornography-A Biblical Worldview Perspective, Probe Ministries, http:// www.probe.org/site/c.fdKEIMNsEoG/b.4218371/k.A2EE/Pornography.htm (last visited Mar. 19, 2014).

328. See Tables; Freemuse, All That Is Banned Is Desired 5 (2006), available at http://freemuse.org/ graphics/Publications/PDF/All_that_is_bannedFINAL31May06.pdf.

329. See Tables.

330. See GATT art. XX(a).

331. See, e.g., Mufti Syed Ziauddin Naqshbandi Qadri, Smuggling Goods into the Country, ZiaIslamic, http:// www.ziaislamic.com/english/Interfaces/fatawa_english/index.php?qid=1000\&frommostrecent=yes\#.UNgYhk q5FW4.facebook (last visited Mar. 19, 2014).

332. See Tables.

333. See Tables.

334. See Tables 2-4.

WINTER 2013 


\begin{tabular}{lllll}
\hline \jciprod01\productn $\backslash I \backslash I N L \backslash 47-3 \backslash I N L 302 . t x t$ & unknown & Seq: 36 & 15-MAY-14 & $12: 26$ \\
\hline
\end{tabular}

The natural next question is "Why?," that is, "Why do Muslim countries treat Haram goods the way they do?" A full exploration of this issue is beyond the present scope, but the following four explanations are readily apparent: legal capacity, tolerance, moral relativism, and secularism. They are not mutually exclusive and perhaps even complementary to some degree. Moreover, different explanations may attach better to different countries.

\section{A. Legal Capacity?}

First, some Islamic countries simply may lack the legal capacity to appreciate they have the choice to ban alcohol and pork products under GATT Article XX(a). ${ }^{335}$ When they were negotiating accession to GATT or the WTO, they may have failed to realize invocation of Article XX(a) was possible. Once they acceded, they may have not understood that they could modify their Schedule of Concessions, albeit with payment of appropriate compensation to affected exporting countries, under Article XXVIII bis.

This explanation may be especially pertinent to Islamic countries that entered GATT under the auspices of their former European colonial masters, which almost certainly had a relaxed attitude toward "forbidden" merchandise. The North and Sub-Saharan African countries are examples. ${ }^{336}$

\section{B. Tolerance?}

Second, Islamic law historically has been tolerant of religious minorities and their practices. ${ }^{337}$ During the Umayyad and Abbasid Caliphates, and Ottoman and Mughal Eras, Islamic leaders governed vast territories encompassing Jews, Christians, Zoroastrians, pagans, and persons of other beliefs. ${ }^{338}$ Few of these non-Muslim populations abjured alcohol or pork; indeed, for some (such as Christians) wine was part of their sacred liturgy and culture. ${ }^{339}$ Today, many Muslim countries are religiously pluralistic. ${ }^{340}$ Despite the dastardly violent extremism against non-Muslims in a few countries perpetrated falsely in the name of Islam, the dominant narrative remains one of openness. ${ }^{341}$

That narrative suggests a trade policy of acceptance toward products that, strictly speaking, are forbidden for Muslims to consume, but acceptance at a price-namely, a revenuegenerating tariff. Indeed, the high tariff on alcohol and pork observed in so many Islamic countries might even be analogized loosely to the jizyah (religious tax) that used to be imposed by conquering Islamic forces on non-Muslim dhimmis who had signed a treaty of surrender. ${ }^{342}$ The jizyah, imposed on these non-Muslim conquered peoples in lieu of the zakat, was justified as protection afforded to them by the governing Islamic power, and

335. See Lauran Nielsen, The WTO, Animals and PPMs 313-14 (2007).

336. See Mark S. Copelovitch \& David Ohls, Trade, Institutions, and the Timing of GATT/WTO Accession in Post-Colonial States, 7 Rev. InT'L Orgs. 81 (2012); see Tables.

337. See Modern Muslim Societies 181 (Felicity Crowe et al. eds., Marshall Cavendish 2011).

338. See Michael Nazir-Ali, Islam: A Christian Perspective 127 (1983).

339. See id.

340. See Modernizing Islam: Religion in the Public Sphere in Europe and the Middle East 94 (John L. Esposito \& Francois Burgat eds., 2003).

341. See John Renard, 101 Questions and Answers on Islam 103 (1998)

342. See Bhala, Understanding Islamic LaW (Sharīa), supra note 211, at 1399.

VOL. 47 , NO. 3 


\begin{tabular}{lllll}
\hline$\backslash$ joiprod01\productn $\backslash I \backslash I N L \backslash 47-3 \backslash I N L 302 . t x t$ & unknown & Seq: 37 & 15-MAY-14 & $12: 26$ \\
\hline
\end{tabular}

DIVERSITY WITHIN UNITY

with that protection they carried on their religious and cultural practices. ${ }^{343}$ In brief, a high tariff on alcohol and pork products, like a jizyah, ensures those goods remain Haram for Muslims but allows non-Muslims to carry on. ${ }^{344}$

\section{Moral Relativism?}

As suggested previously, perhaps the most interesting empirical pattern is there is no single one. The Islamic world is not monolithic. ${ }^{345}$ Few Muslim countries, if any, adhere exclusively to the Shari' $a .346$ The Kingdom of Saudi Arabia, Yemen, and Islamic Republic of Iran would be the "purest," in the classical sense. ${ }^{347}$ In contrast, Malaysia and Turkey may look to the Shari'a for inspiration in certain areas of law but are otherwise largely secular countries. ${ }^{348}$ In between these two poles, different Islamic countries fall at different points. ${ }^{349}$

Consequently, each Muslim country defines "public morality" in its own way, in keeping with the insight about Islam that it has unity in diversity but also diversity in unity. 350 Does it mean Muslim countries have fallen victim to moral relativism?

It is worth contemplating what "moral relativism" means. On this topic, a particularly renowned writer, Pope Emeritus Benedict XVI, defines the term as

the notion, widely held today, that there are no absolute truths to guide our lives.

Relativism, by indiscriminately giving value to practically everything, has made "experience" all-important. Yet, experiences, detached from any consideration of what is good or true, can lead, not to genuine freedom, but to moral or intellectual confusion, to a lowering of standards, to a loss of self-respect, and even to despair. ${ }^{351}$

and also,

relativism, that is, letting oneself be "tossed here and there, carried about by every wind of doctrine," seems the only attitude that can cope with modern times. We are building a dictatorship of relativism that does not recognize anything as definitive and whose ultimate goal consists solely of one's own ego and desires. ${ }^{352}$

343. See id.

344. Id. at 449 (listing objects generally considered Haram under Sharī'a), 1237 (regarding alcohol consumption by non-Muslims in Brunei).

345. See Islam Is Not a Monolithic Religion, FaithFreedom, http://www.archive2012 faithfreedom.org/oped/islam-is-not-a-monolithic-religion/ (last visited Mar. 19, 2014).

346. See Table 1.

347. See Table 1.

348. Bhala, UNDERSTANDING Islamic LaW (Sharì'a), supra note 211 , at xxix-xxx, tbl.I:1, at xxxi (differentiating among Muslim countries as to sphere of application of the Shari ${ }^{-} a$ ).

349. See Table 1.

350. See Tables; see also Unity in Diversity, Islamic WORLD ACAD. ScI., http://ias.unimap.edu.my/index.php/ about-msia/unity-in-diversity (last visited Mar. 19, 2014).

351. Pope Benedict XVI, Welcoming Celebration by the Young People Address of his Holiness Benedict XVI (July 17, 2008), available at http://www.vatican.va/holy_father/benedict_xvi/speeches/2008/july/documents/hf_ben-xvi_spe_20080717_barangaroo_en.html.

352. Pope Benedict XVI, Homily of His Eminence Cardinal Joseph Ratzinger, Dean of the College of Cardinals (Apr. 18, 2005), available at http://www.vatican.va/gpII/documents/homily-pro-eligendo-pontifice_ 20050418_en.html.

WINTER 2013 


\begin{tabular}{lllll}
\hline \jciprod01\productn $\backslash I \backslash I N L \backslash 47-3 \backslash I N L 302 . t x t$ & unknown & Seq: 38 & 15-MAY-14 & $12: 26$ \\
\hline
\end{tabular}

Whether moral relativism helps explain the empirical diversity depends in part on the timing of the invocation, i.e., the question is dynamic (time series) but the Tabular data are static (cross-sectional). The answers also depend in part on the outcome of the Arab Spring revolutions and analogous developments outside the Arab region. ${ }^{353}$ Where Muslim countries lie on the spectrum defining the extent to which they adhere to the Sharì $a$ in its classical theory changes over time. ${ }^{354}$

\section{Secularism?}

A fourth explanation is secularism. Notwithstanding the diversity within the unity of the Islamic world, the considerable variations among Muslim countries as to their trade policies on Haram goods might reflect a lack of interest in drafting and enforcing a "Muslim" trade policy. Even though political and religious leaders in these countries may profess formal adherence to the precepts of Islam, as a practical matter, many people in them are secular in outlook. ${ }^{355}$ That certainly is true in "Christian" America, "Buddhist" Korea, or "Hindu" India. 356

That is not to say people in these countries are not devout. Quite the contrary-sincere devotion knows no geopolitical boundaries. Rather, it is to say many people in Muslim (and non-Muslim) countries regard religion as a personal, private matter. ${ }^{357}$ So, the choice of consumption of alcohol or pork products is between the disciple and God (Allah), not a matter for trade policy via an import ban.

If secularism is an explanation for the trade policy of Muslim countries toward alcohol and pork products, then perhaps it is wrong to think of them as "Muslim" in the first place. To typecast them as religious is unfair, because they do not try to inject strict Islamic precepts in their Tariff Schedules any more than Christian countries try to inject Gospel teachings in theirs. Both groups of countries are secular in their trade outlook; for all of them, setting and adjusting tariffs is a matter of political economy. ${ }^{358}$ They consider what is in their comparative advantage, in the context of domestic constituencies (especially producers of like products) that lobby for protection. 359

The term "secularism" requires definition. Among those who have thought about its meaning and effects are Pope Emeritus Benedict XVI and Pope Francis. ${ }^{360}$ Muslim

353. See generally Paul Freston, Examining Religious Diversity and Influence in the Arab Spring, CENTRE FOR INT'L GOVERnANCE INNOvation (Nov. 15, 2011), http://www.cigionline.org/articles/2011/11/examiningreligious-diversity-and-influence-arab-spring.

354. See Sharia, Teaching Tolerance, http://www.tolerance.org/publication/sharia (last visited Mar. 19, 2014).

355. See Table 1.

356. See How Many Americans Are Secular?, Humanism, http://www.andrewaasmith.com/Humanism/ howmany.html (last visited Mar. 19, 2014); Religion, KOREA.NET, http://www.korea.net/AboutKorea/KoreanLife/Religion (last visited Mar. 19, 2014); World Factbook: Religions, supra note 219.

357. See, e.g., Jane Strum, Letter to the Editor, Religion is a Personal Matter, Columbia (Mar. 27, 2012, 6:00 AM), http://www.columbian.com/news/2012/mar/27/letter-religion-personal-matter.

358. See Subcommittee on Unfair Trade Policies and Measures, supra note 247.

359. Id.

360. See Pope Benedict XVI, Welcoming Celebration by the Young People Address of his Holiness Benedict XVI, supra note 351. See generally Pope Francis, Apostolic Exhortation Evangeli Gaudium of ThE Holy Father Francis to the Bishops, Clergy, Consecrated Persons and the Lay Faithful on the Proclamation of the Gospel in Today's World (2013), available at http://www.vatican.va/holy_

VOL. 47 , NO. 3 


\begin{tabular}{|c|c|c|c|}
\hline 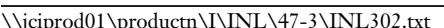 & unknown & Seg: 39 & 15-MAY-14 \\
\hline
\end{tabular}

DIVERSITY WITHIN UNITY

clergy, too, worry about secularism undermining commitment to religious values. ${ }^{361}$ But, at least in the non-Muslim English-speaking world, these two leaders have garnered considerable attention for their work. ${ }^{362}$ In his 224-page November 2013 Apostolic Exhortation, Evangelii Gaudium (The Foy of the Gospel), Pope Francis explains that secularization has eroded ethical values, creating a sense of disorientation and superficiality. ${ }^{363} \mathrm{He}$ states,

by completely rejecting the transcendent, [secularism] has produced a growing deterioration of ethics, a weakening of the sense of personal and collective sin, and a steady increase in relativism. These have led to a general sense of disorientation, especially in the periods of adolescence and young adulthood which are so vulnerable to change. As the bishops of the United States of America have rightly pointed out, while the Church insists on the existence of objective moral norms which are valid for everyone, "there are those in our culture who portray this teaching as unjust, that is, as opposed to basic human rights. Such claims usually follow from a form of moral relativism that is joined, not without inconsistency, to a belief in the absolute rights of individuals." 364

In sum, the fourth explanation is that Muslim and non-Muslim countries alike are influenced by secular trends when forging their trade policies. ${ }^{365}$ The result is not a pure, single-minded dedication to writing and implementing religiously-based trade measures, but rather what might be dubbed a materialistic policy.

\section{Future Options}

By no means is an OIC-WTO Member stuck with a binding to which it committed on a Haram good. 366 Any WTO Member, with respect to any bound rate on any product category, has a legal right under GATT Articles XXVII and XXVIII to increase or otherwise alter that rate. ${ }^{367}$ But these Articles contain requirements that must be followed. ${ }^{368}$

Briefly, a Member seeking modification must negotiate or consult with other Members, particularly those with a principal supplying interest, or a substantial interest, in the product for which tariff alteration is sought. ${ }^{369}$ They are to seek agreement on compensatory adjustments, meaning that if the Member raises barriers on alcohol or pork, then it should

father/francesco/apost_exhortations/documents/papa-francesco_esortazione-ap_20131124_evangeliigaudium_en.pdf.

361. Mehmet Görmez, Religion and Secularism in the Modern World: A Turkish Perspective (Mar. 2012), available at http://sam.gov.tr/religion-and-secularism-in-the-modern-world-a-turkish-perspective; John L. Esposito, Rethinking Islam and Secularism, 10-13, 17 (2010).

362. Id.

363. Pope Francis, supra note 360 .

364. Id. II 64.

365. See Irfan-ul-Haque et al., Trade, Technology, and International Competitiveness 20 (1995).

366. See Types of Tariffs, WORLD BANK, http://wits.worldbank.org/WITS/wits/WITSHELP/Content/Data Retrieval/P/Intro/C2.Types_of_Tariffs.htm (last visited Mar. 19, 2014).

367. GATT arts. XXVII, XXVIII.

368. For a detailed discussion of adjusting tariff schedules, see BHALA, MODERn GATT LAw, supra note 82, ch. 25.

369. See GATT art. XXVIII.

WINTER 2013 
lower barriers on another or other products. ${ }^{370}$ After all, the Member is withdrawing a concession it previously made on a Haram good, so it needs to "pay" with a new and different concession. If no agreement is reached, then the other Member or Members may retaliate against the modifying Member by withdrawing substantially equivalent concessions to their trade with it. ${ }^{371}$

To conclude, Islam is a unifying force bringing together fifty-seven countries in the OIC, thirty-four of which hold WTO Membership and have Muslim majority populations. Islam has unifying precepts-most essentially, monotheism, the belief in a Day of Judgment, and the view that God (Allah) intervenes in human history; and most practically, the Five Pillars. That Muslim countries regard certain goods as forbidden under the Shari'a bespeaks a unity. But Islam and its legal system hardly are monolithic. That they have different international trade laws and policies on Haram goods shows their rich diversity.

370. See id.

371. See id.

VOL. 47 , NO. 3 


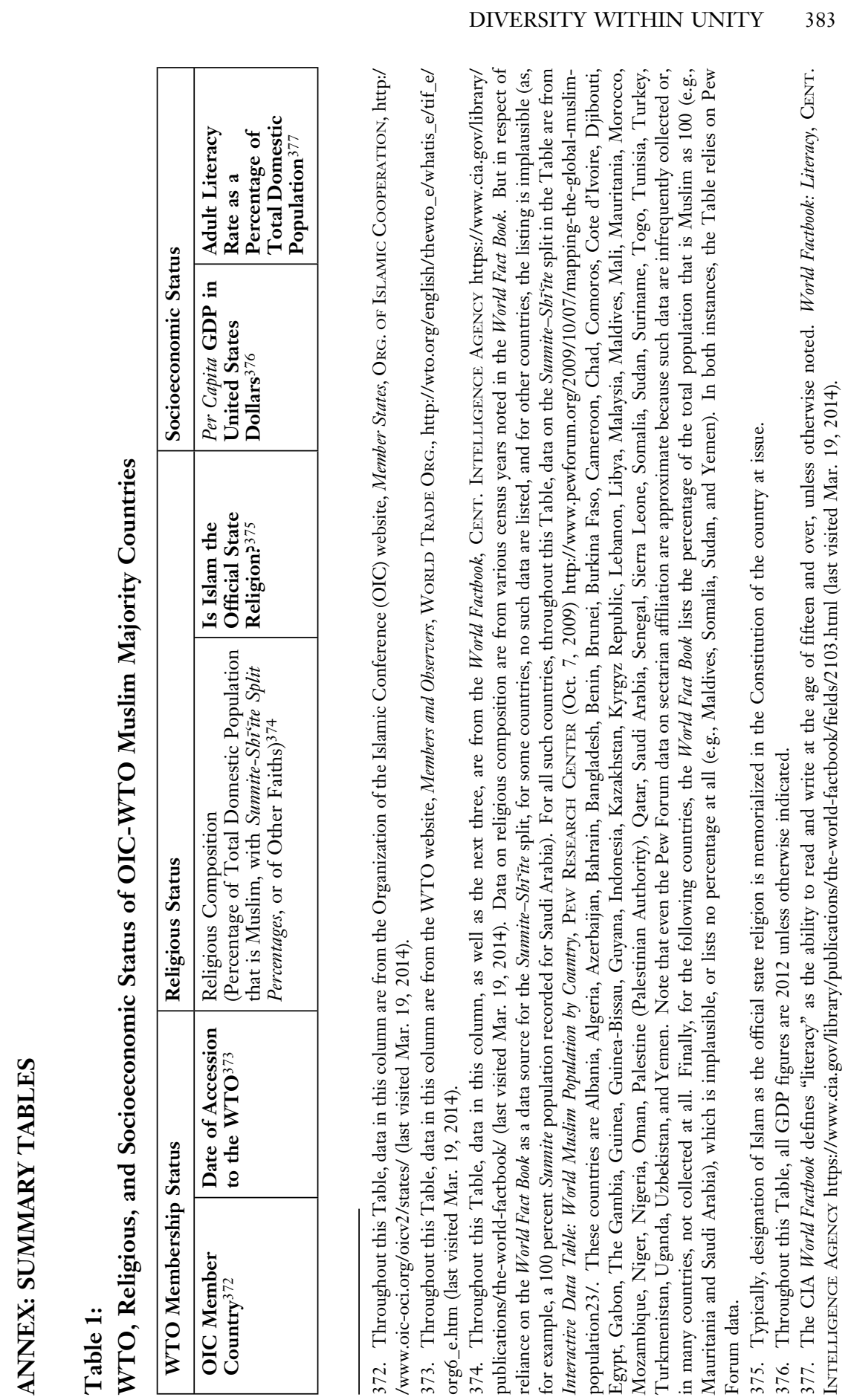

WINTER 2013 
384 THE INTERNATIONAL LAWYER

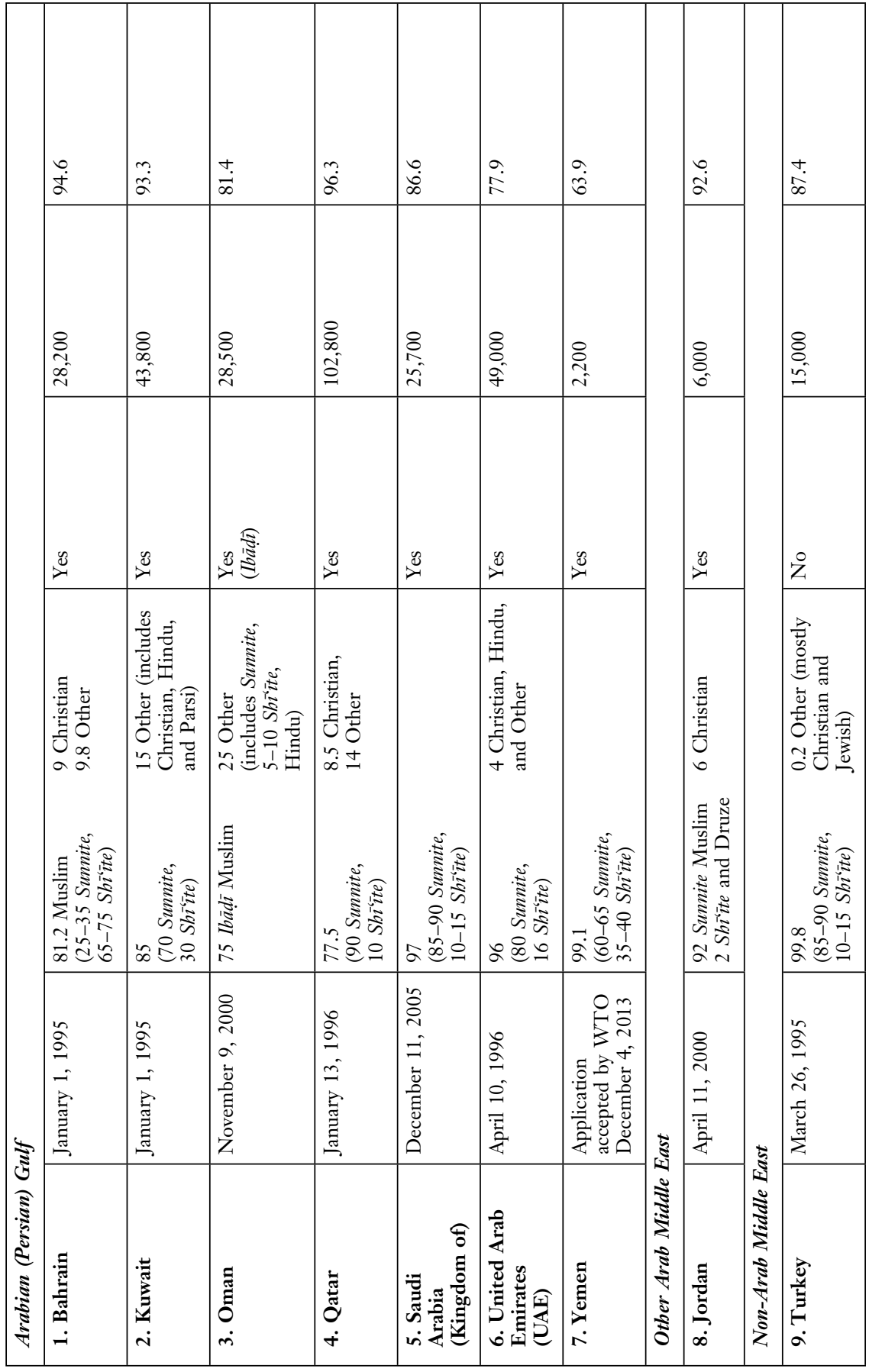

VOL. 47 , NO. 3 
DIVERSITY WITHIN UNITY 385

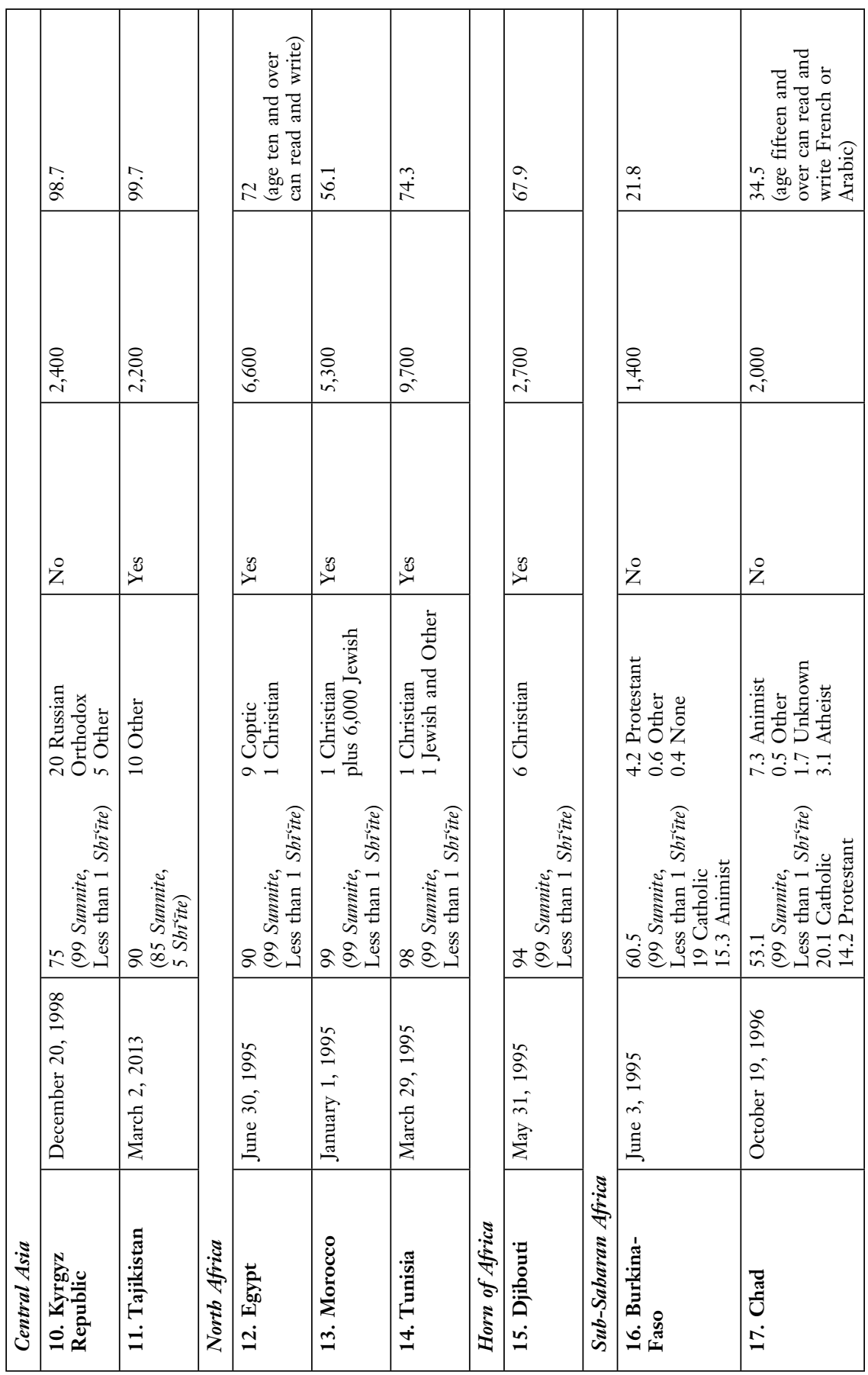

WINTER 2013 
386 THE INTERNATIONAL LAWYER

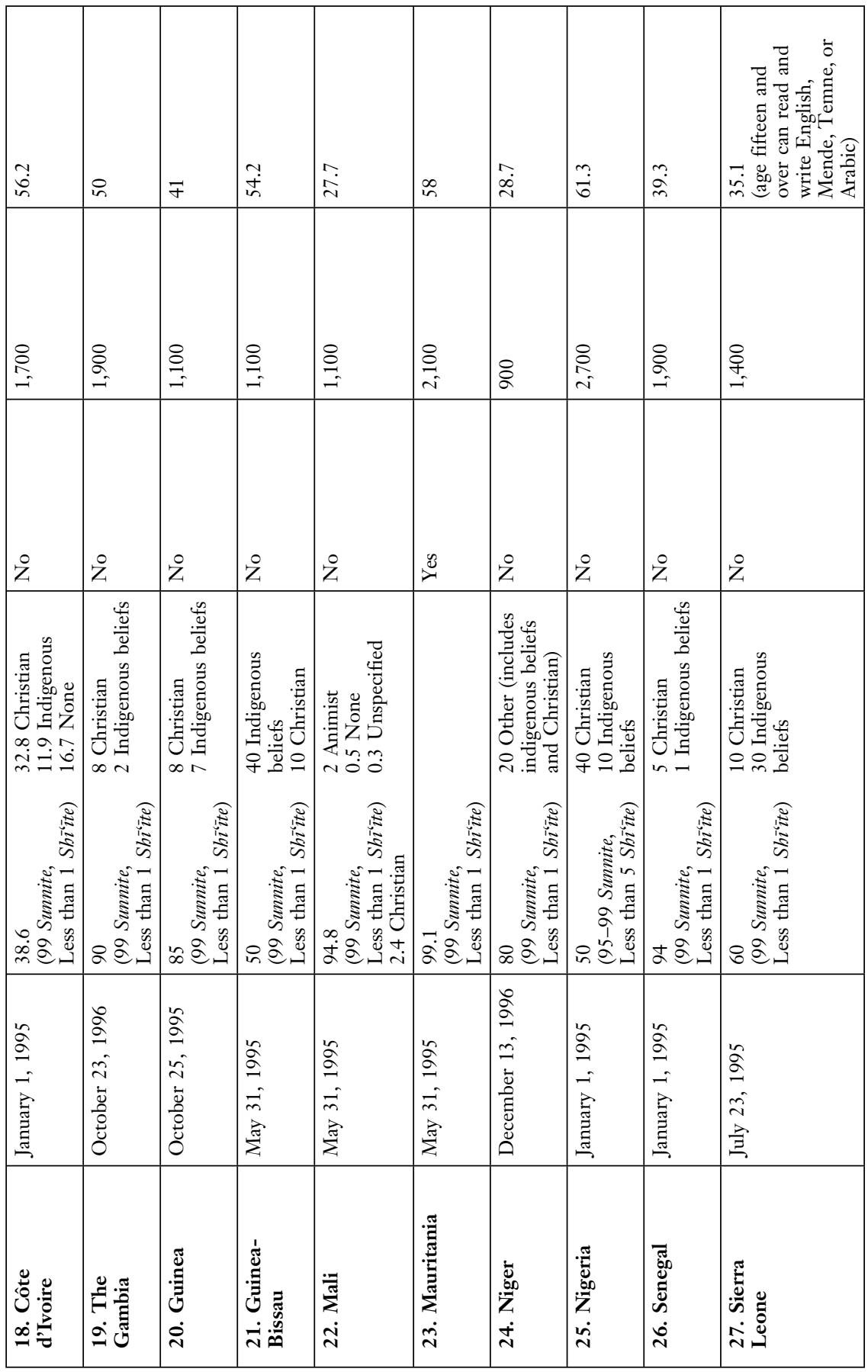

VOL. 47 , NO. 3 


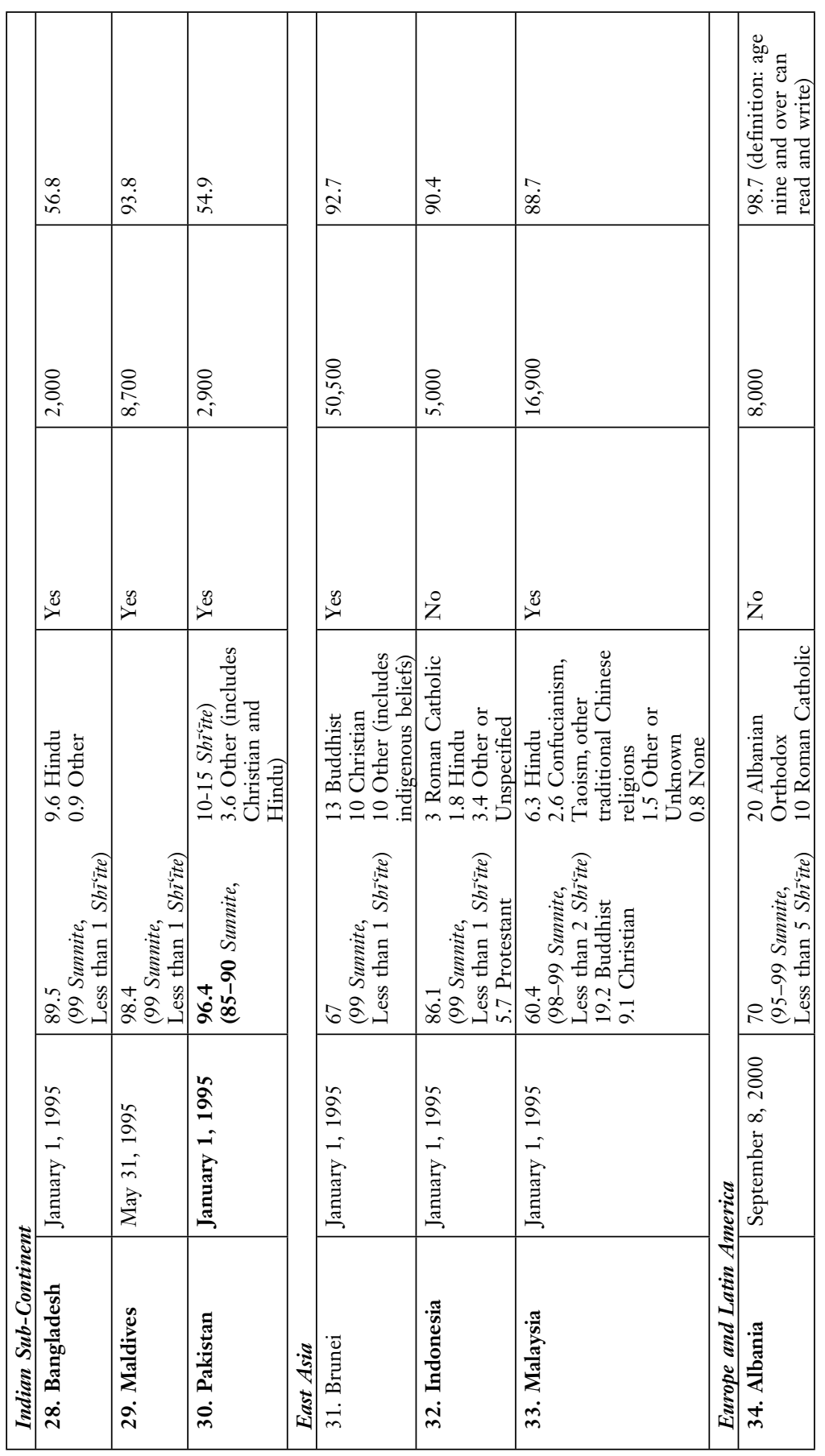

WINTER 2013 


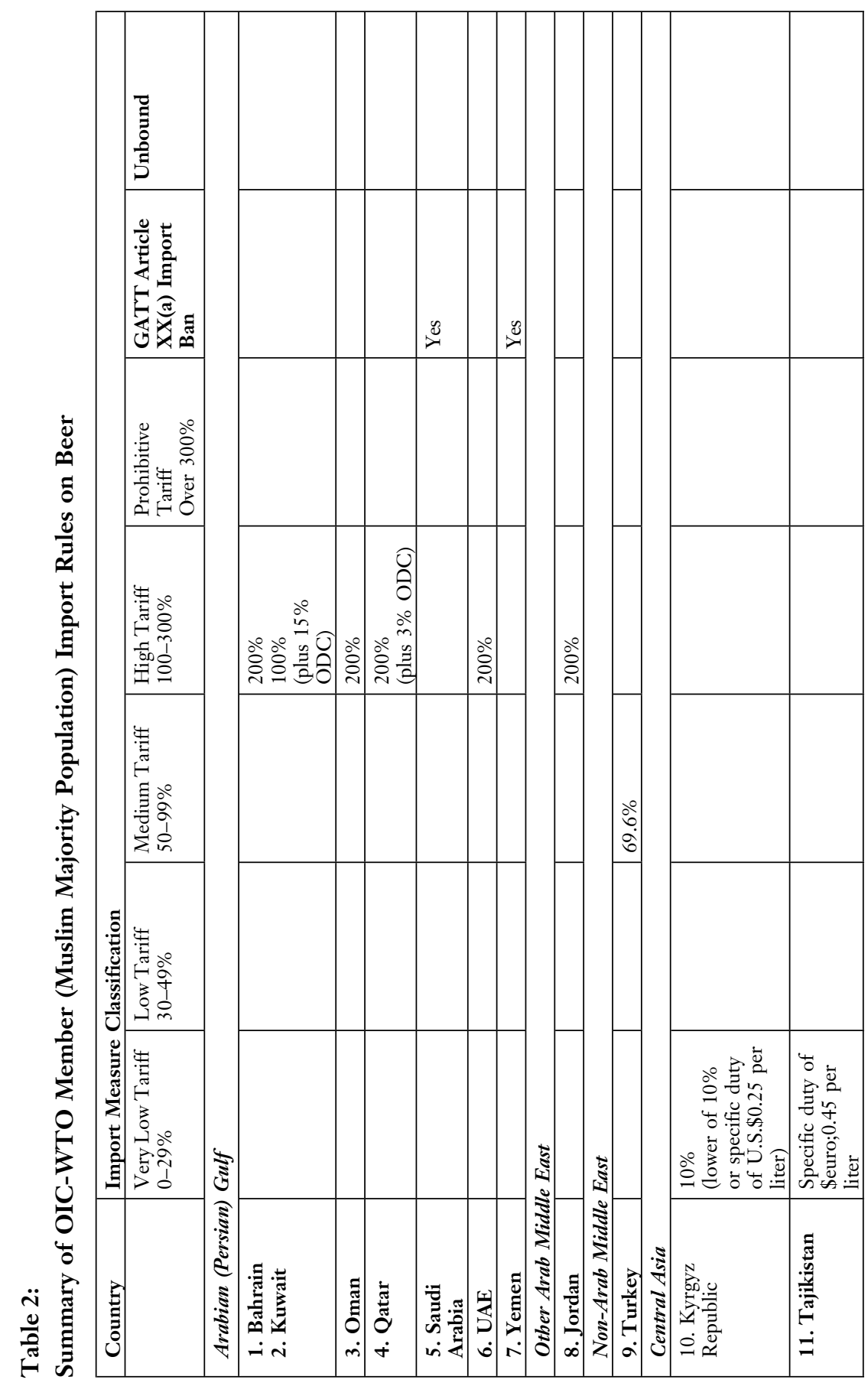

VOL. 47 , NO. 3 
DIVERSITY WITHIN UNITY

389

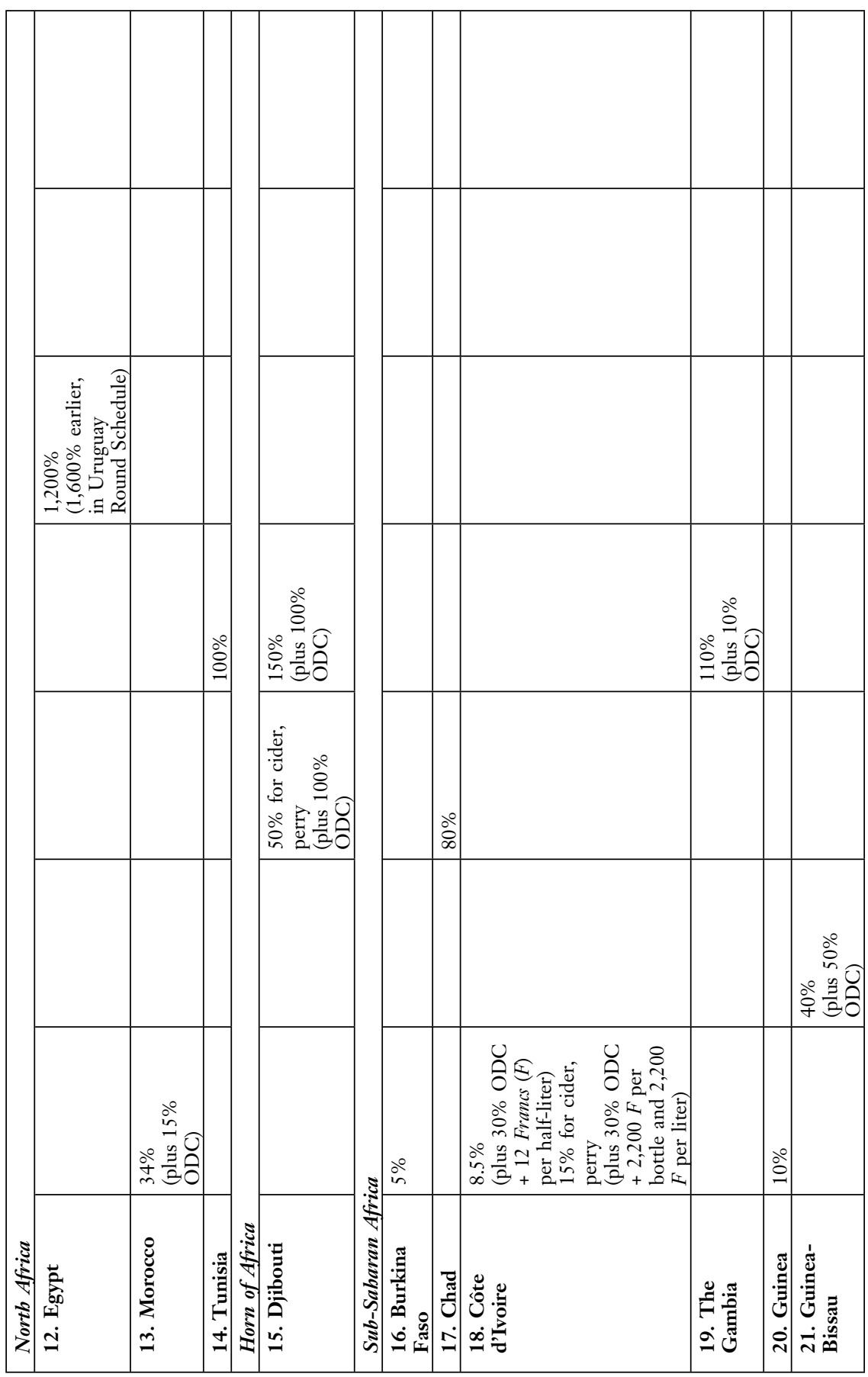

WINTER 2013 
390 THE INTERNATIONAL LAWYER

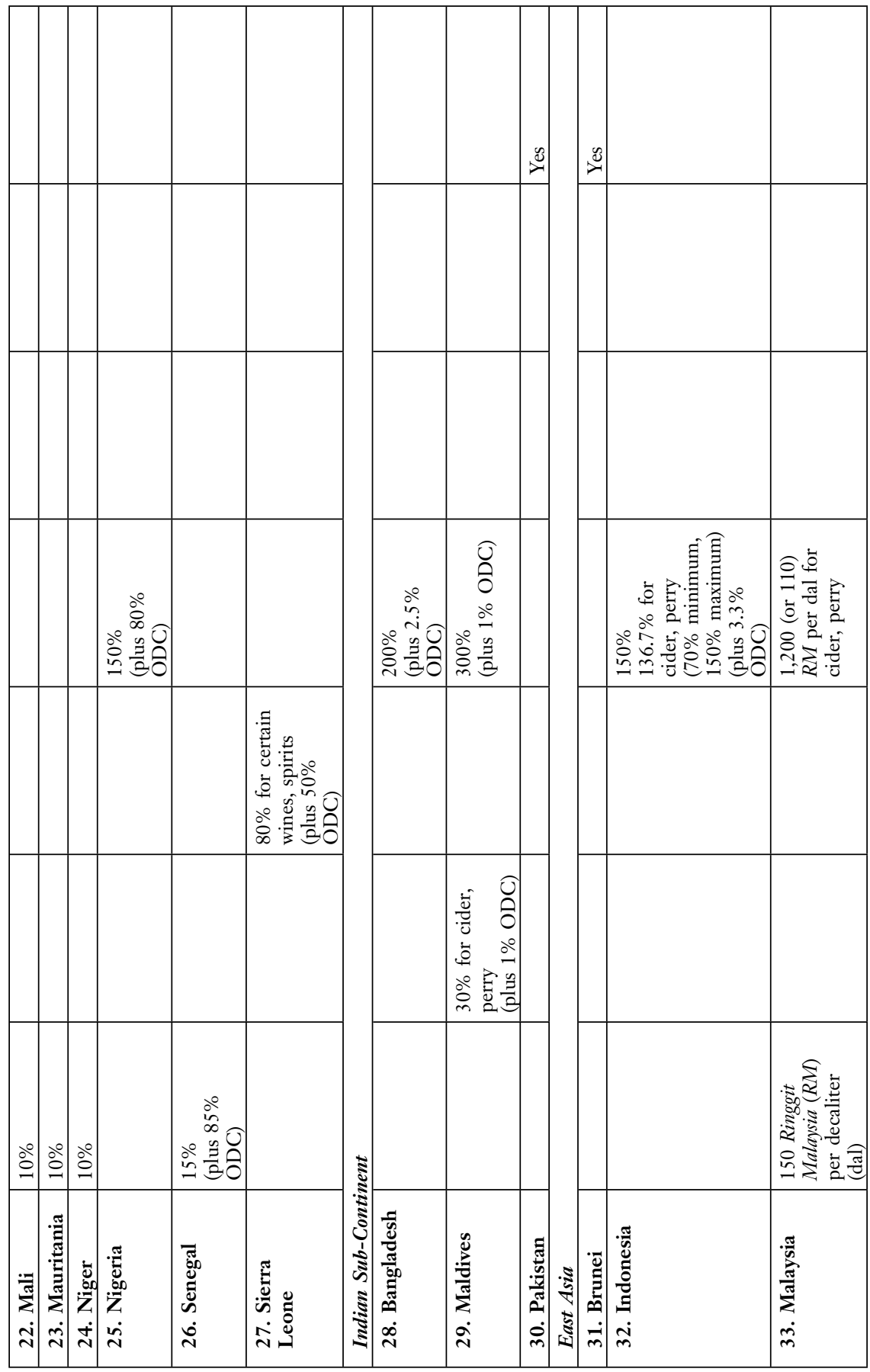

VOL. 47 , NO. 3 
DIVERSITY WITHIN UNITY

391

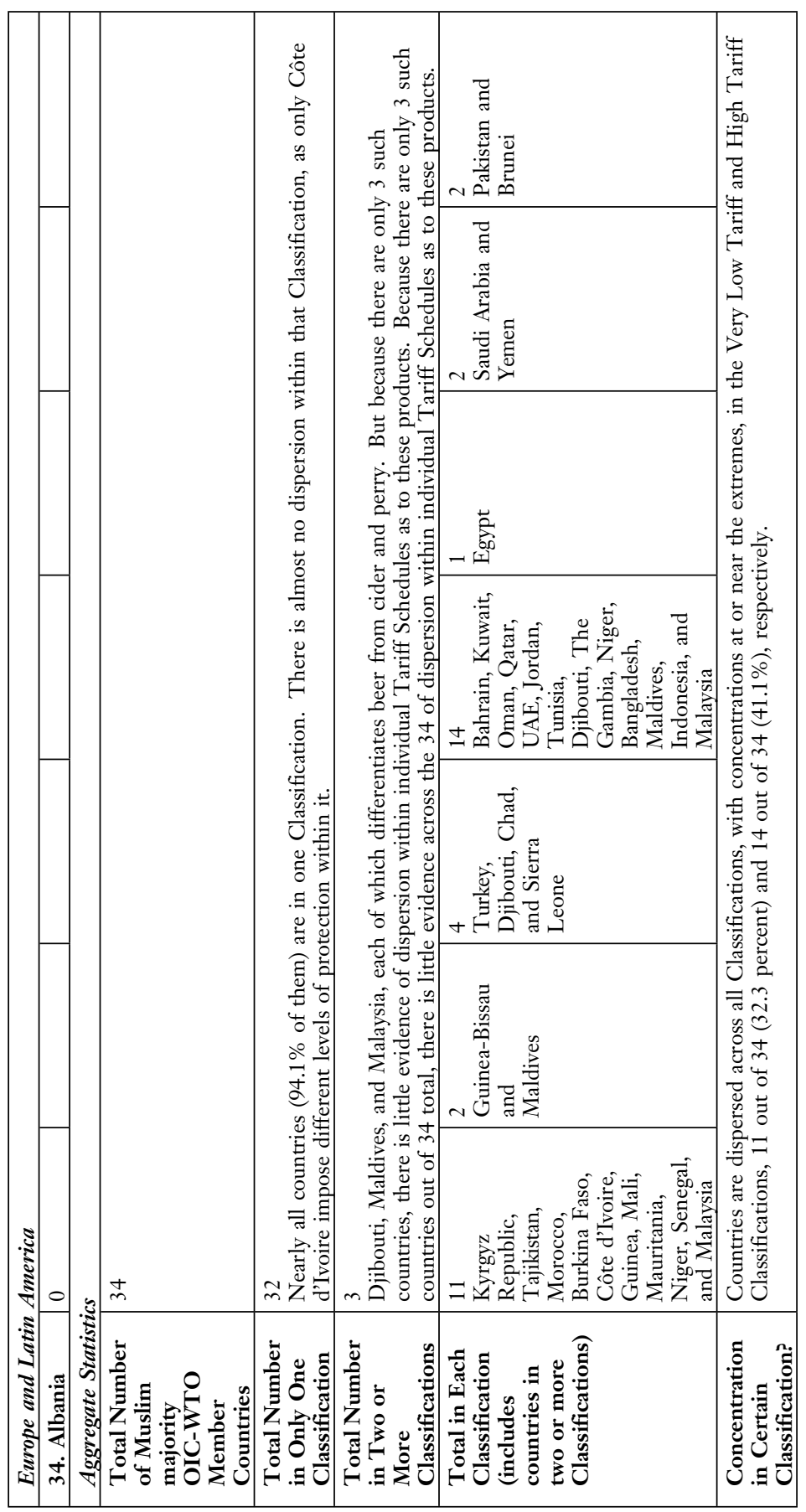

WINTER 2013 


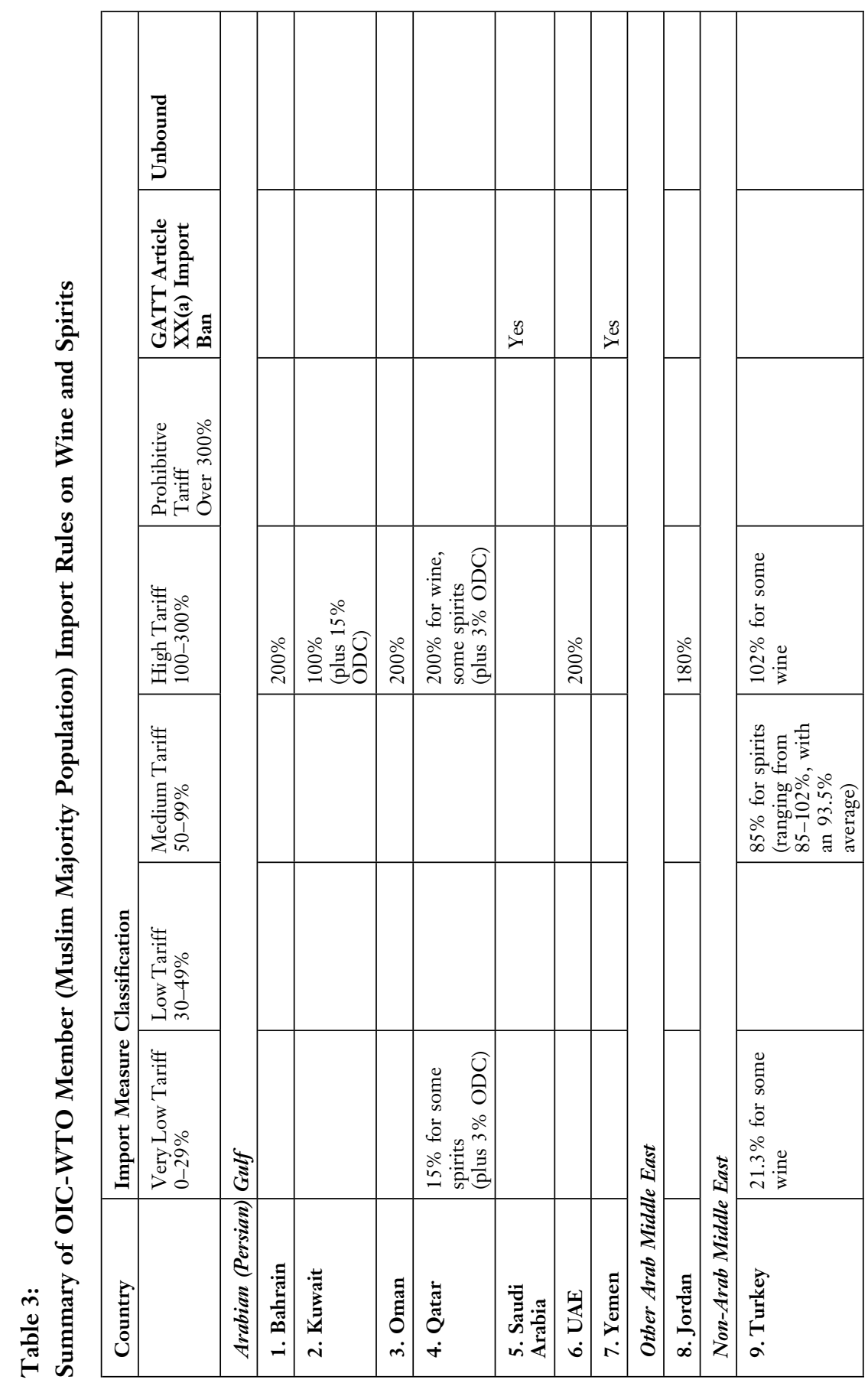

VOL. 47 , NO. 3 
DIVERSITY WITHIN UNITY

393

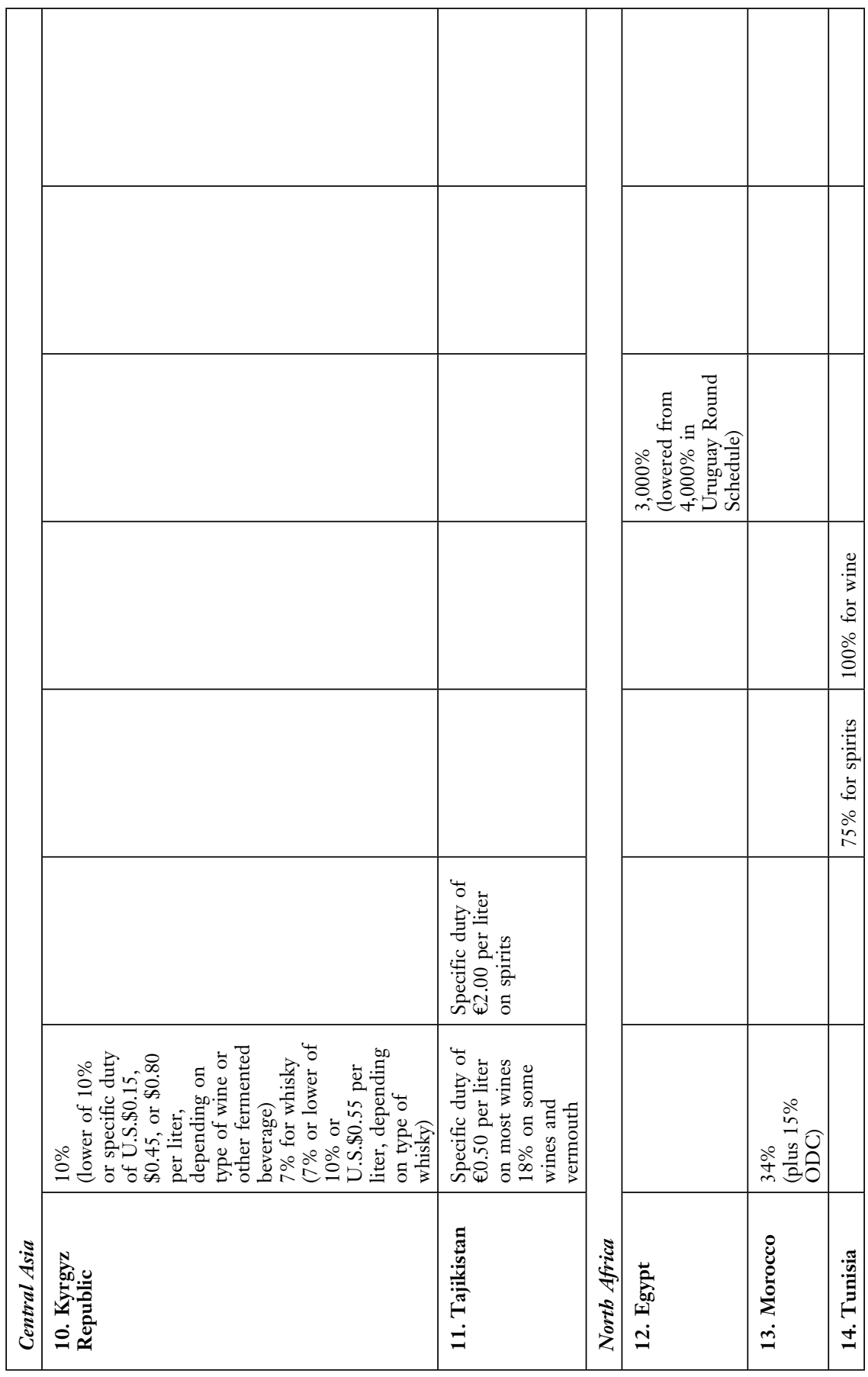

WINTER 2013 
394 THE INTERNATIONAL LAWYER

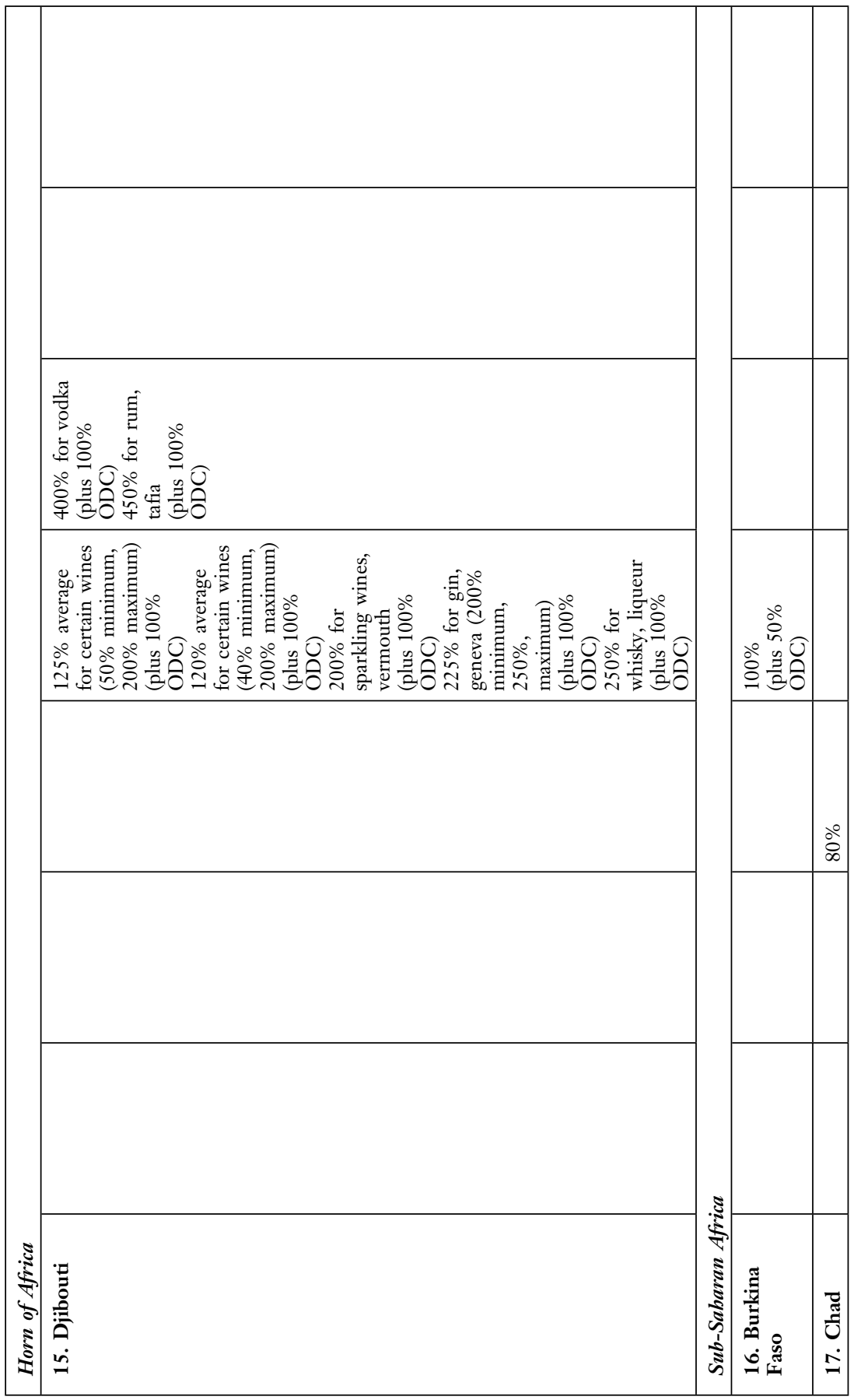

VOL. 47 , NO. 3 
DIVERSITY WITHIN UNITY

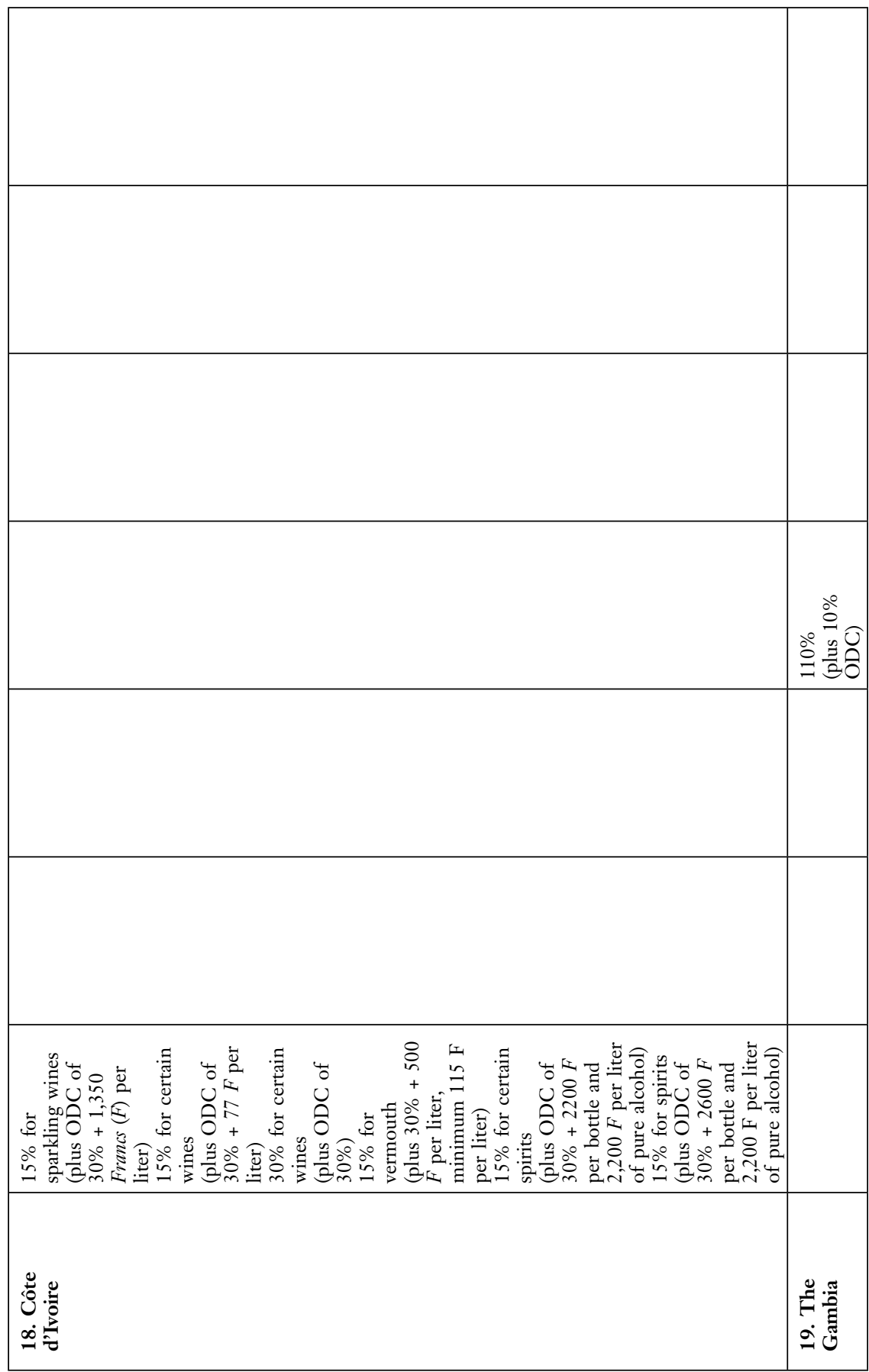

WINTER 2013 
396 THE INTERNATIONAL LAWYER

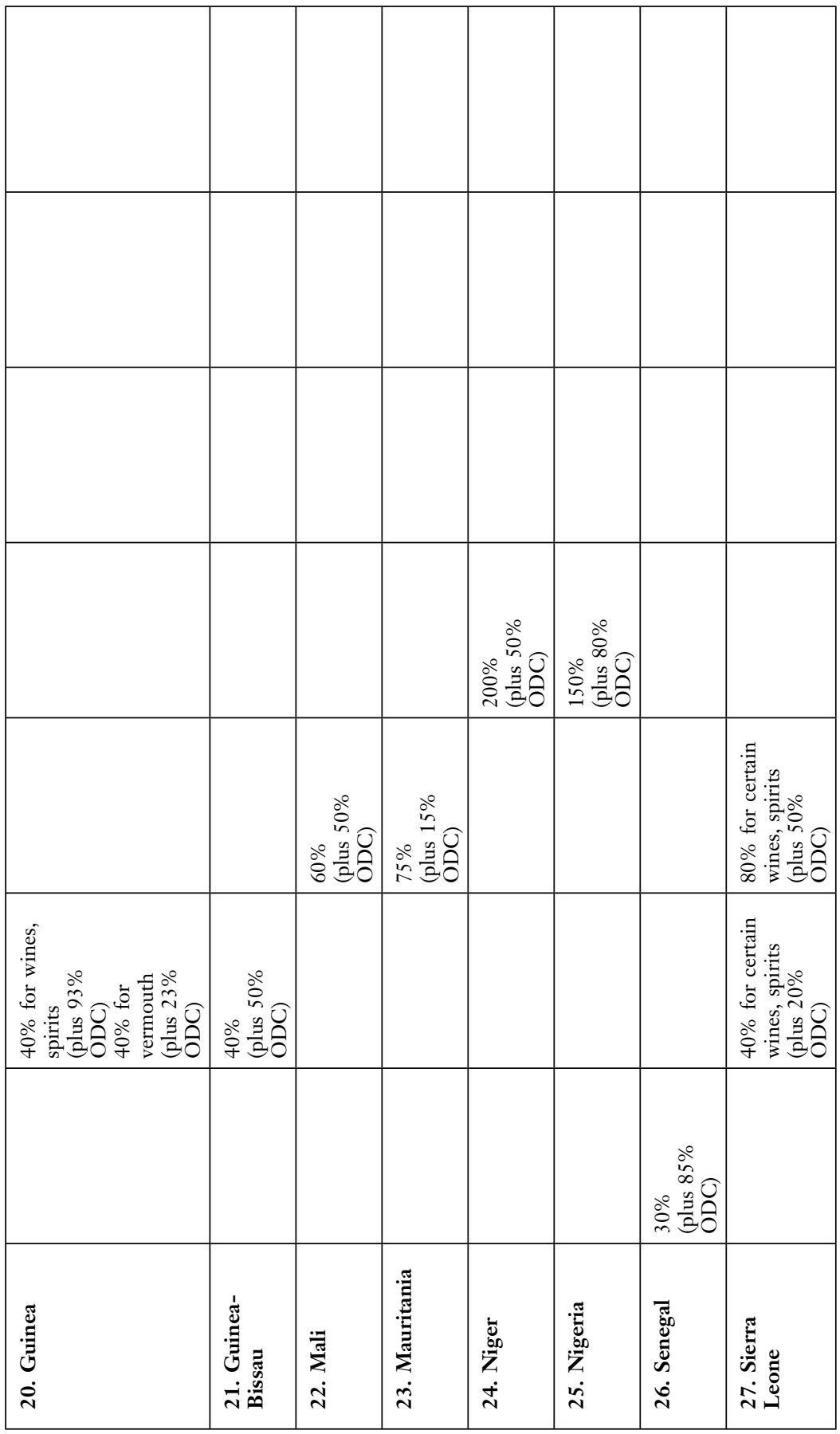

VOL. 47 , NO. 3 
DIVERSITY WITHIN UNITY

397

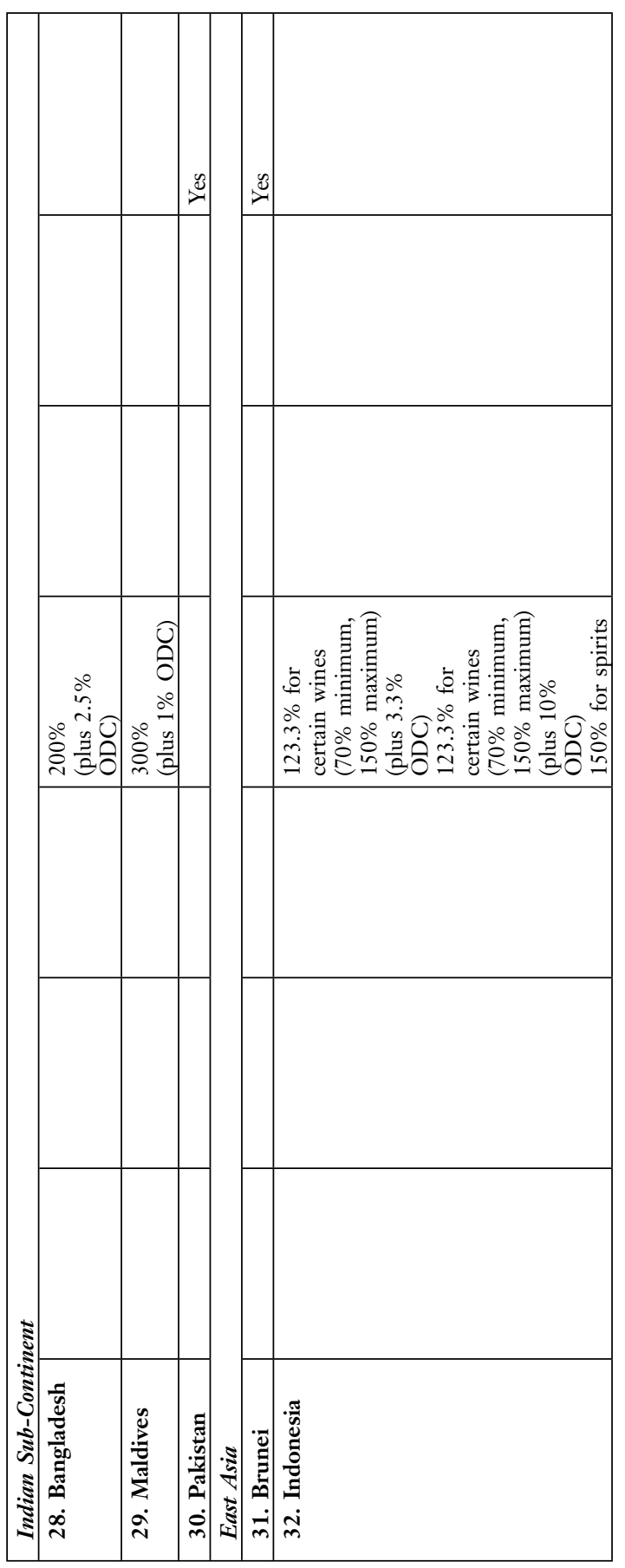

WINTER 2013 


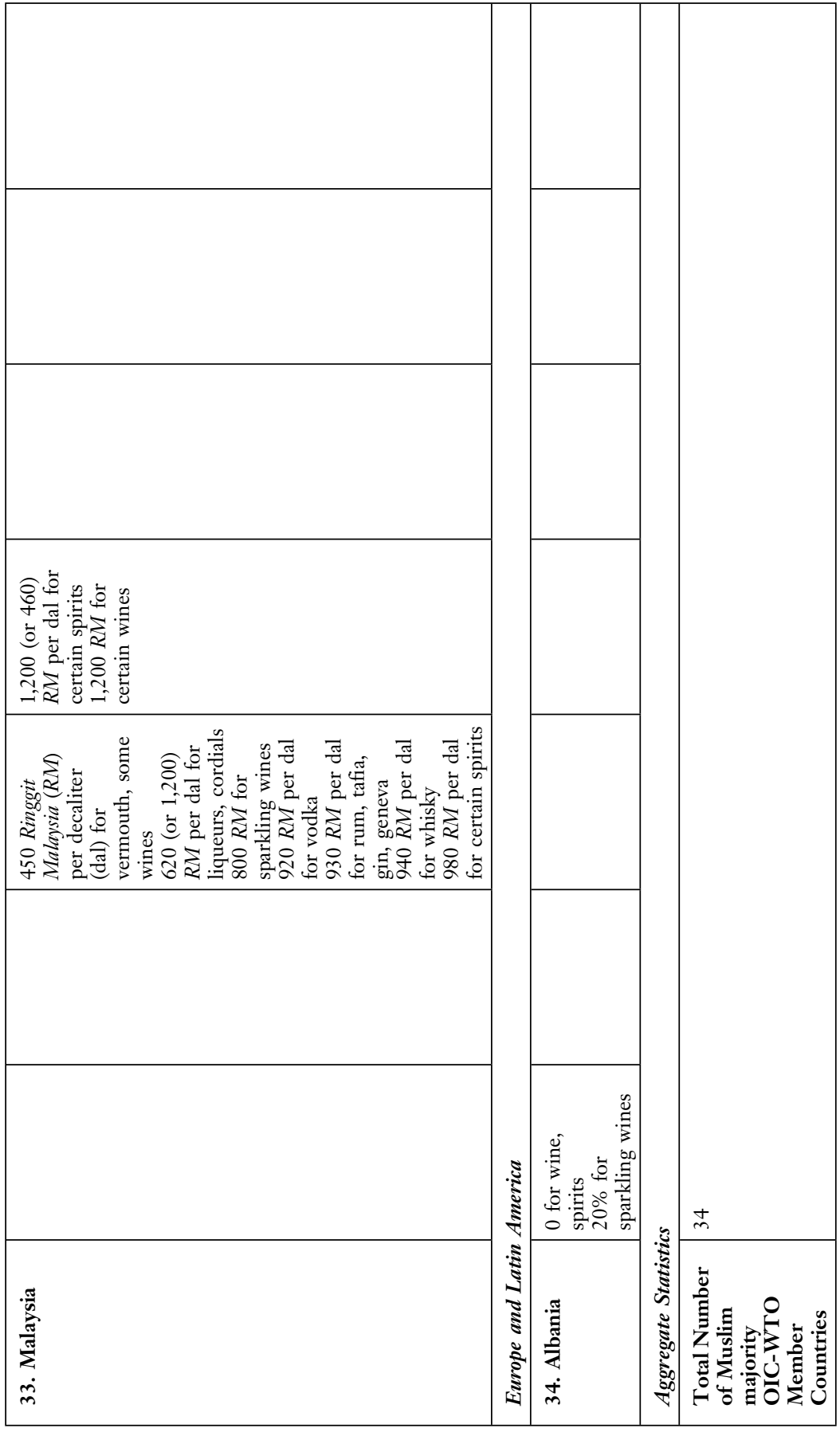

VOL. 47 , NO. 3 
DIVERSITY WITHIN UNITY 399

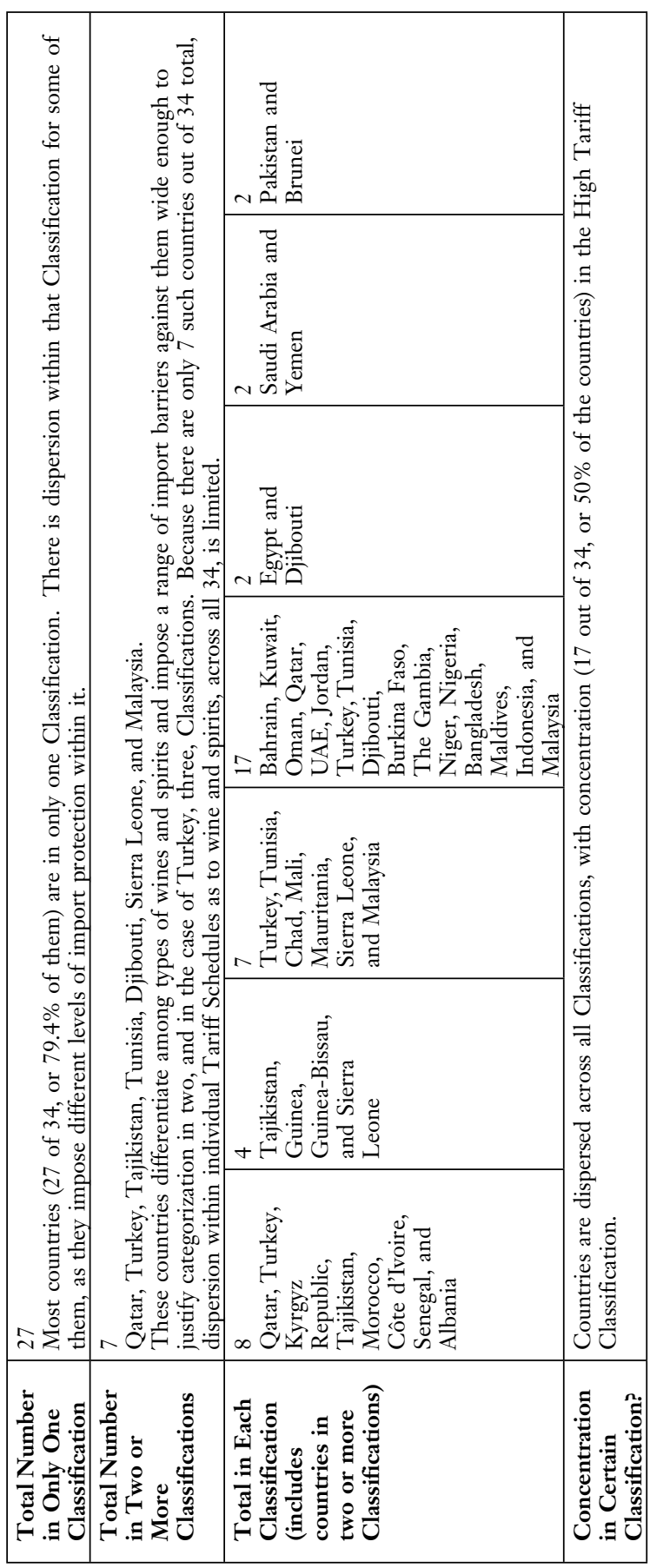

WINTER 2013 


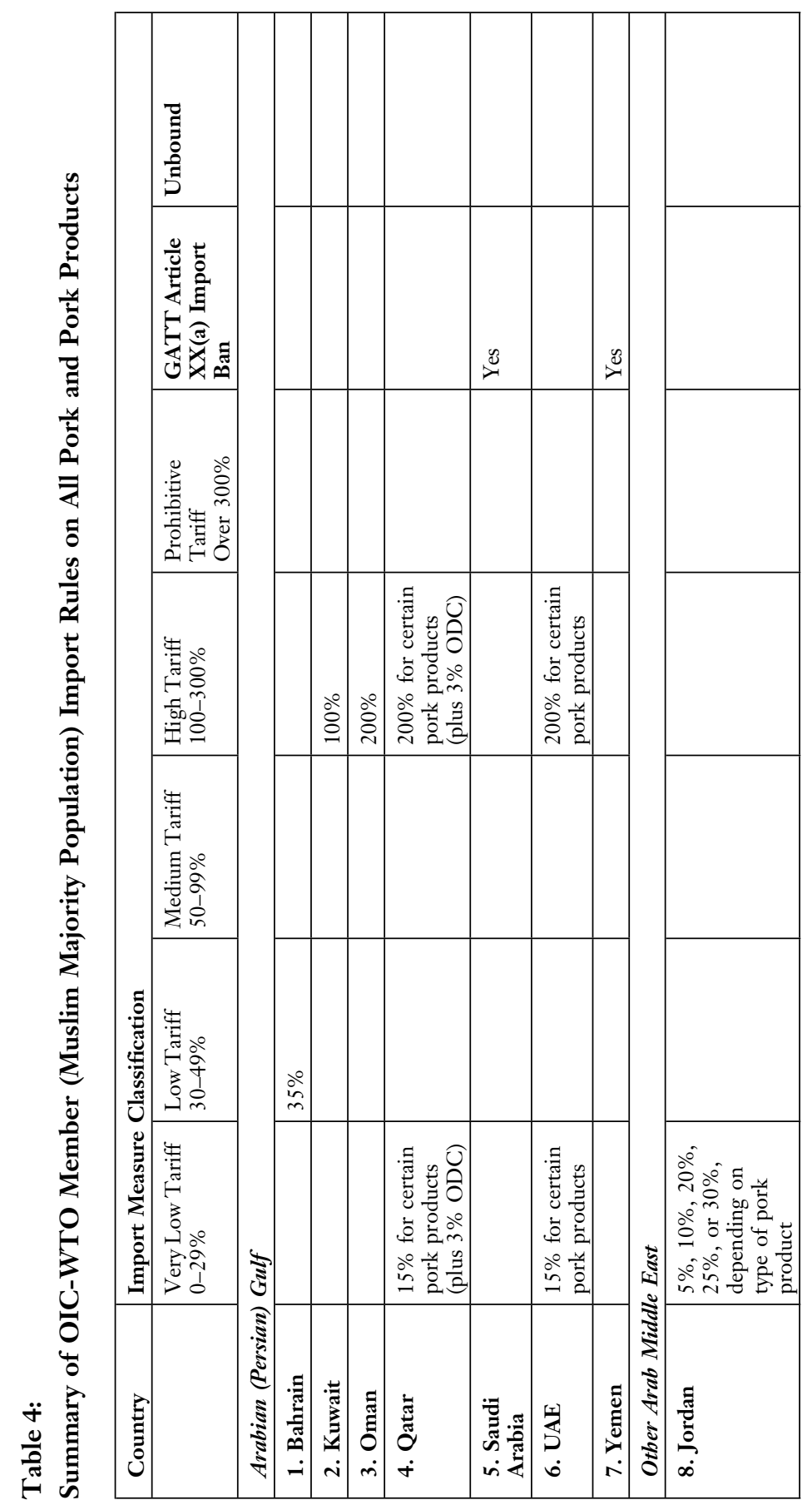

VOL. 47 , NO. 3 


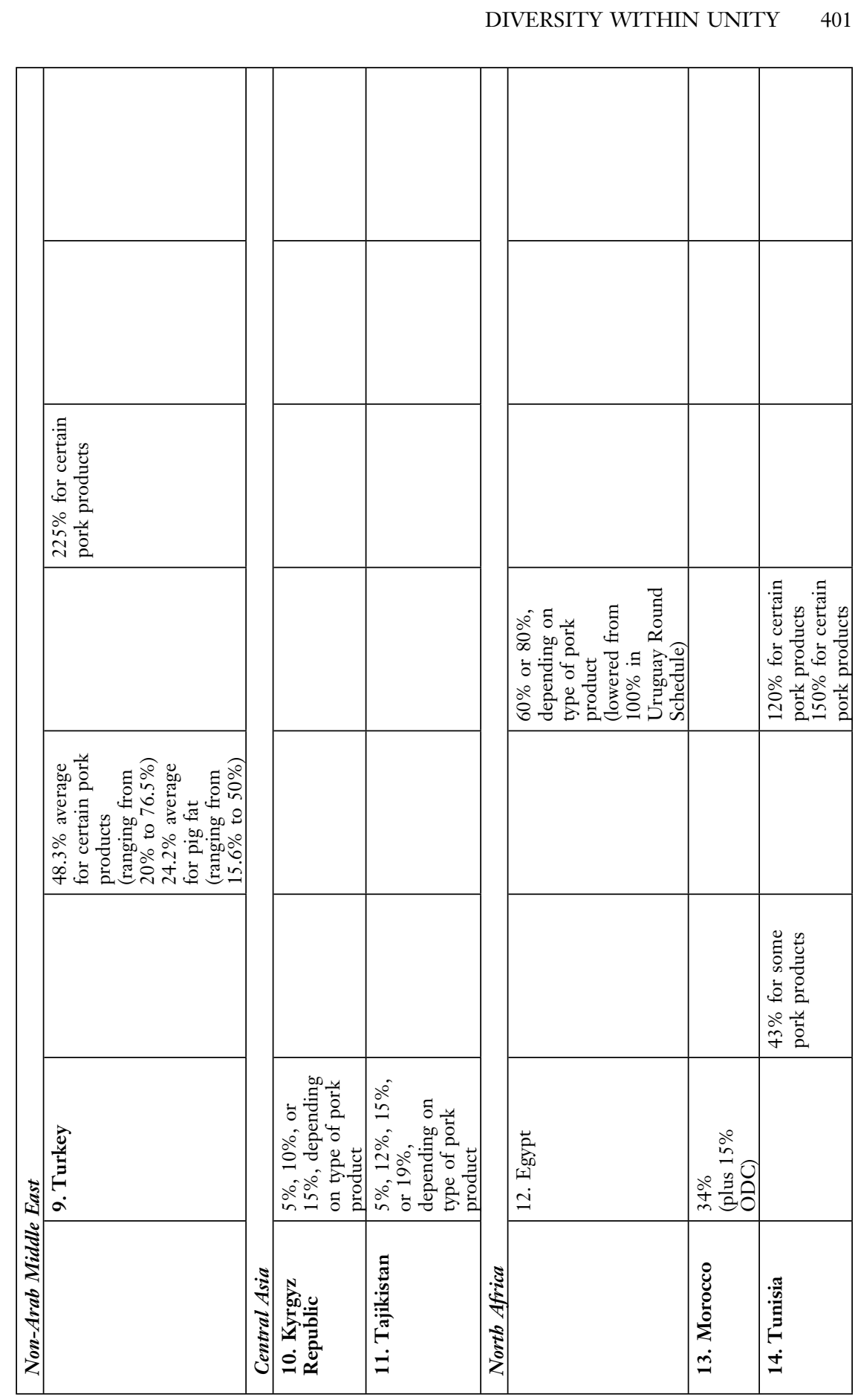

WINTER 2013 
402 THE INTERNATIONAL LAWYER

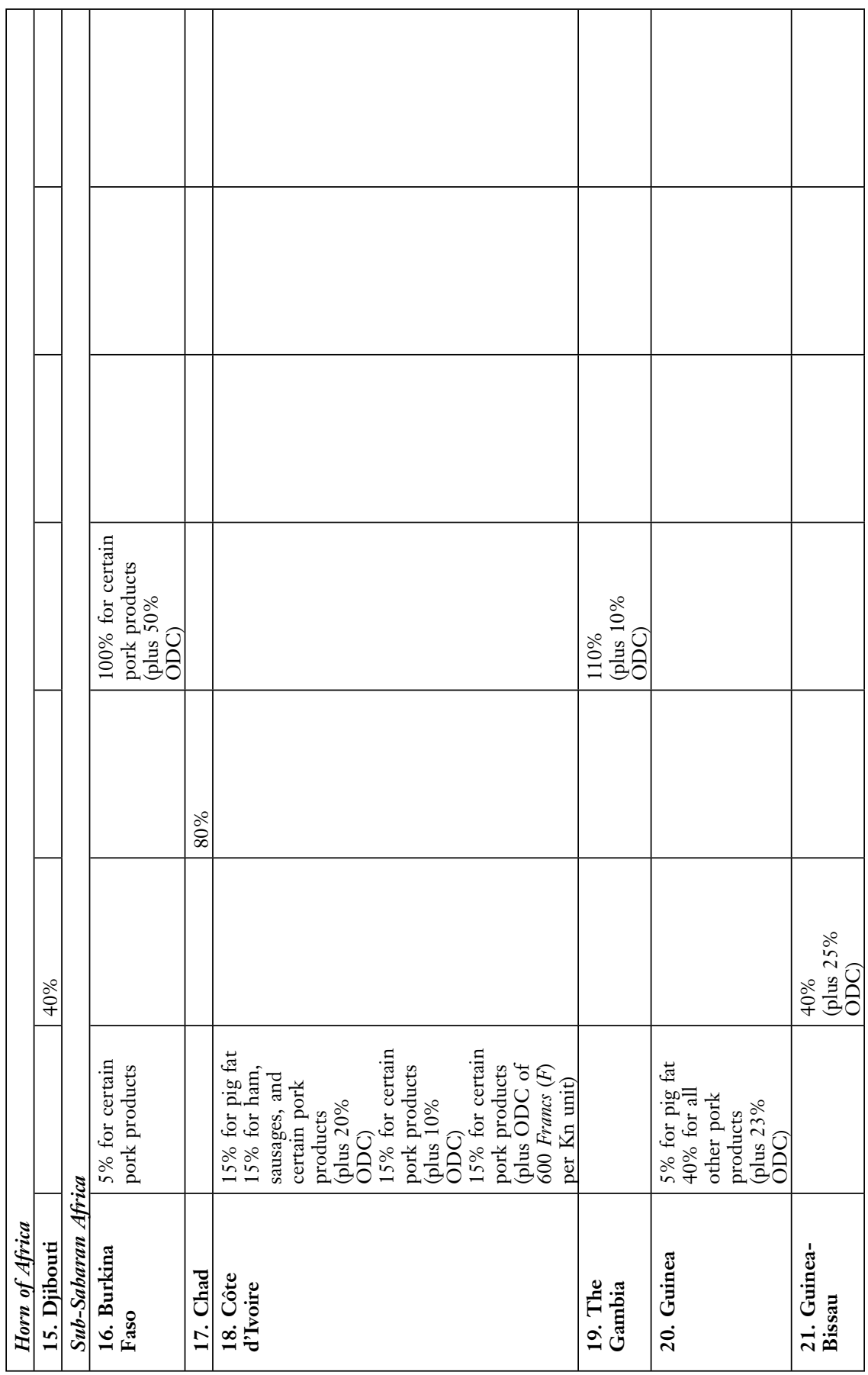

VOL. 47 , NO. 3 
DIVERSITY WITHIN UNITY

403

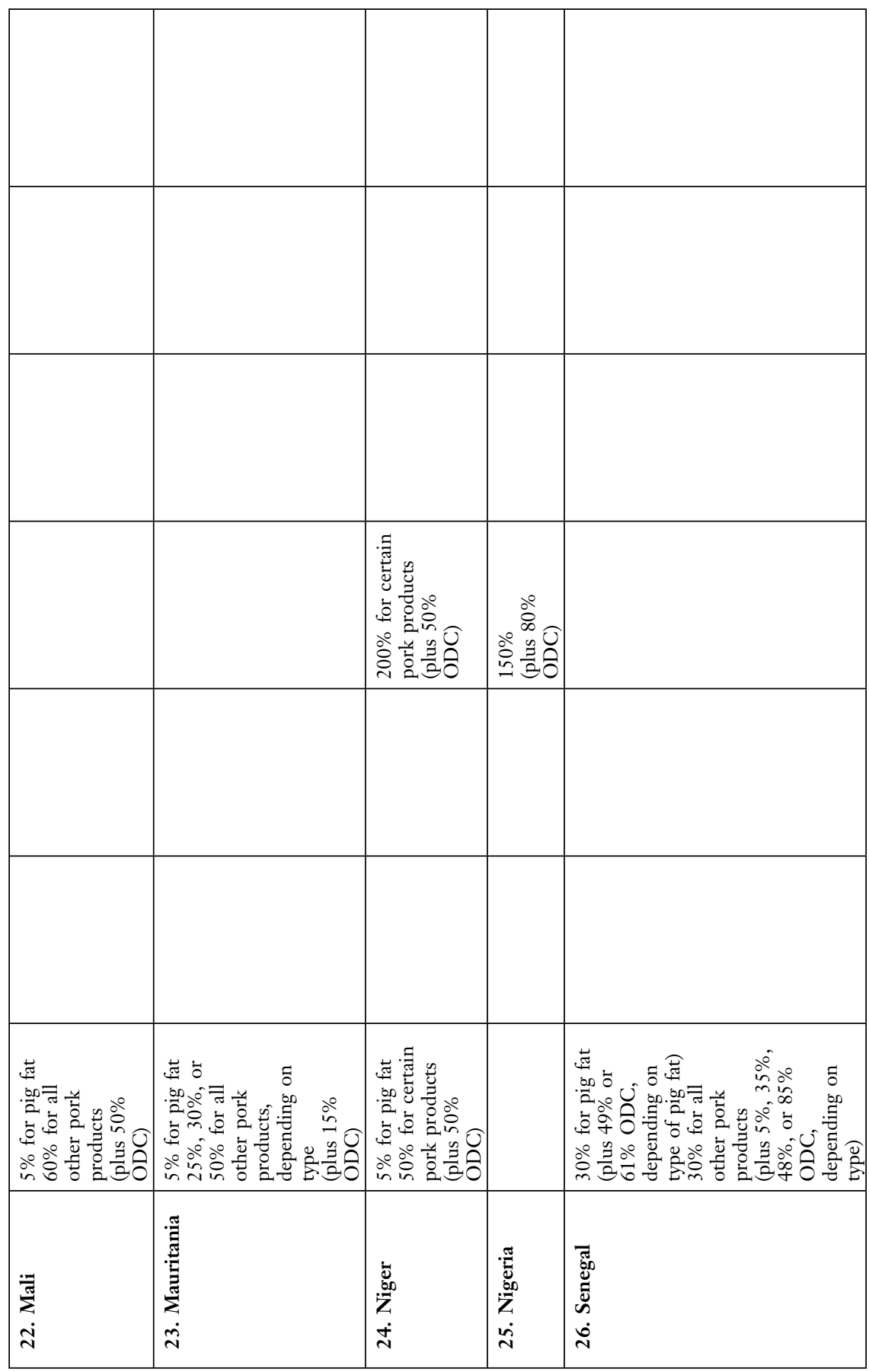

WINTER 2013 
404 THE INTERNATIONAL LAWYER

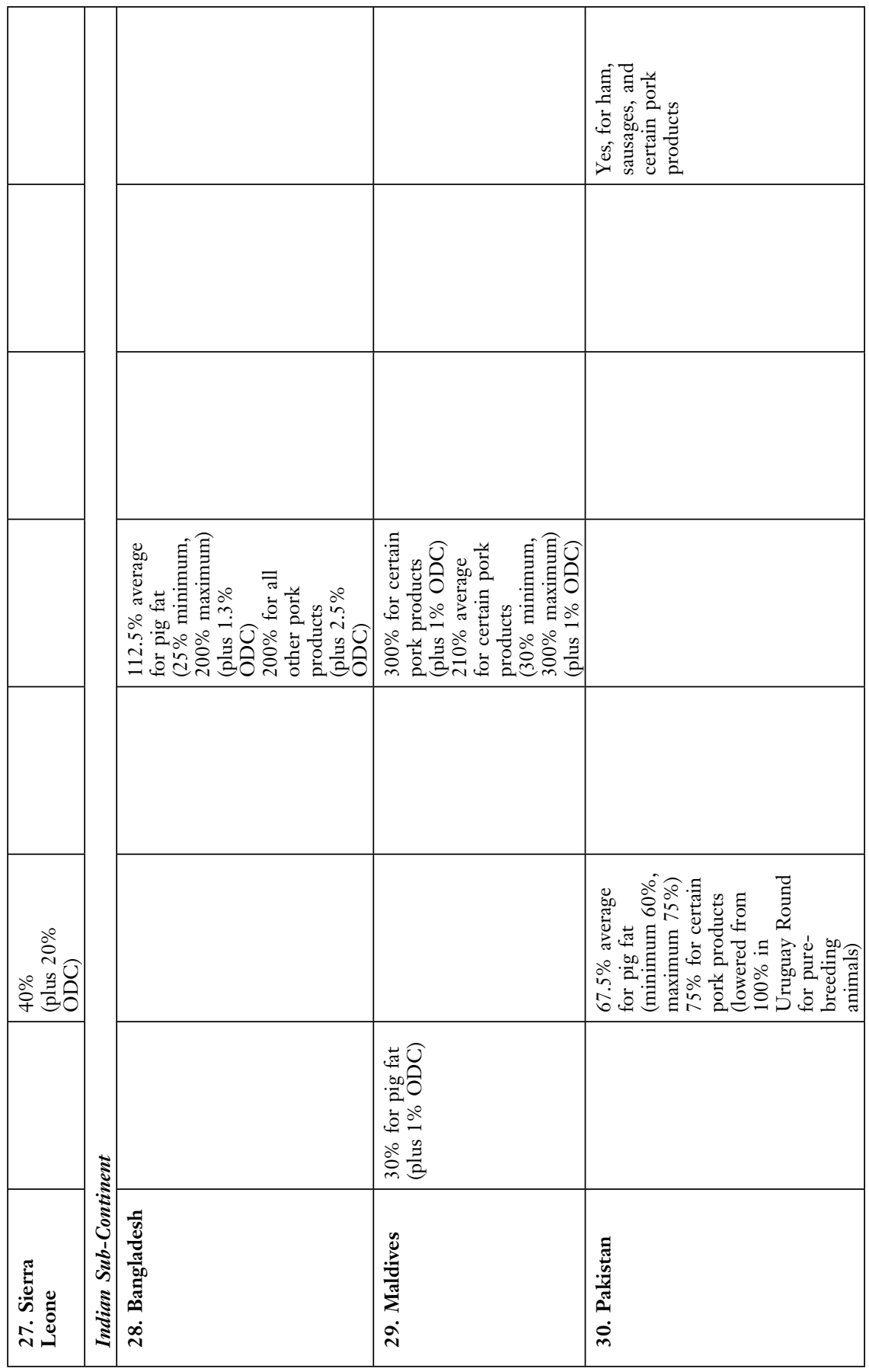

VOL. 47 , NO. 3 


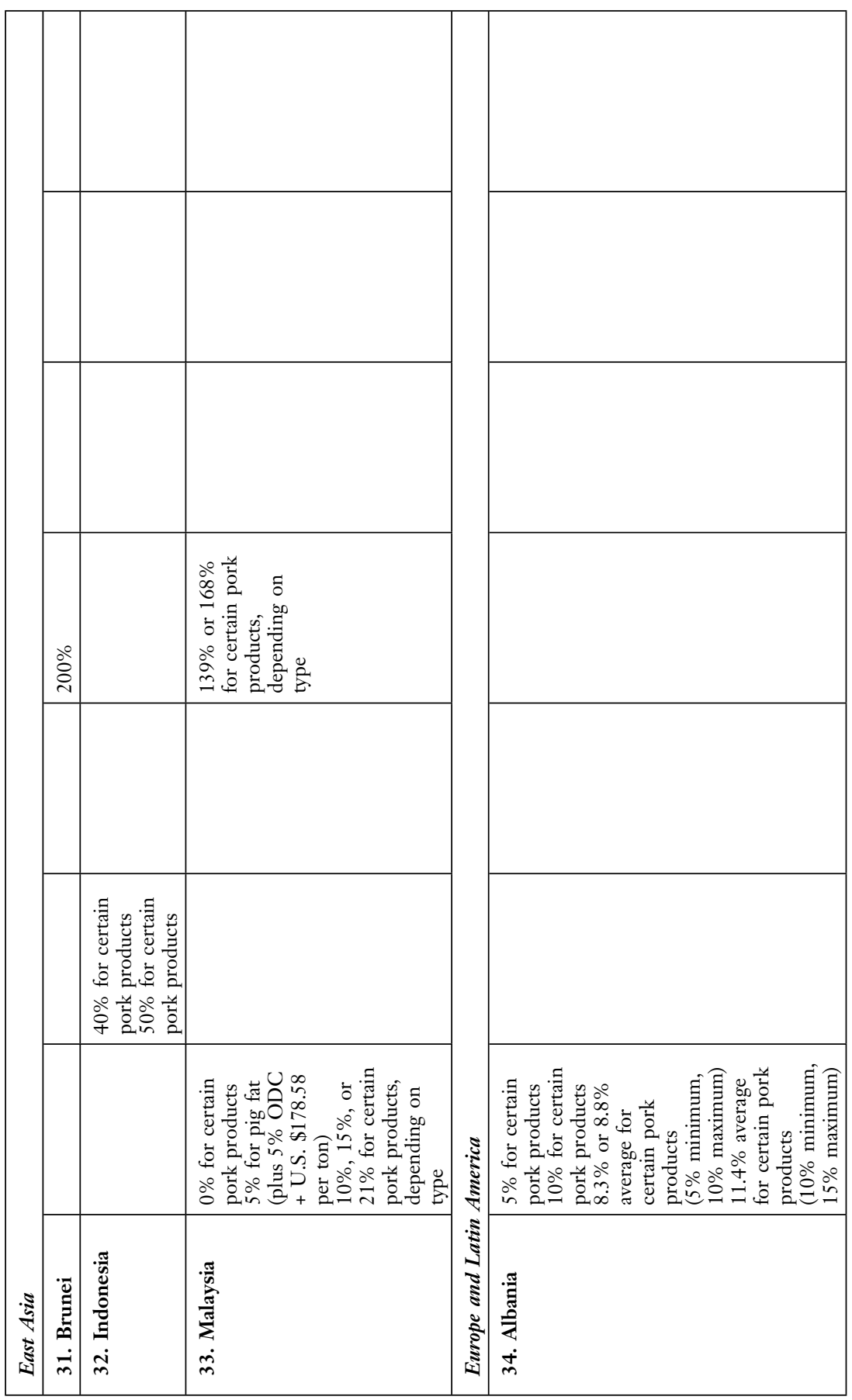

WINTER 2013 
406 THE INTERNATIONAL LAWYER

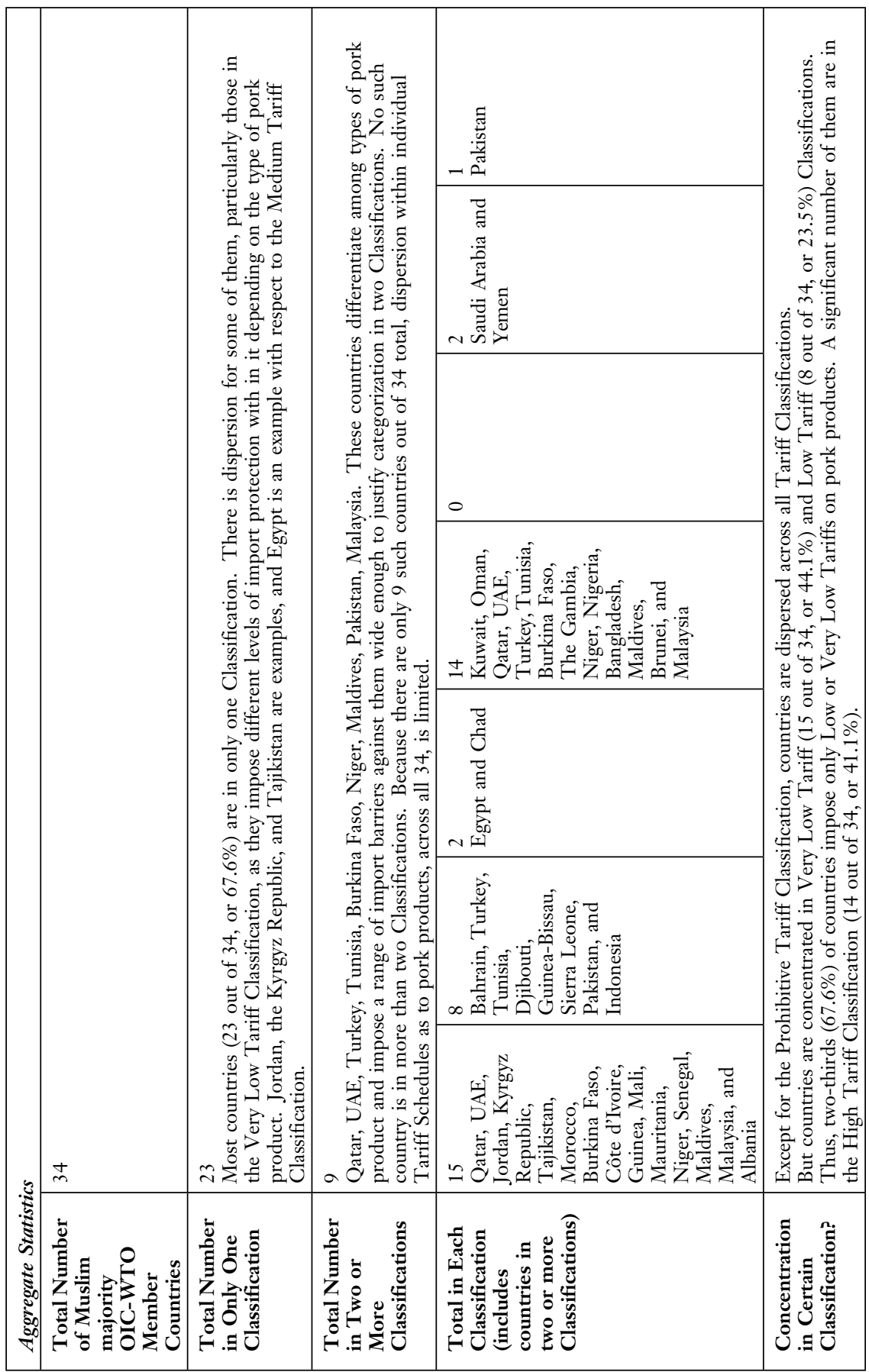

VOL. 47, NO. 3 